\title{
Effects of Organic Wastes on Water Quality from Processing of Oil Shale from the Green River Formation, Colorado, Utah, and Wyoming
}

U.S. GEOLOGICAL. SURVEY PROFESSIONALA A PER 1338

Prepared in cooperation with the U.S. Department of Energy

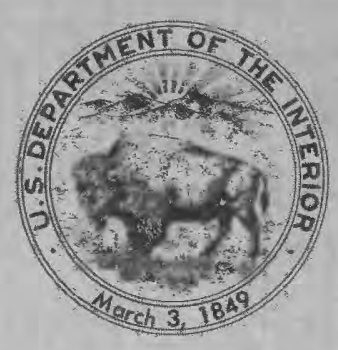


Effects of Organic Wastes on Water Quality from Processing of Oil Shale from the Green River Formation, Colorado, Utah, and Wyoming

By J. A. LEENHEER and T. I. NOYES

U.S. G E O L O G I C A L S U R V E Y P R O F E S S I O N A A L P A P E R

Prepared in cooperation with the U.S. Department of Energy

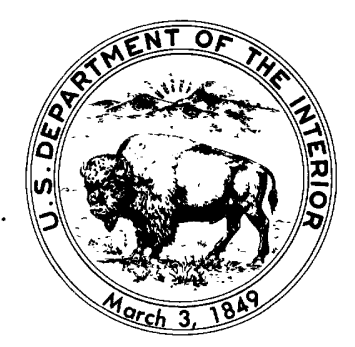




\section{DEPARTMENT OF THE INTERIOR \\ DONALD PAUL HODEL, Secretary}

\section{U.S. GEOLOGICAL SURVEY}

Dallas L. Peck, Director

Library of Congress Cataloging in Publication Data

Leenheer, J. A.

Effects of organic wastes on water quality from processing oil shale from the Green River Formation, Colorado, Utah, and Wyoming.

(Geological survey professional paper ; 1338)

Bibliography: $p$.

Supt. of Does. no.: L 19.16: 1338

1. Oil-shale industry-Waste disposal-Environmental aspects-Wyoming. 2. Oil-shale industry-Waste disposal-Environmental aspects-Colorado. 3. Water quality-Wyoming. 4. Water quality-Colorado. 5. Organic water pollutants. 6. Biodegradation. I. Noyes, T. I. II. Title. III. Title: Green River Formation. IV. Series.

For sale by the

Books and Open-File Reports Section

U.S. Geological Survey

Federal Center

Box 25425

Denver, CO 80225 


\section{CONTENTS}

Page

Abstract Introduction

Purpose and scope

Acknowledgments

Waste-characterization studies

Retort-wastewater characterization

Spent-shale characterization

Retort wastewater-spent shale interactions.

Interactions of individual organic-solute fractions . . . . 11

Synergistic interactions of organic-solute fractions in whole retort wastewater

Comparison of spent shale as a sorbent with granular activated carbon

Subsequent studies of retort wastewater-spent shale interactions

Retort wastewater-soil interactions . . . . . . . . . . . . . . 14

Batch-sorption experiments . . . . . . . . . . . 16

Soil column-sorption experiments . . . . . . . . . . . . 16

Physical and inorganic-constituent interactions ... . 17

Organic-constituent interactions ... . . . . . . . 22

Conclusions about retort wastewater-sorbent interactions

Microbiological degradation of organic solutes in retort wastewater

Effects of bacterial growth on dissolved organic-carbon concentration in Occidental-6 process and gascondensate retort wastewaters
1
2
4
5
5
5
8
11
11

12

13

14
14
16
16
17
22

26
28


28
Microbiological degradation of organic solutes in retort wastewater - Continued

Concurrent independent studies of microbial degradation of organic solutes in retort wastewaters . . . 29

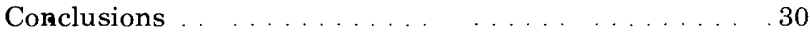

Site studies of effects on water quality from oil-shale retorting

Effects of experimental in-situ reporting on ground water near Rock Springs, Wyoming

Soil survey of in-situ retorting site near Rock Springs, Wyoming

Rio Blanco modified in-situ retort site, Piceance Creek

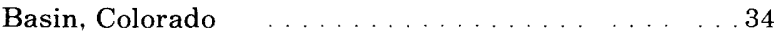

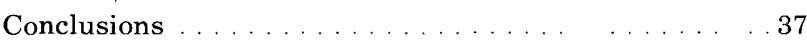

Characterization of natural organic solutes in waters associated with oil shale in the Green River Formation . . . . 39

DOC-fractionation surveys of surface and ground waters.

Isolation and fractionation of natural organic solutes from water ..................... . . . . . . .

Organic-solute characterization of ground water at the Rio Blanco site, Piceance Creek Basin, Colorado . . . . 41

Organic-solute assessment of the White River . . . . . . 44

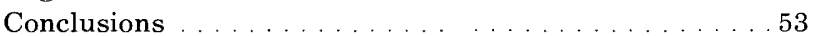

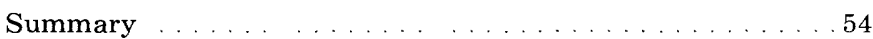

References . . . . . . . . . . . . . . . . . . 55

\section{ILLUSTRATIONS}

FIGURE 1. Map showing principal oil-shale deposits in the Green River Formation, Upper Colorado River Basin ...... 3

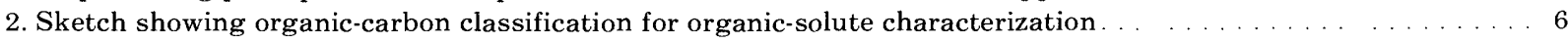

3. Sketch showing analytical methods for dissolved organic-carbon (DOC) fractionation $\ldots \ldots \ldots \ldots$ 4-13. Graphs showing:

4. Sorption isotherms of dissolved organic-carbon fractions in 150-ton retort wastewater on TOSCO-II processed shale. Preparative-scale dissolved organic-carbon fractionation preceded sorption $\ldots \ldots 12$

5. Sorption isotherms of dissolved organic-carbon fractions in 150-ton retort wastewater on TOSCO-II processed shale. Analytical-scale dissolved organic-carbon fractionation followed sorption. . . . . . 13

6. Conceptual model of sorption of organic solutes in retort wastewater during infiltration through a TOSCO-II spent-shale column

7. Sorption of organic solutes in 150-ton retort wastewater on Calgon F-400 activated carbon and TOSCO-II spent shale

8. Sorption isotherm data for TOSCO-II spent shale normalized on elemental-carbon content . . . . . . . 15

9. Extraction isotherms of dissolved organic-carbon fractions from site-9 soil by Omega-9 retort wastewater . . 15

10. Sorption isotherms of dissolved organic-carbon fractions in Omega-9 retort wastewater on site-9 soil . . . 16

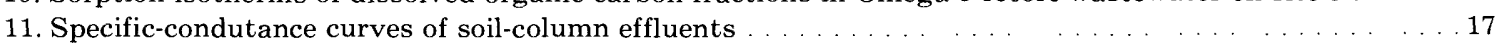

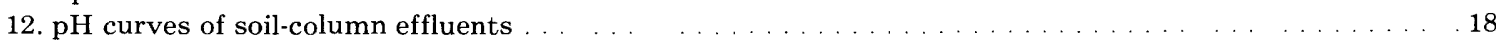

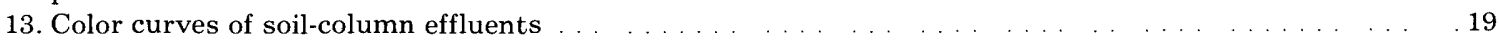

14. Sketch showing soil-retort wastewater reactions . . . . . . . . . . . . . . . . . . . . . . . . . . . 
FIGURES 15-19. Graphs showing: Page

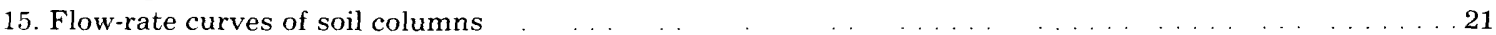

16. Thiocyanate curves for soil-column effluents $\ldots \ldots \ldots \ldots \ldots \ldots$

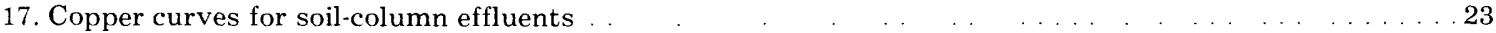

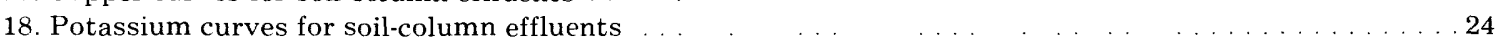

19. Sulfate curves for soil-column effluents $\ldots \ldots \ldots \ldots \ldots \ldots$

20. Chart of soil analyses for ammonia nitrogen $\ldots \ldots \ldots \ldots \ldots \ldots$

21-25. Graphs showing:

21. Dissolved organic-carbon curves for soil-column effluents . $\ldots \ldots \ldots \ldots \ldots \ldots \ldots \ldots$

22. Percentage breakthrough curves for dissolved organic-carbon fractionation of Omega-9 retortwastewater leachate

23. Percentage breakthrough curves for aromatic amines in Omega-9 retort-wastewater leachate $\ldots . . \ldots 29$

24. Growth curve of microorganisms in inoculated flask I, Occidental-6 process retort wastewater ......30

25. Growth curves of microorganisms in inocluated flask II, Occidental-6 process retort wastewater . . . . . 31

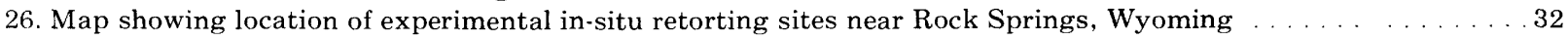

27. Map of wells at the site-9 in-situ retorting experiment near Rock Springs, Wyoming . . . . . . . . . 33

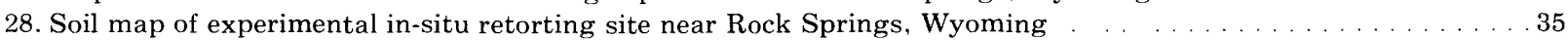

29. Sketch showing flow of water through mobile laboratory $\quad \ldots \ldots \ldots$

30. Sketch showing flow of water through filtration and column-adsorbent system $\ldots \ldots \ldots \ldots$

31. Graph showing infrared spectrum of organic acids of ground water in well D-8 $\ldots \ldots \ldots \ldots$

32. Proton nuclear magnetic resonance (NMR) spectrum of organic acids of ground water in well D-8 $\ldots \ldots \ldots 45$ 33-35. Graphs showing:

33. Infrared spectra of humic acids of the White River; river sampled September $1981 \ldots$. . . . . . . . 49

34. Infrared spectra of strong hydrophobic- and hydrophilic-acid no. 1 fractions of the White River; river sampled September 1981

35. Infrared spectra of acid fractions of the White River; river sampled June $1982 \ldots \ldots \ldots \ldots$

36. Proton nuclear magnetic resonance (NMR) spectra of acid fractions of the White River; river sampled June $1982 \ldots 52$

\section{TABLES}

TABLE 1. Compound groups found in dissolved organic-carbon fractions in oil-shale retort wastewater............. 8

2. Dissolved organic-carbon fractionations of various oil-shale retort wastewaters $\ldots \ldots \ldots \ldots$

3. Organic-solute analyses of Occidental- 6 process and gas-condensate retort wastewaters $\ldots \ldots \ldots \ldots$

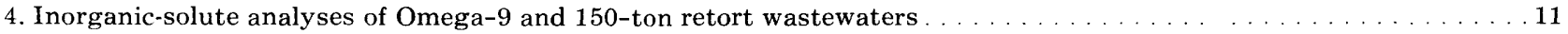

5. Concentration of major inorganic sulfur species in four retort wastewaters $\ldots \ldots \ldots \ldots \ldots \ldots$

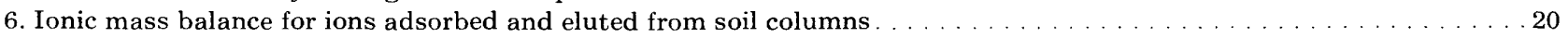

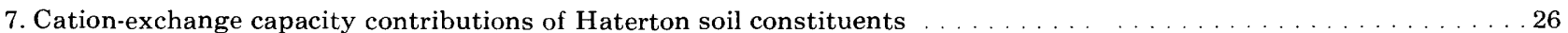

8. Comparison of soil- and liquid-chromatographic-column capacity factors $\left(k^{\prime}\right)$ for aromatic amines . . . . . . . . . 30

9. Dissolved organic-carbon fractionation of sample removed at start of microbial growth in Occidental-6 process retort wastewater, and at 16 and 32 hours after start of experiment $\ldots \ldots \ldots \ldots \ldots \ldots \ldots$

10. Dissolved organic-carbon fractionations of various waters sampled at and near experimental in-situ retorting site 9

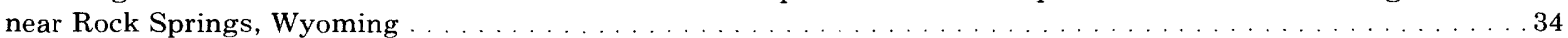

11. Concentration of thiocyanate, thiosulfate and tetrathionate, and ammonia in water from site-9 wells near Rock

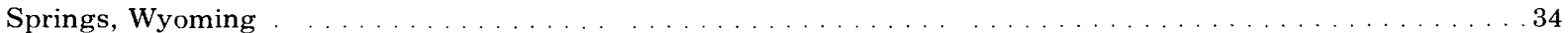

12. Chemical analyses of ground waters sampled May 5, 1981, Rio Blanco retort site, Piceance Creek Basin, Colorado. . 36

13. Inorganic analyses of wastewaters sampled November 19, 1982, from backflooded Rio Blanco retort 1, Piceance Creek Basin, Colorado

14. Organic analyses of wastewaters sampled November 19, 1982, from backflooded Rio Blanco retort 1, Piceance Creek Basin, Colorado

15. Dissolved organic-carbon fractionations of various surface and ground waters associated with oil shale in the Green River Formation

iability of dissolved organic-carbon fractionations for 10 surface waters sampled in the White River Basin, Utah,

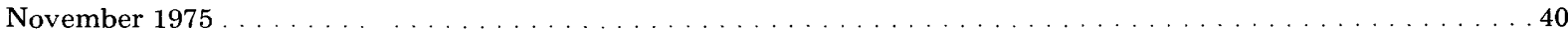

17. Elemental analyses of organic-solute fractions from Rio Blanco well D-8, Piceance Creek Basin, Colorado . . . . 42

18. Quantitative organic structural- and functional-group information on well D-8 organic acids $\ldots \ldots \ldots \ldots$

19. Organic-carbon recoveries from the White River using filtration and column-adsorbent system . . . . . . . . 47

20. Subfractionation of strong hydrophobic- and hydrophilic-acid fractions from the White River, sampled September 1981.47

21. Chemical analyses of organic-solute fractions from the White River, sampled September $1981 \ldots \ldots \ldots \ldots$. . . . . . . 47

22. Elemental analyses of organic-solute fractions isolated from the White River, sampled September $1981 \ldots \ldots \ldots . .48$

23. Chemical and elemental analyses of organic-solute fractions isolated from the White River, sampled June 1982 . . . . 50

24. Quantitative organic structural- and functional-group information on organic-acid fractions from the White River, sampled June 1978 


\section{CONVERSION FACTORS}

\begin{tabular}{|c|c|c|}
\hline Multiply SI unit & By & To obtain inch-pound unit \\
\hline \multicolumn{3}{|c|}{ Length } \\
\hline $\begin{array}{l}\text { micrometer }(\mu \mathrm{m}) \\
\text { millimeter }(\mathrm{mm}) \\
\text { centimeter }(\mathrm{cm}) \\
\text { meter }(\mathrm{m}) \\
\text { kilometer }(\mathrm{km}) \\
\end{array}$ & $\begin{array}{l}0.00003937 \\
0.03937 \\
0.3937 \\
3.281 \\
0.6214 \\
\end{array}$ & $\begin{array}{l}\text { inch (in.) } \\
\text { inch (in.) } \\
\text { inch (in.) } \\
\text { foot (ft) } \\
\text { mile (mi) }\end{array}$ \\
\hline \multicolumn{3}{|c|}{ Volume } \\
\hline $\begin{array}{l}\text { milliliter (mL) } \\
\text { liter (L) } \\
\text { cubic meter }\left(\mathrm{m}^{3}\right)\end{array}$ & $\begin{array}{l}0.03382 \\
0.2642 \\
8.3864 \\
\end{array}$ & $\begin{array}{l}\text { ounce, fluid (oz) } \\
\text { gallon (gal) } \\
\text { barrel, U.S., liquid }\end{array}$ \\
\hline \multicolumn{3}{|c|}{ Mass } \\
\hline $\begin{array}{l}\text { milligrams (mg) } \\
\text { gram (g) } \\
\text { megagram (Mg) }\end{array}$ & $\begin{array}{l}0.00001543 \\
0.03527 \\
1.1023 \\
\end{array}$ & $\begin{array}{l}\text { ounce, avoirdupois }(\mathrm{oz}) \\
\text { ounce, avoirdupois }(\mathrm{oz}) \\
\text { ton, short }(\mathrm{t})\end{array}$ \\
\hline \multicolumn{3}{|c|}{ Flow } \\
\hline liter per minute $(\mathrm{L} / \mathrm{min})$ & 0.2642 & $\begin{array}{l}\text { gallon per minute } \\
\text { (gal/min) }\end{array}$ \\
\hline \multicolumn{3}{|c|}{ Concentration } \\
\hline $\begin{array}{l}\text { milligram per liter }(\mathrm{mg} / \mathrm{L}) \\
\text { microgram per liter }(\mu \mathrm{g} / \mathrm{L}) \\
\text { liter per megagram }(\mathrm{L} / \mathrm{Mg})\end{array}$ & $\begin{array}{l}1.000 \\
0.001 \\
0.2402 \\
\end{array}$ & $\begin{array}{l}\text { part per million (ppm) } \\
\text { part per million }(\mathrm{ppm}) \\
\text { gallon per ton }(\mathrm{gal} / \mathrm{t})\end{array}$ \\
\hline \multicolumn{3}{|c|}{ Temperature } \\
\hline degree Celsius $\left({ }^{\circ} \mathrm{C}\right)$ & $F=9 / 5^{\circ} \mathrm{C}+32$ & degree Fahrenheit $\left({ }^{\circ} \mathrm{F}\right)$ \\
\hline \multicolumn{3}{|c|}{ Specific Conductance } \\
\hline $\begin{array}{l}\text { microsiemens per } \\
\text { centimeter at } 25^{\circ} \\
\text { Celsius }(\mu \mathrm{S} / \mathrm{cm}) \\
\end{array}$ & 1.000 & $\begin{array}{l}\text { micromho per centimeter } \\
\text { at } 25^{\circ} \text { Celsius } \\
\left(\mu \mathrm{mho} / \mathrm{cm} \text { at } 25^{\circ} \mathrm{C}\right)\end{array}$ \\
\hline
\end{tabular}

National Geodetic Vertical Datum of 1929 (NGVD of 1929): A geodetic datum derived from a general adjustment of the first-order level nets of both the United States and Canada, formerly called "mean sea level." NGVD of 1929 is referred to as sea level in this report.

Use of brand and firm names in this report is for identification purposes only and does not constitute endorsement by the U.S. Geological Survey. 


\title{
EFFECTS OF ORGANIC WASTES ON WATER QUALITY FROM PROCESSING OF OIL SHALE FROM THE GREEN RIVER FORMATION, COLORADO, UTAH, AND WYOMING
}

\author{
By J.A. LeENheEr and T.I. NOY ES
}

\section{ABSTRACT}

A series of investigations was conducted during a 6-year research project to determine the nature and effects of organic wastes on water quality from processing oil shale from the Green River Formation. These investigations included retort-wastewater and spent-shale characterization, determination of sorptive characteristics and chemical interactions between soil and spent shale, laboratory studies of microbiological degradation of organic constituents in retort wastewater, onsite studies of water-quality effects resulting from in-situ oil-shale retorting in Wyoming and Colorado, and characterization of natural organic solutes in waters associated with oil shale.

An analytical method, dissolved organic-carbon fractionation analysis, was developed to classify complex organic-solute mixtures found in natural waters and retort wastewaters, into hydrophobic-acid, -base, and -neutral compound groups. Analytical methods were applied to each organic-solute fraction to determine quantitatively the organic solutes in a process retort wastewater and a gas-condensate retort wastewater produced in a modified in-situ oil-shale retort. Fifty percent of the dissolved organic carbon was identified as specific compounds in both retort wastewaters. In the process retort wastewater, 42 percent of the dissolved organic carbon consisted of a homologous series of fatty acids from $\mathrm{C}_{2}$ to $\mathrm{C}_{10}$. Dissolved organic-carbon percentages for the other compound classes were as follows: aliphatic dicarboxylic acids, 1.4 percent; phenols, 2.2 percent; hydroxypyridines, 1.1 percent; and aliphatic amides, 1.2 percent. In the gas-condensate retort wastewater, aromatic amines were most abundant at 19.3 percent of the dissolved organic carbon, followed by phenols (17.8 percent), nitriles (4.3 percent), aliphatic alcohols (3.5 percent), aliphatic ketones (2.4 percent), and lactones ( 1.3 percent). Steamvolatile organic solutes were enriched in the gas-condensate retort wastewater, whereas nonvolatile acids and polyfunctional neutral compounds were predominant organic constituents of the process retort wastewater

Thiosulfate and thiocyanate were major constituents in four retort wastewaters derived from combustion-type processing of oil shale. Thiosulfate was the predominant sulfur species with concentrations ranging from 420 to 2,200 milligrams per liter Thiocyanate concentrations ranged from 24 to 720 milligrams per liter.

The surface chemistry of TOSCO-II spent shale was assessed by determination of its cation- and anion-exchange capacities, determination of surface electrical charge, and spectroscopic studies of its carbonaceous coating after chemical dissolution of the mineral matrix. The cation-exchange capacity 13 milliequivalents per 100 grams) was less than that of most soils, but the anion-exchange capacity ( 1 milliequivalent per 100 grams) was similar to that of soils. The electrical charge of the spent shale is zero at $\mathrm{pH}$ 8.5. The carbonaceous coating on the spent shale primarily is elemental carbon with few oxygenated functional groups.

Batch-equilibrium sorption studies, using TOSCO-II spent shale as the sorbent and combustion-type retort wastewater, determined that the spent shale is a very effective sorbent for organic solutes. The carbonaceous coating of the spent shale had a sorptive capacity equivalent to that of granular activated carbon. Hydrophobic organic solutes had the expected greater sorptive capacities than did hydrophilic organic solutes, but acid solutes had much greater sorptive capacities than normally found on natural sediment sorbents. It is this capacity for acid sorption that makes TOSCOII spent shale an effective sorbent for retort organic wastes codisposed with spent shale.

Chemical and physical interactions of an in-situ oil-shale retort wastewater with a surface soil were investigated. Major findings of this study include an ion exchange-precipitation reaction in which exchangeable calcium in the soil is displaced by ammonium from retort wastewater and precipitated as carbonate by inorganic carbon in retort wastewater. This precipitation process decreases soil permeability. Ammonium was strongly adsorbed from retort wastewater by the soil and was not removed from the soil by subsequent distilled-water leaching and drying. The soil absorbed about 40 percent of organic solutes from retort wastewater in 9.4 pore volumes of leachate; retort wastewater extracted significant quantities of natural fulvic and humic acids from the soil. The soil adsorbed variable quantities of ammonium, arsenic, barium, boron, cadmium, cobalt, copper, fluoride, inorganic carbon, iron, silica, and zinc from retort wastewater. Exchangeable calcium, magnesium, manganese, lithium, potassium, sodium, and strontium were extracted from the soil by ammonium in the retort wastewater. Thiocyanate did not interact and was the best tracer, under these conditions, for retort wastewater. Thiosulfate in retort wastewater was degraded to tetrathionate by passage through the soil columns.

Dissolved organic-carbon fractionation analyses of the soilcolumn effluent determined the following order of increasing affinity of the six organic-compound classes in retort wastewater for soil: hydrophilic neutrals nearly equal to hydrophilic acids, followed by hydrophobic acids, hydrophilic bases, hydrophobic bases, 
and hydrophobic neutrals. Liquid-chromatographic analysis of the aromatic amines in the hydrophobic- and hydrophilic-base fractions showed that the relative order of the rates of migration through the soil column as the same as the order of migration on a reversed-phase, octadecylsilica liquid-chromatographic column, in which the retention of the amine increased with its hydrophobicity.

Microbiological degradation of organic solutes in retort wastewaters was determined to occur preferentially in hydrocarbons and fatty-acid groups of compounds. Aromatic amines did not degrade and they inhibited bacterial growth where their concentrations were significant in a gas-condensate retort wastewater. Thiosulfate was converted to polythionates and sulfate during bacterial growth.

Effects of true in-situ retorting on ground-water quality was studied near Rock Springs, Wyoming, and modified in-situ retorting was studied at the Rio Blanco site in the Piceance Creek Basin, Colorado. True in-situ retorting produced retort wastewater in direct contact with native ground water, but no appreciable migration of contaminants occurred as much as 3 years after the burn because ground-water flow was toward the previously dewatered retort. Ammonia, aromatic amines, and thiocyanate persisted in the contamined ground water, but thiosulfate was quantitatively degraded 1 year after the burn. A first-order soil survey of the retort site at Rock Springs was performed to assess potential interactions between soils and retort wastewaters. Shallow permeable soils occur in the upland regions, whereas relatively impermeable sodic soils occur on the alluvium near watercourses.

Retort wastewaters and gases produced in the modified insitu retort at the Rio Blanco site did not contaminate adjacent ground waters during the burn because of drawdown due to dewatering of the retort and because of negative gas pressure in the retort during the burn. However, ground-water contamination during any future backflooding of the retort after retort abandonment poses the main potential for adverse effects on ground-water quality.

Natural organic solutes isolated from ground water in contact with oil shale in the Green River Formation and from the White River, which receives the discharge from the Piceance Creek Basin being developed for oil-shale resources, were characterized by chemical and physical methods. This characterization included elemental analyses, derivatization of carboxyl, carbonyl, and hydroxyl functional groups, infrared spectroscopy, and proton nuclear magnetic resonance spectroscopy of both derivatized and underivatized fractions. Organic solutes in ground water were distinguished from organic solutes in surface water by the absence of protons associated with hydroxyl, ester, and ether functional groups in ground water compared to surface-water organic solutes. In the White River, polysaccharides and uronic acids were detected in both the humic-acid and hydrophilic-acid fractions, whereas these components were nearly absent in the fulvic-acid fraction. Amide groups were detected predominately in the humic-acid fraction in the White River. Identified biopolymers, as determined by percentages of polysaccharide, uronic acid, and amide moieties, were approximately 10 times as abundant in the White River in September at base flow than in June at peak flow. Seasonal changes in organic solutes in the White River are believed to be due to autochthonous production of organic solutes during base-flow periods in the summer and fall, and allocthonous inputs of terrestrial organi: solutes during peak flow in the spring.

Concentrations of dissolved organic carbon found in natural surface and ground waters ( 1 to 5 milligrams per liter) in the Piceance Creek Basin were 2 to 4 orders of magnitude less than those found in retort wastewaters ( 500 to 500,000 milligrams per liter). Organic contaminants of retort origins primarily are small molecular-weight monomeric compounds, whereas natural organic solutes are complex heterogeneous polymers of biological origin.

\section{INTRODUCTION}

Oil shale in the Green River Formation is the most promising deposit for synthetic-fuels production in the United States. Total oil reserves in known deposits of oil shale yielding more than $18.9 \mathrm{~L}$ of oil equivalent per megagram have been estimated at 636 billion $\mathrm{m}^{3}$ (Duncan and Swanson, 1965) and economically recoverable reserves have been estimated at 48 billion $\mathrm{m}^{3}$ (Donnell and Blair, 1970). Currently (1983), no significant production of shale oil has occurred in the United States; but several oil-shale conversion technologies have been developed and tested, which led to projections by the Office of Technology Assessment of shale-oil production goals of as much as $160,000 \mathrm{~m}^{3}$ per day by 1990 (Sladex and others, 1980). However, given the current economic limitations of oil-shale development, perhaps a more realistic projection is that significant production of shale oil is still 10 to 20 years in the future (Barry, 1981).

The Green River Formation was formed from sediments deposited in interconnected stratified lakes that existed during the Eocene Epoch (Bradley, 1930). These lake sediments consisted of a mixture of partly degraded aquatic organisms that resisted complete decay because of reducing conditions at the lake bottom, mineral matter of fluvial and aeolian origin, and precipitate and evaporite minerals formed during minimum or dry stages of these lakes. These lakes existed for several million years and lake sediments accumulated to thicknesses of as much as $1,100 \mathrm{~m}$. The location of the principal oilshale deposits in the Green River Formation is shown in figure 1.

Oil shale in the Green River Formation ranges from 7 percent organic matter by weight for low-grade oil shale to as much as 35 percent for high-grade oil-shale. The organic matter typically is distributed uniformly through an inorganic marlstone matrix that principally is composed of dolomite and calcite with lesser quantities of plagioclase, illite, quartz, analcite, and orthoclase (Hendrickson, 1975). From 5 to 15 percent of the organic matter is solvent-extractable bitumens, and the remainder is defined as kerogen (Robinson, 1969). Extensive studies of kerogen in the oil shale indicate that it is composed principally of aliphatic cyclic structures with the majority of oxygen present as ester and ether bridges between structural units (Robinson, 1969). When heated to $500^{\circ} \mathrm{C}$, about 80 percent of the organic carbon in the oil shale is converted to shale oil.

The thickest and highest grade oil shale occurs in the Piceance Creek Basin (fig. 1); consequently, the major oil-shale industry probably will develop in Colorado. A lesser development probably will occur in the Uinta Basin of Utah because of accessibility of thinner zones of highgrade oil shale with little or no overburden in limited 


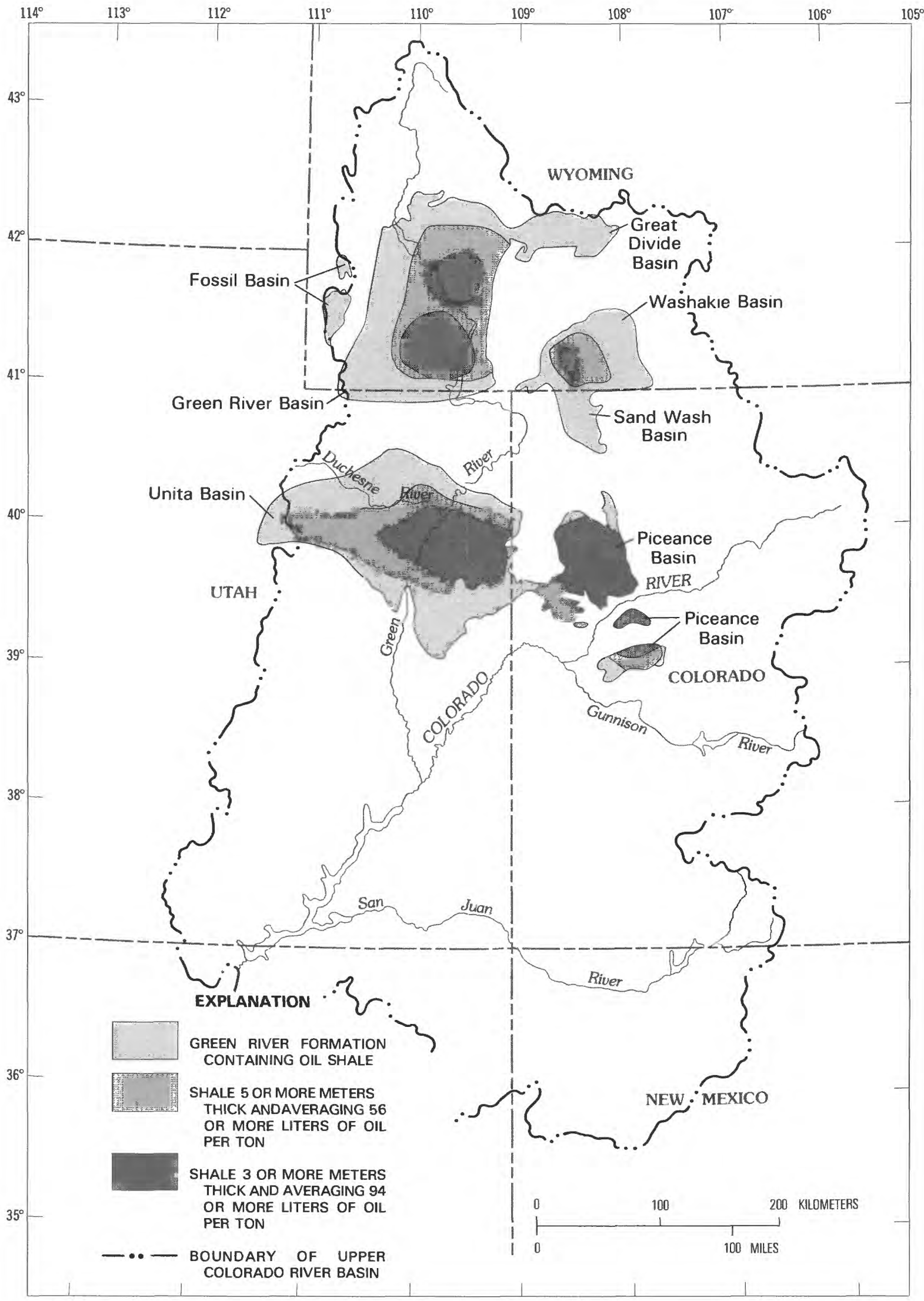

FIGURE 1. - Principal oil-shale deposits in the Green River Formation, Upper Colorado River Basin (modified from Rickert and others, 1979). 
areas. The Colorado, White, and Green Rivers drain these areas and will be affected directly by development of the oil-shale resource. Extensive studies have been made to determine the effects of oil-shale retorting on the hydrology (Weeks and others, 1974) and ground-water quality (Robson and Saulnier, 1980; Slawson, 1980) of the Piceance Creek Basin.

The nature and quantity of solid, liquid, and gaseous wastes produced by retorting of oil shale are very dependent on the type of retorting technology. Summaries of various oil-shale retorting technologies, which have been tested using oil shale from the Green River Formation, are given by Dinneen (1976), Hendrickson (1975), and Yen (1976). As retorting temperatures increase, five types or zones of spent-shale products have been identified in an in-situ retort, each with major chemical and physical property differences (Krause and McLean, 1980). These zones were described by Krause and McLean (1980) as follows:

Zone 1.-Black carbonized shale, thin-bedded, fissile;

Zone 2.-Same as zone 1, except light gray to tan and brown, soft;

Zone 3.--Light gray to tan, very soft, "frothy" appearance due to presence of coalescing vugs, bedding and fissility substantially gone;

Zone 4.-Variegated greens, black, gray, brown, yellow; very porous; fused; clinker-type material, hard; not friable; remnant bedding present, but not pronounced; and

Zone 5.-Buff tan, very soft, similar to zone 3 except vugs absent.

Water-leaching studies of each zone produced $\mathrm{pH}$ values as much as 11.5 for zones 3 and 5 , and dissolvedsolids concentrations as much as $10,000 \mathrm{mg} / \mathrm{L}$ for zone 3 . The presence of free lime in zones 2-5 produced high $\mathrm{pH}$ solutions corrosive to silicate minerals.

Because of the somewhat limited and thus expensive water resources, the semiarid environment, and wastedischarge restrictions where oil shale occurs, it is most likely that the various wastewater streams generated by oil-shale industries will be used for spent-shale disposal after some degree of water treatment. Questions raised by codisposal of wastewater with spent shale include: (1) What is the mobility of wastewater and its dissolved constituents within spent shale; (2) what is the mobility of wastewater and its dissolved constituents within soils and sediments adjacent to spent-shale dumps; (3) what are the chemical, physical, and toxilogical characteristics of the mix of spent shale and wastewater; and (4) how do weathering processes affect spent shalewastewater or soil-wastewater combinations?

In-situ retorting of oil shale poses additional ques- tions regarding water-quality effects: (1) What is the fate and water-quality effects of unrecovered retort wastewater and shale oil; (2) what is the nature of spent shale in an underground retort; (3) what happens to spent shale and ground-water quality during and after backflooding by ground water of a burned in-situ retort; (4) what are the implications of potential physical instability (subsidence) of the retort on ground-water quality; and $(5)$ is a burned retort a potential repository for wastewaters produced by an associated surface-retorting operation?

These questions can only be addressed partly by laboratory and pilot-plant studies; more complete answers to these questions are pending development of a full-scale shale-oil industry. However, research studies of potential water-quality effects related to oil-shale processing should aid both the public and private sectors in designing and selecting a shale-oil technology that is both efficient and environmentally acceptable.

Wastewater from oil-shale processing originates from: retorting operations, shale-oil upgrading operations, airemissions-control and gas-cleaning systems, blowdown from cooling water and boiler systems, mine dewatering, and sanitary-treatment systems. Wastewater from oilshale processing indirectly originates from: leachates from raw-shale storage, retorted-shale disposal areas, runoff from construction and onsite use, and runoff from mining and transport activities (Crawford and others, 1977). Wastewaters from retorting and gas-cleaning operations contain the largest quantities of organic constituents (Jackson and others, 1975). In-situ retorting operations typically generate more wastewater and less surfacedisposed spent shale than do surface retorting operations, but more spent shale per unit volume of shale oil is produced in the subsurface by in-situ retorting because this method is less efficient. Volatile wastewater constituents may be transformed into gaseous wastes by wastewater reuse in the retorting and upgrading operations, or they may be recovered as valuable byproducts such as ammonia and sulfur (Probstein and Gold, 1978).

Approximately 50 percent of the net water consumption of oil-shale technologies using surface retorting has been attributed to spent-shale disposal (Probstein and Gold, 1978), the other 50 percent of the water is used in retorting operations. Water is used in spent-shale disposal for dust control, moisturization to aid in compaction, and for revegetation.

\section{PURPOSE AND SCOPE}

Given the magnitude of the oil-shale resource in the Green River Formation and the potentially significant effects that its development eventually will have on water quality and quantity, the U.S. Geological Survey 
has been conducting water-resources investigations for the past several years on oil-shale development (O. J. Taylor, U.S. Geological Survey, written commun., 1983). The purpose of this report is to summarize the results of a 6-year investigation of the various effects on water quality of organic wastes from processing of oil shale from the Green River Formation.

This report focuses on liquid and solid organic wastes present after oil-shale processing. Organic constituents have received less attention and evaluations in other water-quality studies related to shale-oil processing. These constituents comprise a major part of the wastes because of the organic nature of oil-shale and shaleoil products.

This report will address most of the previously posed questions regarding water-quality effects with respect to organic constituents in wastewater through a discussion of a series of onsite and laboratory investigations. Related chemical and hydrologic studies also will be discussed to provide a more comprehensive assessment of waterquality effects resulting from oil-shale processing.

\section{ACKNOWLEDGMENTS}

The original interest of Lee C. Dutcher and the counsel of John D. Hem were beneficial in establishing goals and providing direction during the initial stages of this study. Robert C. Averett and Robert L. Wershaw provided direction during the middle and latter stages of this study.

The Laramie Energy Technology Center, U.S Department of Energy, Laramie, Wyoming, provided significant financial support from 1977 to 1980 as administered by David S. Farrier and David C. Sheesley. Richard E. Poulson and Larry P. Jackson also provided much encouragement and direction. The wastewater samples from the Omega-9, Occidental-6, and 150-ton retorts were provided by the Laramie Energy Technology Center.

The Oil Shale Corporation (TOSCO) graciously provided the TOSCO-II spent shale, and Geokinetics Corporation cooperated in the sampling of their in-situ spent shale and retort wastewaters. Rio Blanco Oil Shale Corporation was very helpful in the sampling of their modified in-situ mine waters and retort wastewaters.

Professor Patrick McCarthy and Steve Cowling, Colorado School of Mines, and Professor Steven Williams and W. Kennedy Gauger, University of Wyoming, provided critical elements to this study through research grants. Professor Harold Walton, University of Colorado, was advisor to Harold A. Stuber's dissertation research supported by this project.

Special thanks is accorded to Glen A. Miller of the Area Oil Shale Office, Bureau of Land Management, U.S. Department of the Interior, Grand Junction, Colorado, who facilitated cooperative studies with government and industry. Lastly, the major contributions to project research of Harold A. Stuber, U.S. Geological Survey, from 1977 to 1982 need to be acknowledged. His doctoral dissertation on aromatic amine analyses and papers on reduced sulfur species in retort wastewater were major original contributions to the science.

\section{WASTE-CHARACTERIZATION STUDIES}

Most of the water-characterization effort focused on wastewaters from various oil-shale retorts because little was known about their composition at the beginning of this investigation. A more limited investigation was conducted on the chemical and physical properties of the carbonaceous coating on spent oil shale to determine the significance of these coatings with respect to sorptive interactions with retort wastewaters.

\section{RETORT-WASTEWATER CHARACTERIZATION}

At the beginning of this investigation in 1976, the state of knowledge of the properties of retort wastewater was summarized by Jackson and others (1975) and Hendrickson (1975). It then was recognized that ammonium bicarbonate was the primary dissolved constituent accompanied by lesser quantities of sodium, sulfate, and chloride. Significant concentrations of dissolved organic constituents were known to be present, as evidenced by dissolved organic-carbon concentrations, odor, and color. Fatty acids and amines were known to be major organic constituents; phenols were of lesser significance. Major problems in studies of retort-wastewater characterization were the volatility of several dissolved constituents, difficulty in accurate determination of organic-carbon content because of volatile organic constituents in addition to large carbonate and bicarbonate concentrations, lack of solvent extractability of many dissolved organic constituents, and major discrepancies in anioncation balances after a standard, complete waterchemistry analysis.

A major problem was the inadequacy of organic-solute characterization data. A characterization of compound classes of organic solutes was needed because comprehensive analyses of specific organic compounds was not practicable using available methods. Because of the poor solvent extractability of many retort-wastewater organic constituents, a method was developed for compoundclass characterization based on adsorbent-resin fractionations rather than solvent-extraction fractionations.

Accordingly, an organic-compound class fractionation called "dissolved organic-carbon (DOC) fractionation" was developed that could be applied to both oil-shale retort wastewaters and natural waters (Leenheer and Huffman, 1976). The tiered organic-solute classification 


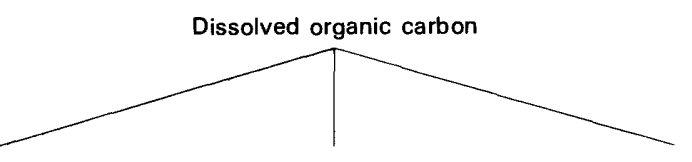

2. Solute-sorption parameters

3. Solute acid - base characteristics based on organic carbon

4. Solute compound classes

5. Specific solute compounds

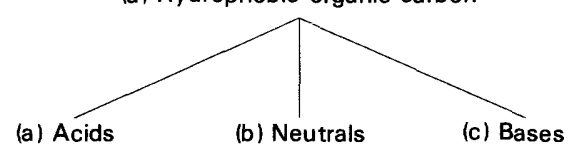

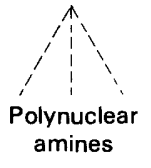

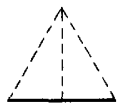

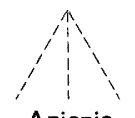
Anionic
detergents
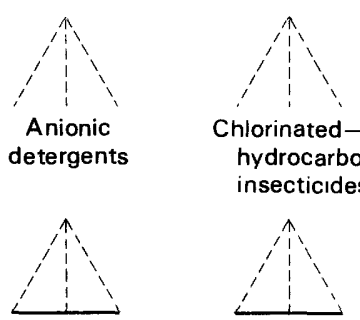

Chlorinatedhydrocarbon insecticides
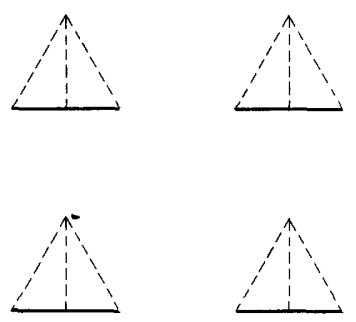

(b) Hydrophilic organic carbon
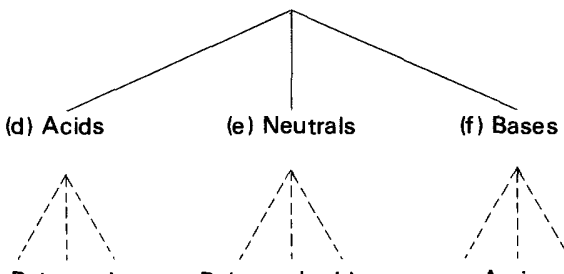

Polyuronic acids

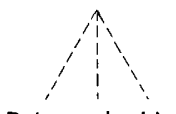

Polysaccharides
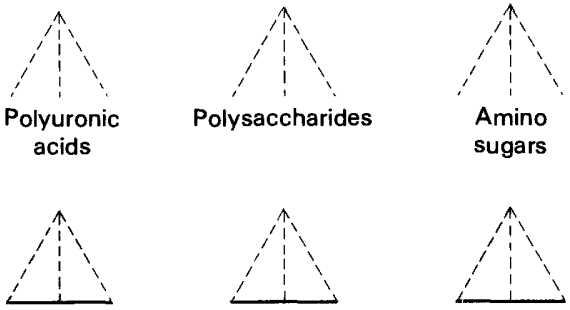

Amino sugars
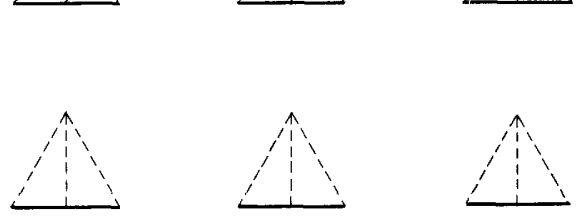

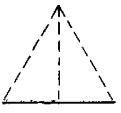

FIGURE 2.-Organic-carbon classification for organic-solute characterization (from Leenheer and Huffman, 1976).

based on DOC fractionation is shown in figure 2 and the standard analytical methods (Leenheer and Huffman, 1979) for DOC fractionation is shown in figure 3.

The organic-compound groups present in oil-shale retort wastewater that are separated in the various stages of DOC fractionation are shown in table 1 , the data are based on a recent study of specific organic compounds in oil-shale retort wastewater (Leenheer and others, 1982). DOC fractionation of seven different oil-shale retort wastewaters are shown in table 2 . Process retort wastewaters typically are found as an emulsion in the raw shale-oil product from a retort, and gas-condensate retort wastewaters are obtained when hot retort vapors cool and condense. Some in-situ retorts do not separate process and gas-condensate retort wastewaters, and some surface retorts that recirculate retort gases back into the retort do not produce gas-condensate retort wastewaters. The volumes and properties of retort wastewaters are dependent on the nature of the retort and the mode of retort operation. The retort-wastewater samples in table 2 were obtained from the Laramie Energy Technology Center, except for the Geokinetics sample obtained from Geokinetics Corporation near Vernal, Utah.

The following conclusions can be drawn from the data in table 2: (1) Retort wastewaters of all types generally have greater organic-base percentages compared to natural waters whose organic-base content is only 5 to 10 percent of the DOC concentration (Stuber and Leenheer, $1978 \mathrm{~b}) ;(2)$ in-situ and gas-condensate retort wastewaters have smaller organic-solute (DOC) concentrations than process retort wastewaters; (3) retort wastewaters, containing significant DOC concentrations, such as the Paraho and Occidental- 6 process retort wastewaters, are greatly enriched in hydrophilic acids, probably because of the greater solubility of this fraction relative to the other fractions; (4) process retort wastewaters in general are enriched in acid solutes, and gas-condensate retort wastewaters are enriched in basic and neutral solutes because of steam-volatility partitioning (Leenheer and others, 1982); and (5) DOC fractionation patterns for the two insitu retort wastewaters indicate these waters are a mixture of process and gas-condensate retort wastewaters.

The Occidental- 6 process and gas-condensate retort wastewaters were fractionated by a preparative DOC fractionation procedure (Leenheer, 1981), and the various fractions were analyzed for specific organic compounds (Leenheer and others, 1982). Results of these analyses are shown in table 3 . Aliphatic-monocarboxylic acids from $\mathrm{C}_{1}$ to $\mathrm{C}_{10}$ are by far the most abundant group of compounds in the process retort wastewater, but they only constitute 0.36 percent of the $\mathrm{DOC}$ in the gascondensate retort wastewater, because ionization of carboxyl groups at $\mathrm{pH} 8.6$ of retort wastewater limits the volatility of aliphatic-monocarboxylic acids. Other organic components detected in lesser quantities in process retort wastewater include aliphatic-dicarboxylic acids, aromatic-carboxylic acids, thiocyanate, phenols, aromatic amines, hydroxypyridinines, aliphatic amides, nitriles, aliphatic ketones, and lactones.

Organic solutes in the gas-condensate retort wastewater 

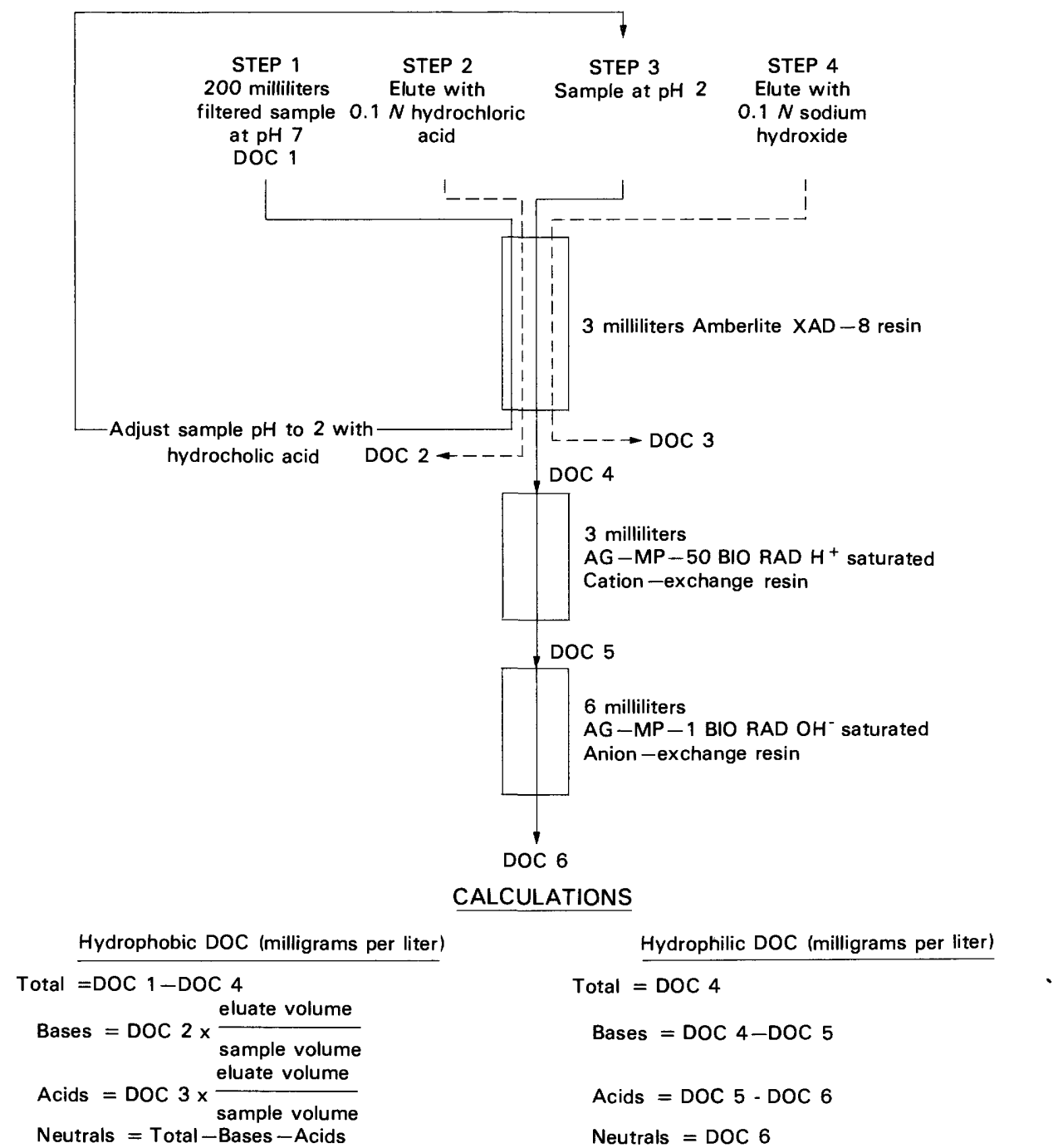

FIGURE 3.-Analytical methods for dissolved organic-carbon (DOC) fractionation (from Leenheer and Huffman, 1979).

consist mainly of phenols and aromatic amines with lesser quantities of nitriles, aliphatic alcohols, aliphatic ketones, and lactones. Aromatic amines are mainly responsible for the disagreeable odor of retort wastewaters, and the quinolines found in this compound group are some of the most toxic organic constituents found in retort wastewaters. Generally speaking, monofunctional organic compounds found in retort wastewaters are limited to 10 carbons or less, because greater molecular-weight components, being more insoluble in water, partition into shale oil produced with retort wastewaters. Specific information on low solubility, solvent-extractable organic compounds in Occidental- 6 retort wastewaters is presented in a report by Raphaelian and Harrison (1981).

A second area of research in retort-wastewater characterization is the nature of dissolved sulfur species. Inorganic analyses of major constituents in Omega-9 and 150-ton retort wastewaters are shown in table 4. Comparison of the total sulfur concentration in Omega-9 retort wastewater with the sulfate indicated significant quantities of dissolved sulfur species other than sulfate. Acidification of retort wastewaters was found to produce elemental sulfur, which is characteristic of certain reduced sulfur species. Four retort wastewaters were tested for sulfide, polysulfide, sulfite, thiosulfate, polythionate, and thiocyanate anions (Stuber and others, 1978). Most of the missing sulfur was accounted for by thiosulfate, tetrathionate, and thiocyanate, as shown by data in table 5 . Discovery of these reduced sulfur species prompted other investigators, such as Fox and others (1978), to conduct comprehensive inorganic analyses resulting in complete anion-cation balances. Recent research (Wallace and others, 1981) has shown that most of reduced sulfur in retort wastewater is present initially as sulfide that 
TABLE 1.- Compound groups found in dissolved organic-carbon fractions in oil-shale retort wastewater

\begin{tabular}{lc}
\hline Organic-carbon fraction & Compound group \\
\hline $\begin{array}{l}\text { Hydrophobic organic carbon } \\
\text { Bases: }\end{array}$ & One- and two-ring aromatic amines except \\
& pyridine. \\
Aliphatic monocarboxylic carboxylic acids \\
of 5 to 11 carbons, 1-ring aromatic \\
carboxylic acids, 8 to 11 carbon \\
aliphatic dicarboxylic acids and \\
phenols. \\
Aliphatic and aromatic hydrocarbons, \\
aliphatic amides and alcohols greater \\
than five carbons, aliphatic ketones and \\
nitriles greater than four carbons, \\
aromatic nitriles and amides, thiophenes, \\
thiazoles, furans, pyrroles, lactones. \\
Neutrals: \\
Hydroxypyridines, pyridine carboxylic \\
acids, aliphatic amines, pyridine. \\
Aliphatic monocarboxylic acids of one to \\
five carbons, aliphatic dicarboxylic \\
acids of two to seven carbons, \\
thiocyanate. \\
Aliphatic amides and alcohols of one to \\
four carbons, aliphatic nitriles, and \\
aldehydes of two to three carbons, \\
acetone, urea. \\
\hline
\end{tabular}

degrades during refrigerated storage at the rate of 20 percent per day to thiosulfate and polythionates. Thiosulfate degrades at a more moderate rate to polythionates and eventually sulfate (Stuber and others, 1978; Leenheer and others, 1981).

\section{SPENT-SHALE CHARACTERIZATION}

The nature of the carbonaceous coating on spent shale, resulting when shale is retorted at low temperature, was the topic of a Master's thesis by Cowling (1979). This research, funded by the U.S. Geological Survey, was conducted to evaluate TOSCO-II spent shale as a sorbent for retort wastewaters. Specialized procedures had to be developed to determine exchange capacities and $\mathrm{pH}$ of the zero point of charge because of the calcareous and gypsiferous nature of spent shale.

Ion-exchange procedures were developed that omitted the wash step between the ionic-saturation steps and ionic-replacement steps to minimize dissolution of sparingly soluble minerals in the spent shale. Isopropanol was used as a tracer to correct for the volume of solution remaining in the moist shale after the saturation step. Cation-exchange capacity determinations varied between 2 and $3 \mathrm{meq} / 100 \mathrm{~g}$ (milliequivalents per $100 \mathrm{grams}$ ), and

TABLE 2.-Dissolved organic-carbon fractionations of various oil-shale retort wastewaters [in percent]

\begin{tabular}{|c|c|c|c|c|c|c|c|c|}
\hline Fraction & $\begin{array}{l}\text { Omega- }^{1} \\
\text { retort } \\
\text { wastewater } \\
\text { (in-situ } \\
\text { retort) }\end{array}$ & $\begin{array}{l}\text { Geokinetics } \\
\text { retort } \\
\text { wastewater } \\
\text { (in-situ } \\
\text { retort) }\end{array}$ & $\begin{array}{l}\text { 150-ton }{ }^{1} \\
\text { retort } \\
\text { wastewater } \\
\text { (simulated } \\
\text { in-situ } \\
\text { surface } \\
\text { retort) }\end{array}$ & $\begin{array}{l}10 \text {-ton }{ }^{1} \\
\text { retort } \\
\text { wastewater } \\
\text { (simulated } \\
\text { in-situ } \\
\text { surface } \\
\text { retort) }\end{array}$ & $\begin{array}{l}\text { Occidental-6 } \\
\text { process } \\
\text { retort } \\
\text { wastewater } \\
\text { (modified } \\
\text { in-situ } \\
\text { retort) }\end{array}$ & $\begin{array}{l}\text { Occidenta1-6 } \\
\text { gas-condensate } \\
\text { retort } \\
\text { wastewater } \\
\text { (modified } \\
\text { in-situ } \\
\text { retort) }\end{array}$ & $\begin{array}{l}\text { Paraho }^{1} \\
\text { process } \\
\text { retort } \\
\text { wastewater } \\
\text { (surface } \\
\text { retort) }\end{array}$ & $\begin{array}{l}\text { Natural surface } \\
\text { water, White } \\
\text { River Basin, } \\
\text { Utah } \\
\text { (means of } \\
10 \text { samples) }\end{array}$ \\
\hline $\begin{array}{l}\text { Total hydrophobic } \\
\text { solutes. }\end{array}$ & 49 & 60 & 55 & 36 & 44 & 68 & 16 & 43 \\
\hline $\begin{array}{l}\text { Total hydrophilic } \\
\text { solutes. }\end{array}$ & 51 & 40 & 45 & 64 & 56 & 32 & 84 & 57 \\
\hline Hydrophobic bases. & 13 & 12 & 9 & 6 & 5 & 24 & 2 & .3 \\
\hline Hydrophobic acids. & 19 & 21 & 26 & 16 & 28 & 19 & 10 & 36 \\
\hline $\begin{array}{l}\text { Hydrophobic } \\
\text { neutrals. }\end{array}$ & 17 & 27 & 20 & 14 & 11 & 25 & 4 & 7 \\
\hline Hydrophilic bases. & 12 & 10 & 15 & 12 & 9 & 12 & 5 & 7 \\
\hline Hydrophilic acids. & 29 & 13 & 15 & 40 & 39 & 9 & 73 & 40 \\
\hline $\begin{array}{c}\text { Hydrophilic } \\
\text { neutrals. }\end{array}$ & 10 & 17 & 15 & 12 & 8 & 11 & 6 & 10 \\
\hline Total bases. & 25 & 22 & 24 & 18 & 14 & 36 & 7 & 7 \\
\hline Total acids. & 48 & 34 & 41 & 56 & 67 & 28 & 83 & 76 \\
\hline Total neutrals. & 27 & 44 & 35 & 26 & 19 & 36 & 10 & 17 \\
\hline $\begin{array}{l}\text { Dissolved organic } \\
\text { carbon, in } \\
\text { milligrams per } \\
\text { liter. }\end{array}$ & 977 & 980 & 5,140 & 2,940 & 3,000 & 790 & 54,800 & 7.3 \\
\hline
\end{tabular}

1Obtained from Laramie Energy Technology Center, U.S. Department of Energy, Laramie, Wyoming.

2obtained from Geokinetics Corp., Vernal, Utah. 


\section{WASTE-CHARACTERIZATION STUDIES}

TABLE 3.-Organic-solute analyses of Occidental-6 process and gas-condensate retort wastewaters

[DOC, dissolved organic carbon; mg/L, milligrams per liter;--, no data; HPI-A, hydrophilic acid; HPO-A, hydrophobic acid; HPI-B, hydrophilic base; HPO-B, hydrophobic base, HPI-N, hydrophilic neutral; HPO-N, hydrophobic neutral; NA, not anlayzed, ND, not detected]

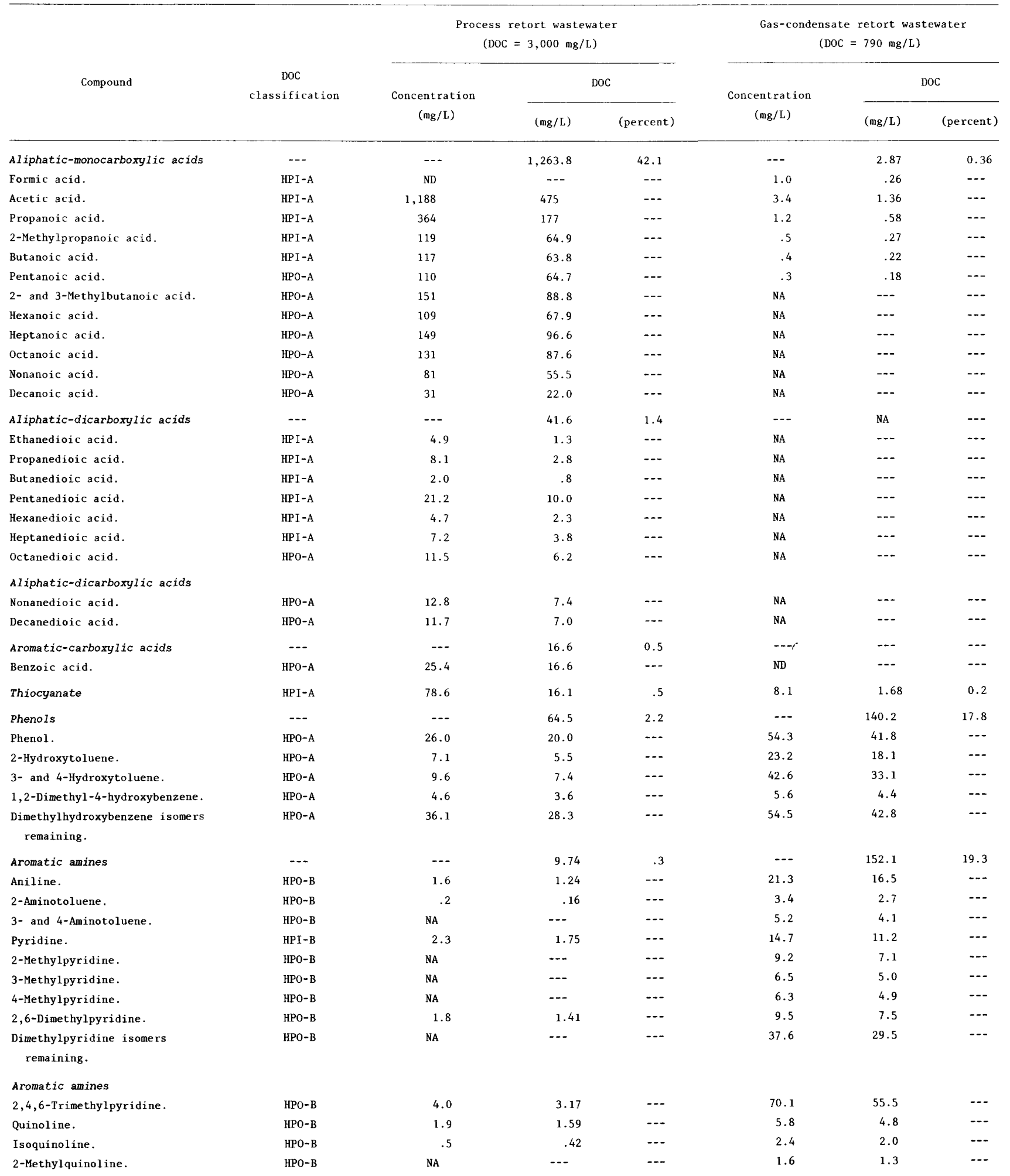


TABLE 3.-Organic-solute analyses of Occidental-6 process and gas-condensate retort wastewaters-Continued

\begin{tabular}{|c|c|c|c|c|c|c|c|}
\hline \multirow{3}{*}{ Compound } & \multirow{3}{*}{$\begin{array}{c}\text { DOC } \\
\text { classification }\end{array}$} & \multicolumn{3}{|c|}{$\begin{array}{l}\text { Process retort wastewater } \\
(\text { DOC }=3,000 \mathrm{mg} / \mathrm{L})\end{array}$} & \multicolumn{3}{|c|}{$\begin{array}{c}\text { Gas-condensate retort wastewater } \\
(\mathrm{DOC}=790 \mathrm{mg} / \mathrm{L})\end{array}$} \\
\hline & & \multirow{2}{*}{$\begin{array}{c}\text { Concentration } \\
(\mathrm{mg} / \mathrm{L})\end{array}$} & \multicolumn{2}{|c|}{ DOC } & \multirow{2}{*}{$\begin{array}{l}\text { Concentration } \\
\qquad(\mathrm{mg} / \mathrm{L})\end{array}$} & \multicolumn{2}{|c|}{ Doc } \\
\hline & & & $(m g / L)$ & (percent) & & $(\mathrm{mg} / \mathrm{L})$ & (percent) \\
\hline Aliphatic amines ${ }^{1}$ & $\cdots$ & --- &.-- & --- & --- & --- & --- \\
\hline Methylamine. & HPI-B & 1.8 & -- & $\cdots$ & 1.8 & -- & $\cdots$ \\
\hline Ethylamine. & HPI-B & 2.4 & --- & $-\cdot$ & 3.0 & --- & --- \\
\hline Hydroxypyridines & $\cdots$ & -- & 31.5 & 1.1 & ND & -- & --- \\
\hline 2-Hydroxypyridine. & HPI-B & 13.6 & 8.6 & --- & ND & -- & -- \\
\hline 3-Hydroxypyridine. & HPI-B & 5.6 & 3.5 & $\cdots$ & $\mathrm{ND}$ & $\cdots$ & $\cdots$ \\
\hline 4-Hydroxypyridine. & HPI-B & 4.0 & 2.5 & --- & ND & $\cdots$ & -.. \\
\hline 2-Hydroxy-6-methylpyridine. & HPI-B & 25.6 & 16.9 & -- & ND & -- & $-\cdot$ \\
\hline Pyridinecarboxylic acids & -.. & --- & .70 & Trace & $\mathrm{NA}$ & --- & --- \\
\hline 2-Pyridinecarboxylic acid. & HPI-B & .3 & .18 & $\cdots$ & $\mathrm{NA}$ & --- & --- \\
\hline 3-Pyridinecarboxylic acid. & HPI-B & .5 & .29 & --- & NA & -- & $\cdots$ \\
\hline 4-Pyridinecarboxylic acid. & HPI-B & .4 & .23 & $\cdots$ & NA & -- & --- \\
\hline Aliphatic amides & $\cdots$ & --- & 38.5 & 1.2 & -- & 2.46 & 0.3 \\
\hline Formamide. & HPI-N & ND & --- & --- & 2.0 & .53 & --- \\
\hline Acetamide. & HPI-N & 52.7 & 21.4 & $\cdots$ & 4.0 & 1.63 & $\cdots$ \\
\hline Propionamide. & HPI-N & 23.2 & 11.4 & $\cdots$ & .6 & .30 & $\cdots$ \\
\hline Butyramide. & HPI-N & 2.0 & 1.1 & $\cdots$ & ND & -- & --- \\
\hline Urea. & HPI $-\mathrm{N}$ & 22.8 & 4.6 & -- & $\mathrm{NA}$ & --- & $\cdots$ \\
\hline Nitriles & $\ldots$ & --- & 3.4 & 0.1 & --- & 34.3 & 4.3 \\
\hline Acetonitrile. & HPI-N & 5.8 & 3.4 & -- & 38.9 & 22.8 & -- \\
\hline Propionitrile. & HPI-N & ND & -- & -- & 8.5 & 5.6 & $\cdots$ \\
\hline Isobutyronitrile. & HPO-N & ND & -- & -- & 2.3 & 1.6 & --- \\
\hline Butyronitrile. & HPO-N & ND & -- & $\cdots$ & 2.5 & 1.7 & -.- \\
\hline Valeronitrile. & HP0-N & ND & $\cdots$ & $\cdots$ & .6 & .4 & $\cdots$ \\
\hline Benzonitrile. & HPO-N & $\mathrm{ND}$ & $\cdots$ & -- & 2.7 & 2.2 & --- \\
\hline Aliphatic alcohols & $\cdots$ & --- & 1.5 & Trace & --- & 27.26 & 3.5 \\
\hline Methanol. & HPI-N & ND & $\cdots$ & -- & 3.4 & 1.28 & --- \\
\hline Ethanol. & HPI-N & ND & $-\cdot$ & --- & 2.8 & 1.46 & $\cdots$ \\
\hline Propanol. & HPI-N & ND & $\ldots$ & -.. & .2 & .12 & --- \\
\hline Isopropanol. & HPI $-\mathrm{N}$ & 2.5 & 1.5 & $\ldots$ & 26.6 & 16.0 & -- \\
\hline sec-Butylalcohol. & HPI-N & ND & --- & $\cdots$ & 13.0 & 8.4 & $\cdots$ \\
\hline Aliphatic ketones & --- & $\ldots$ & 2.42 & .1 & -.- & 20.7 & 2.6 \\
\hline Acetone. & HPI-N & 3.9 & 2.42 & -- & 19.5 & 12.1 & $\cdots$ \\
\hline 2-Butanone. & HPO-N & --- &.- & -- & 10.2 & 7.9 & -- \\
\hline 2-Pentanone. & HPO-N & $\cdots$ & $\cdots$ & -- & .9 & .7 & --- \\
\hline Aliphatic aldehydes &.-- &.-- & 1.31 & Trace & --- & -- & --- \\
\hline Acetaldehyde. & HPI-N & 2.4 & 1.31 & $\cdots$ & ND & --- & --- \\
\hline Lactones &.-- & --- & 16.7 & .6 & -- & 12.2 & 1.3 \\
\hline$\gamma$-Butyrolactone. & HPO-N & 13.7 & 7.6 & --- & 9.6 & 5.4 & $\cdots$ \\
\hline$\gamma$-Valerolactone. & HPO-N & 15.2 & 9.1 &.-- & 11.3 & 6.8 & $\cdots$ \\
\hline Pyrrols & HPO-N & ND & -.- & --- & 4.9 & 3.56 & .4 \\
\hline Identified DOC & ... & -.- & $1,508.4$ & 50.3 & --- & 397.3 & 50.3 \\
\hline
\end{tabular}

${ }^{1}$ Tentative data not included in carbon balance.

anion-exchange capacities were less than $1 \mathrm{meq} / 100 \mathrm{~g}$ at ambient $\mathrm{pH}$ of 8.5 to 9.0 for TOSCO-II spent shale. The cation-exchange capacity of a soil developed on oil shale in the Green River Formation ranged from 7 to 10 meq/100 at ambient $\mathrm{pH}$. Anion-exchange capacities were undetectable.

Adsorption of anionic and cationic dyes of fixed charge as a function of $\mathrm{pH}$ was a new procedure developed to measure $\mathrm{pH}$ of the zero point of charge. The $\mathrm{pH}$ of the zero point of charge of TOSCO-II spent shale was found to be 8.5. Changes in cation-exchange capacity on destruction of the carbonaceous coating by oxygen-plasma ashing and destruction of the inorganic matrix by hydrochloric-hydrofluoric acids indicated that approximately 
TABLE 4.-Inorganic-solute analyses of Omega-9 and 150-ton retort wastewaters

[Data in milligrams per liter except as indicated]

\begin{tabular}{|c|c|c|}
\hline $\begin{array}{l}\text { Property or } \\
\text { constituent }\end{array}$ & $\begin{array}{c}\text { Omega-9 retort wastewater } \\
\text { (in-situ retort) }\end{array}$ & $\begin{array}{l}\text { 150-ton retort wastewater, } \\
\text { barrel } 66, \text { run } 13 \\
\text { (simulated in-situ } \\
\text { surface retort) }\end{array}$ \\
\hline $\mathrm{pH}$ & 8.5 & 8.6 \\
\hline $\begin{array}{l}\text { Specific conductance } \\
\text { (microsiemens per cen } \\
\text { at } 25^{\circ} \text { Celsius) }\end{array}$ & ntimeter & 48,000 \\
\hline Calcium & 8 & 4 \\
\hline Magnesium & 12 & 16 \\
\hline Sodium & 4,100 & 188 \\
\hline Potassium & 43 & 24 \\
\hline Bicarbonate & 15,100 & 33,400 \\
\hline Carbonate & 2,100 & 14,900 \\
\hline Chloride & 3,900 & 2,800 \\
\hline Fluoride & 56 & 12 \\
\hline Sulfate & 1,400 & 1,340 \\
\hline Total sulfur & 2,300 & $\cdots$ \\
\hline Ammonium as nitrogen & 3,800 & --- \\
\hline Total kjeldahl nitrogen & 4,000 & 18,000 \\
\hline
\end{tabular}

50 to 70 percent of the cation-exchange capacity was associated with the carbonaceous coating on the spent shale.

The carbonaceous coating ( 4.5 percent by weight) of TOSCO-II spent shale was examined by X-ray diffraction, $\mathrm{X}$-ray fluorescence, electron microscopy, and infrared spectroscopy as the inorganic shale matrix was degraded successively through a series of acid treatments. The carbonaceous coating was found to be virtually elemental carbon with a trace of carbonyl functional groups.

The minimal exchange-capacity values, the $\mathrm{pH}$ of the zero point of charge near environmental $\mathrm{pH}$ levels, and the general lack of oxygen-containing functional groups in the carbonaceous coating all indicate that TOSCO-II spent shale is a neutral adsorbent that should have only slight degrees of ionic and polar interactions with dissolved constituents in water. The predominant sorptive interaction should be hydrophobic interactions on the elemental carbon coating. Because of the relatively large surface area of the silt-sized TOSCO-II spent shale, coupled with an appreciable elemental-carbon content, this spent shale should be a good sorbent for hydrophobic solutes in wastewaters codisposed with the spent shale.

\section{RETORT WASTEWATER-SPENT SHALE INTERACTIONS}

The topic of retort wastewater-spent shale interactions is an issue of considerable importance because several technologies have proposed codisposal of retort wastewater and spent shale. Currently, the U.S. Environmental Protection agency does not allow codisposal because: (1) There is concern that two separate disposal problems may be combined into a potentially more serious disposal problem; and (2) there is a lack of data pertaining to the environmental acceptability of codisposal (Stanwood and others, 1980). To obtain information relevant to the above concerns about codisposal, a series of batch-type adsorption experiments were conducted with the TOSCO-II spent shale (characterized by Cowling, 1979 ) as the sorbent and organic solutes in retort wastewater (obtained from the 150-ton retort, barrel 66, run 13, Laramie Energy Technology Center) as sorbates.

\section{INTERACTIONS OF INDIVIDUAL ORGANIC-SOLUTE FRACTIONS}

The complex organic-solute mixture in retort wastewater was simplified for sorption studies by generating more homogeneous compound groups by the DOC fractionation procedure. Because the DOC fractionation procedure is based on sorptive interactions, it also served as an interpretive tool for assignment of sorption mechanisms of the individual fractions on spent shale. The experimental design of the first set of experiments was

TABLE 5.-Concentration of major inorganic sulfur species in four retort wastewaters [Data in milligrams per liter]

\begin{tabular}{lccccc} 
Sample & $\begin{array}{c}\text { Total } \\
\text { sulfur }\end{array}$ & $\begin{array}{c}\text { Sulfate as } \\
\text { sulfur }\end{array}$ & $\begin{array}{c}\text { Thiosulfate } \\
\text { as sulfur }\end{array}$ & $\begin{array}{c}\text { Tetrathionate } \\
\text { as sulfur }\end{array}$ & $\begin{array}{c}\text { Thiocyanate } \\
\text { as sulfur }\end{array}$ \\
\hline $\begin{array}{l}\text { Omega-9 retort wastewater } \\
\text { 150-ton retort wastewater }\end{array}$ & 2,300 & 680 & 1,270 & 80 & 74 \\
$\begin{array}{l}\text { Geokinetics gas-condensate } \\
\text { retort wastewater }\end{array}$ & 1,290 & 390 & 525 & $<5$ & 405 \\
$\begin{array}{l}\text { Geokinetics process retort } \\
\text { wastewater }\end{array}$ & 690 & 27 & 240 & $<5$ & 52 \\
\hline
\end{tabular}


to test whether the adsorption of the various individual solute fractions on spent shale would sum to the sorption of all organic components in the unfractionated retort wastewater. Lack of summation would indicate synergistic solute interactions that affect sorption.

A preparative-scale DOC fractionation was conducted on 150-ton retort wastewater to generate gram quantities of the various fractions; the fractions were redissolved in a synthetic inorganic retort-wastewater matrix at concentrations equivalent to retort-wastewater concentrations, and varying quantities of spent shale were added and equilibrated in stirred systems contained in a $25^{\circ} \mathrm{C}$ water bath (Stuber and Leenheer, 1978a; Leenheer, 1980 ). The quantity of sorbent was varied rather than the sorbate concentration to better observe the chromatographic effect resulting from differential affinities of organic-solute fractions for spent shale. Results of this first set of sorption experiments are graphed in the sorptionisotherm data in figure 4.

The unfractionated sorption isotherm did not coincide with the sum of the organic-solute-fraction sorption isotherms, indicating that both positive and negative synergistic interactions occurred. Secondly, the exponential increase of the unfractioned sorption isotherm beginning near 70 percent of initial concentration probably is related to preferential sorption of the hydrophobic-neutral fraction that could not be tested as an individual fraction because of its solubility in water in the absence of the other fractions. As expected, the hydrophobic fractions had greater sorptive capacities than the hydrophilic fractions because of hydrophobic sorption on the elemental carbon of the spent shale; however, the greater sorptive capacities of the acid fractions than the base fractions were unexpected, because cation-exchange capacities, although small, previously were found to exceed anionexchange capacities for this spent-shale sorbent by factors of 2 to 3 .

\section{SYNERGISTIC INTERACTIÓNS OF ORGANIC-SOLUTE FRACTIONS IN WHOLE RETORT WASTEWATER}

To obtain better insight into the nature of synergistic sorptive interactions on spent shale, a second set of sorption-isotherm experiments was performed under the same conditions as the first experiment except that analytical-scale DOC fractionations (Leenheer and th Huffman, 1979) were performed on the non-sorbed solutes in whole retort wastewater after equilibration. Thus, relative sorption of the various fractions could be determined by comparison of DOC fractionations before and after sorption. Results of this experiment are shown in figure 5 (Leenheer, 1980).

This experiment confirmed the expected great sorptive capacity for the hydrophobic-neutral fraction predicted

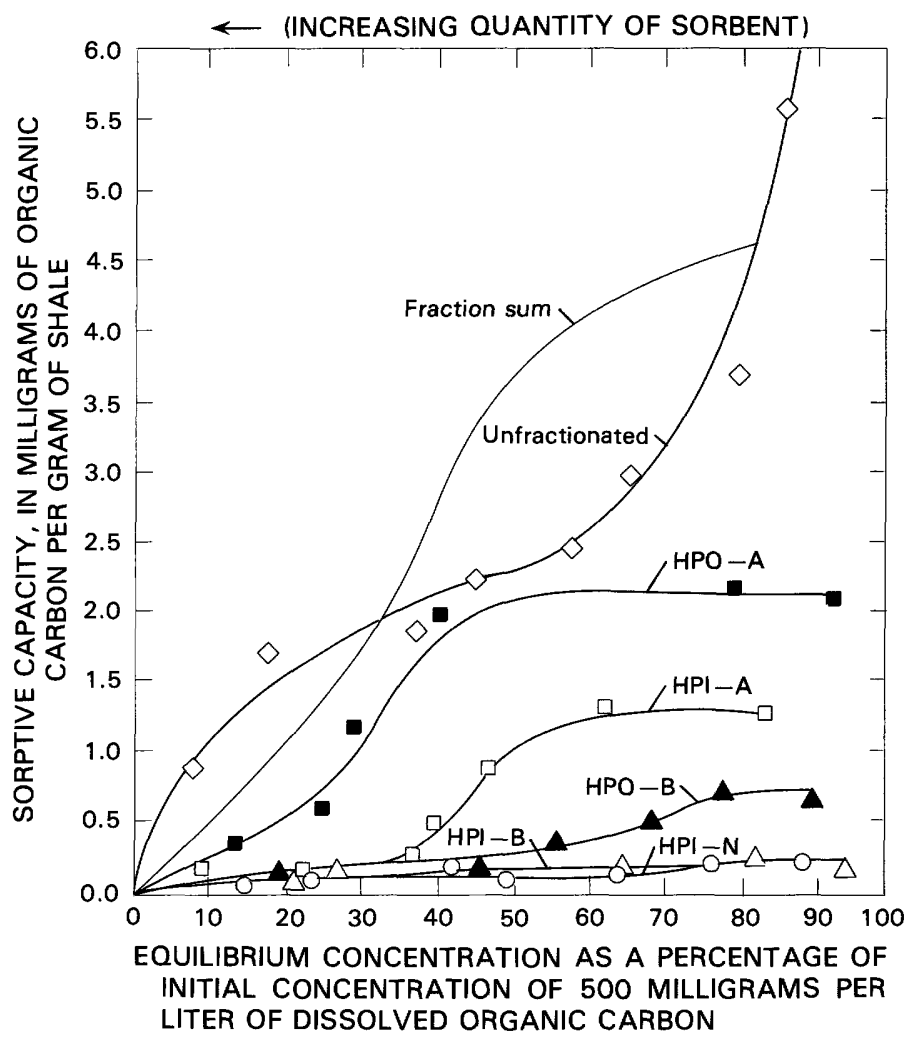

FIGURE 4.-Sorption isotherms $\left(25^{\circ} \mathrm{C}\right)$ of dissolved organic-carbon fractions in 150-ton retort wastewater on TOSCO-II processed shale (from Leenheer, 1980). Preparative-scale dissolved organiccarbon fractionation preceded sorption. (HPO-A is hydrophobic acids; HPI-A is hydrophilic acids; HPO-B is hydrophobic bases: HPI-B is hydrophilic bases; and HPI-N is hydrophilic neutrals.)

by the previous experiment and showed some synergistic relationships between the hydrophobic-neutral fraction and hydrophobic- and hydrophilic-acid fractions. It appears that sorption of the hydrophobic-neutral fraction deactivates the spent-shale sorbent for sorption of the acid fractions at about 70 percent of initial concentration (fig. 5). At less than 70 percent of initial concentration, the hydrophobic-neutral fraction is mostly removed from solution and the acid fractions have greater sorptive capacities, which is partly reflective of the sorption isotherms shown in figure 4 . At more than 70 percent of initial concentration the acid fractions also show increased sorption, which may be an absorption phenomenon in the hydrophobic-neutral films coating the shale particles in this range of the sorption isotherm. All the other fractions also show the absorptive interaction with the hydrophobic-neutral fraction at more than 70 percent of initial concentration. Adsorption of the acid fractions is minimal at about 70 percent of initial concentration, probably because of charge exclusion due to the negative charge that shale particles obtain from coabsorbed acids in the hydrophobic-neutral coating. 


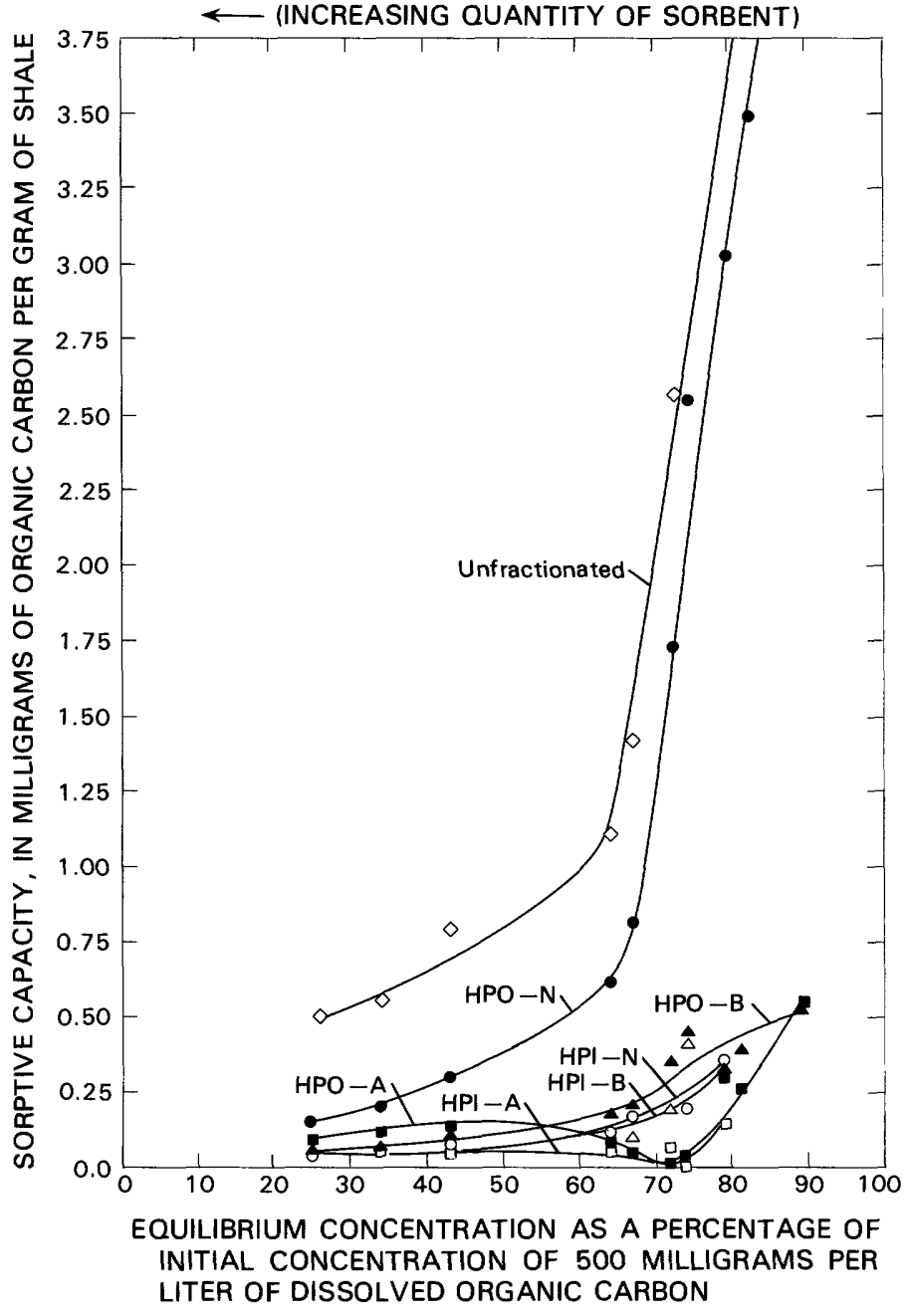

FIGURE 5. - Sorption isotherms $\left(25^{\circ} \mathrm{C}\right)$ of dissolved organiccarbon fractions in 150-ton retort wastewater on TOSCO-II processed shale (from Leenheer, 1980). Analytical-scale dissolved organic-carbon fractionation followed sorption. (HPO-A is hydrophobic acids; HPI-A is hydrophilic acids; HPO-B is hydrophobic bases; HPI-B is hydrophilic bases: and HPI-N is hydrophilic neutrals.)

The mechanism of organic-acid adsorption at less than 70 percent of initial concentration is less clear. It may be because retorting at $500^{\circ} \mathrm{C}$ produces alumina (Huggins and Green, 1973), which may adsorb organic anions during its rehydration with water. Retorting appears to activate oil shale with respect to sorption of organic-acid anions as a soil incorporating an oil-shale matrix from the Green River Formation showed no preferential sorption of organic-acid anions (Leenheer, 1980).

A conceptual model relating adsorption-isotherm data in figure 5 to retort-wastewater infiltration through a TOSCO-II spent-shale column is presented in figure 6 . Zone 2 is about five times the length of zone 1 based on sorptive-capacity data assuming equilibrium sorption.

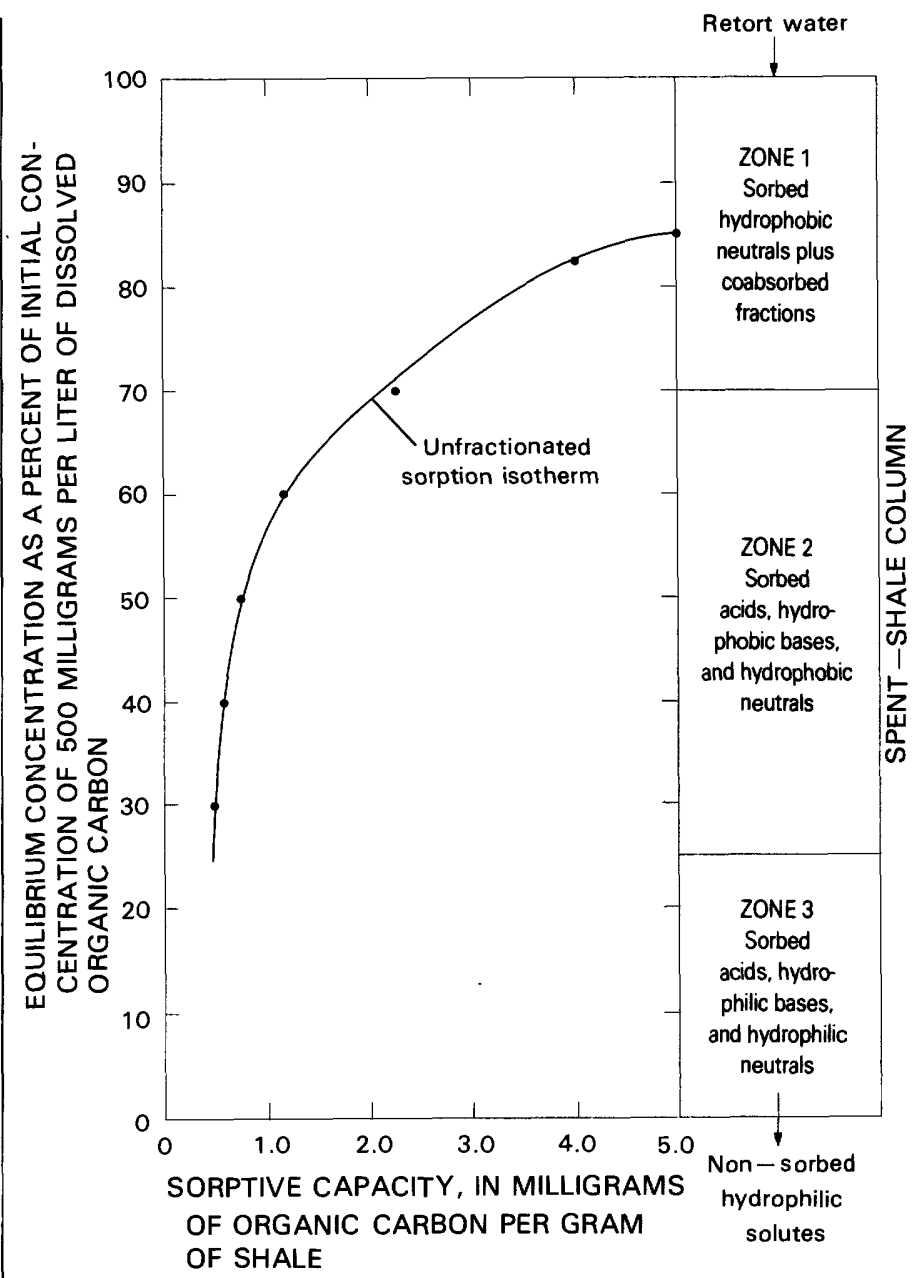

FIGURE 6. - Conceptual model of sorption of organic solutes in retort wastewater during infiltration through a TOSCO-II spentshale column.

No limits can be established for the relative length of zone 3 , because 100 percent sorption of DOC was not attained in the experiments. Some hydrophilic organic solutes may never be preferentially sorbed relative to water and will elute from the column at the point of water breakthrough. The lower limit of zone 2 , at which point 75 percent of the DOC was removed, corresponded to a $1: 1$ weight ratio of spent shale and retort wastewater. Because most proposals for codisposal involve a much greater ratio of TOSCO-II spent shale to retort wastewater, very large percent of adsorption of DOC on spent shale should be expected.

\section{COMPARISON OF SPENT SHALE AS A SOR BENT WITH GR ANULAR ACTIVATED CARBON}

The sorption-isotherm experiments presented previously indicated that the 4.5-percent elemental-carbon content of the TOSCO-II spent shale may be important in 
imparting a hydrophobic character to the sorbent surface, which facilitates sorption of hydrophobic solutes. To test this hypothesis, a sorption isotherm using Calgon Filtrasorb 400 granular activated carbon as the sorbent and 150-ton retort wastewater was determined under the same experimental conditions as described previously for the TOSCO-II spent shale. A direct comparison of the sorption isotherms for the TOSCO-II spent shale and the activated carbon (fig. 7) indicates relatively minimal sorptive capacities for the TOSCO-II spent shale. However, when the data are normalized for the elemental-carbon content of 4.5 percent, the spent-shale sorption isotherm compares with the activated carbon-sorption isotherm within a factor of 2 (fig. 8).

The TOSCO-II spent-shale sorption isotherm exceeds the activated carbon-sorption isotherm in figure 8 at both small and large equilibrium concentrations indicating that other factors besides elemental carbon control the sorption surface. At small equilibrium concentrations, spent shale shows a moderate affinity for acid anions, which may be related to basic oxide surfaces $(\mathrm{CaO}, \mathrm{MgO})$ created by retorting. At large equilibrium concentrations, coabsorption of all organic-solute fractions within a hydrophobic-neutral film is an important factor. Therefore, three factors appear to promote the sorption of organic solutes on TOSCO-II spent shale: (1) The elementalcarbon coating; (2) uptake of acid anions by a mineral surface activated by retorting; and (3) coabsorption of all organic-solute fractions within a sorbed hydrophobicneutral film. These various sorption mechanisms probably do not act independently on organic solutes, but rather reinforce each other (in most instances) resulting in increased sorption of solutes by multiple mechanisms.

\section{SUBSEQUENT STUDIES OF RETORT WASTEWATER- SPENT SHALE INTERACTIONS}

After the completion of this study of retort wastewaterspent shale interactions, two subsequent studies of this topic were made by Fox and others (1980) and Jackson and Jackson (1982). Fox and others (1980) conducted batch-and column-type studies using six separate spent shales and five different process retort wastewaters. Both studies found that the type of spent shale was a much more significant variable for sorption of organic solutes than was the type of retort wastewater. Organic-solute sorption increased as the elemental-carbon content of the spent shale increased, and sorption decreased as the retorting temperature increased, because increases in retorting temperature typically result in less carbonaceous coatings. Calcined and fused-clinker spent shales produced by high temperature retorting were poor adsorbents for organic constituents, but they removed most (97 to 99 percent) of the carbonate from retort wastewater.

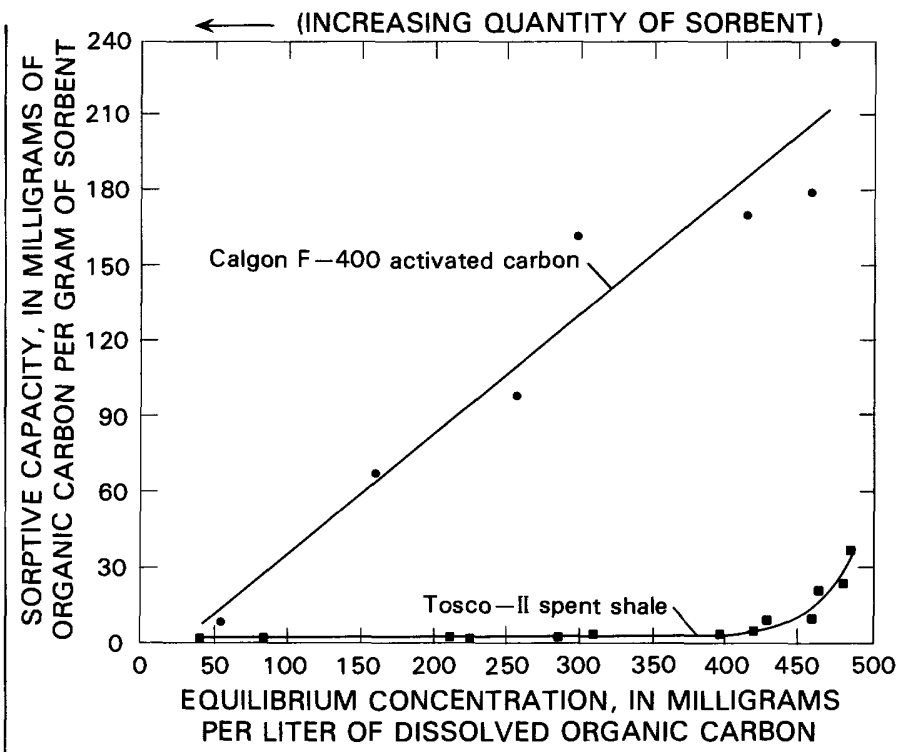

FIGURE 7.-Sorption of organic solutes in 150-ton retort wastewater on Calgon F-400 activated carbon and TOSCO-II spent shale (from Stuber and Leenheer, 1978a).

The most effective spent-shale sorbent for organic solutes was the TOSCO-II spent shale, which removed 48 to 73 percent of the DOC at a 1:1 weight mix ture of spent shale and retort wastewater.

The study by Jackson and Jackson (1982) used standard leach tests (American Society for Testing and Materials, 1982; U.S. Environmental Protection Agency, 1980) to determine if organic and inorganic constituents in four retort wastewaters codisposed with their four respective spent shales could be removed by leaching. They found efficient adsorption of total organic carbon from all tested retort wastewaters on spent shales, and the sorbed organic solutes were not leached significantly under the conditions of the test. These results are in accord with the results of this study and the study by Fox and others (1980), as all of the tested spent-shale sorbents were not calcined and had elemental-carbon coatings that made them efficient sorbents for organic constituents.

\section{RETORT WASTEWATER-SOIL INTERACTIONS}

The retort wastewater-soil interactions phase of this study was extensively researched because of the financial support by the Laramie Energy Technology Center, U.S. Department of Energy. Their support was to study the effect of a spill of retort wastewater on soils at their Rock Springs, Wyoming, experimental in-situ retorting site. A retort wastewater, designated Omega-9, produced at their site-9 retort, was collected in large quantities and preserved under refrigeration by Farrier and others (1977) and characterized by Fox and others (1978). 


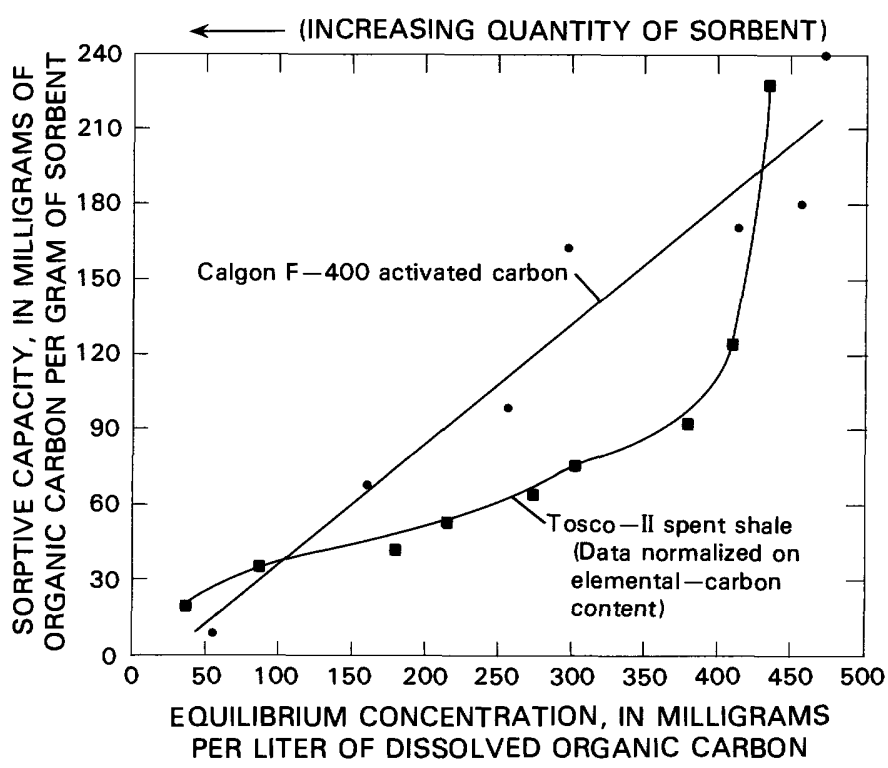

Figure 8. - Sorption isotherm $\left(25^{\circ}\right.$ Celsius $)$ data for TOSCO-II spent shale normalized on elemental-carbon content (4.5 percent by weight).
After characterizing the physical and chemical properties of the soils at the site by a first-order soil survey (Woodward-Clyde Consultants, 1978), the deepest soil at the site from the Haterton soil series was selected for intensive study. The deepest soil was selected to maximize interactions with retort wastewater passed through the soil. This soil was sampled approximately $193 \mathrm{~km}$ east of site 9 where the Omega-9 retort wastewater was produced. The soil was classified as a fine-loamy, mixed (calcareous) frigid, shallow family of Typic Torriorthents, whose surface (A) horizon is a light gray, alkaline loam, approximately $50 \mathrm{~mm}$ thick, with various subsoil (C) horizons consisting of alkaline clay loams. During sampling, the soil was divided into the following horizons: A (0-50 mm depth); $C_{1}\left(50-360 \mathrm{~mm}\right.$ depth); $\mathrm{C}_{2}$ (360-660 mm depth); and $\mathrm{C}_{3}$ (660-1,000 mm depth). Directly below the $\mathrm{C}_{3}$ horizon is weathered oil shale of the Green River Formation.

Results of the retort wastewater-soil interactions study have been extensively presented and interpreted in prior publications (Leenheer, 1980; Leenheer and others, 1981;

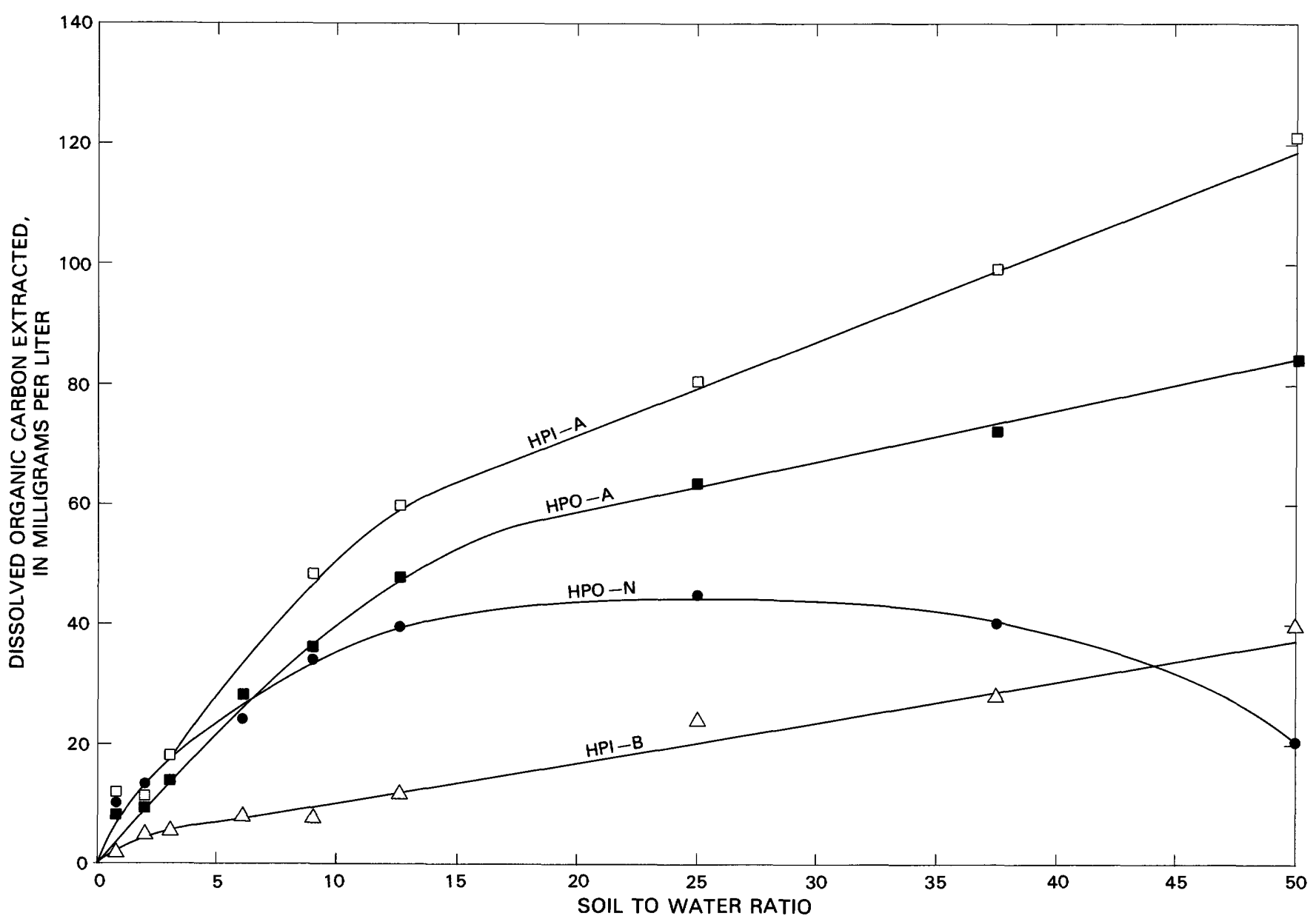

FIGURE 9. - Extraction isotherms $\left(25^{\circ} \mathrm{C}\right.$ ) of dissolved organic-carbon fractions from site-9 soil by Omego-9 retort wastewater (from Leenheer, 1980). (HPO-A is hydrophobic acids; HPI-A is hydrophilic acids; HPI-B is hydrophilic bases; and HPI-N is hydrophilic neutrals.) 
Leenheer and Stuber, 1981). Therefore, only a minimal description of the experimental procedures and data will be presented in this report, and the results and interpretations will be emphasized.

\section{BATCH-SORPTION EXPERIMENTS}

The first set of sorption experiments with soil used the same batch-equilibrium methods as was used previously with spent shale. However, more organic carbon was extracted from the soil by retort wastewater under certain conditions than was sorbed from retort wastewater by soil. To quantify and ascertain the nature of these organic constituents, a synthetic inorganic retort wastewater was prepared based on the analysis of Omega-9 retort wastewater by Fox and others (1978). Organiccarbon extraction isotherms were generated using the same methods for sorption isotherms presented previously (Stuber and Leenheer, 1978a), except that synthetic retort wastewater and the A horizon of the Haterton soil were used, and DOC fractionation was performed on the extracted organic solutes after equilibration. The extraction-isotherm data are shown in figure 9 (Leenheer, 1980).

The majority of extracted material was found to be organic acids that are derived from soil humic and fulvic acids. Insignificant quantities of hydrophobic-base and hydrophilic-neutral fractions were extracted; therefore, these data were not plotted in figure 9 . The hydrophobicneutral fraction does not parallel extraction trends of the other DOC fractions, but decreases after reaching a maximum near the 25-percent soil to water ratio. This decrease may be related to a salting-out effect caused by coextracted organic acids and bases.

The extraction isotherms in figure 9 were used to correct the batch-sorption isotherms for extracted organic matter, and the resulting retort wastewater-soil sorption isotherms are presented in figure 10 . The sorption isotherms in figure 10 when compared to the sorption isotherms in figure 5 indicate that soil is not as efficient a sorbent as TOSCO-II spent shale because sorptive capacities of the unfractionated isotherm for soil are only about two-thirds the sorptive capacity for spent shale. The sorptive capacities for the base and neutral fractions are similar for both soil and spent shale, but most of the reduced sorptive capacity for soil can be attributed to the lower sorptive capacities for the acid fraction. The cation-exchange capacity data for soil and spent shale (Cowling, 1979) indicate that soil is much more negatively charged than spent shale, thus minimizing sorption of acids through charge (ion) exclusion. The formation of enhanced negative charge through coabsorbed acids in the hydrophobic-neutral film is not apparent in soil as it was for spent shale as evidenced by the minima in sorptive capacities for the acid fractions at Ceq (carbon

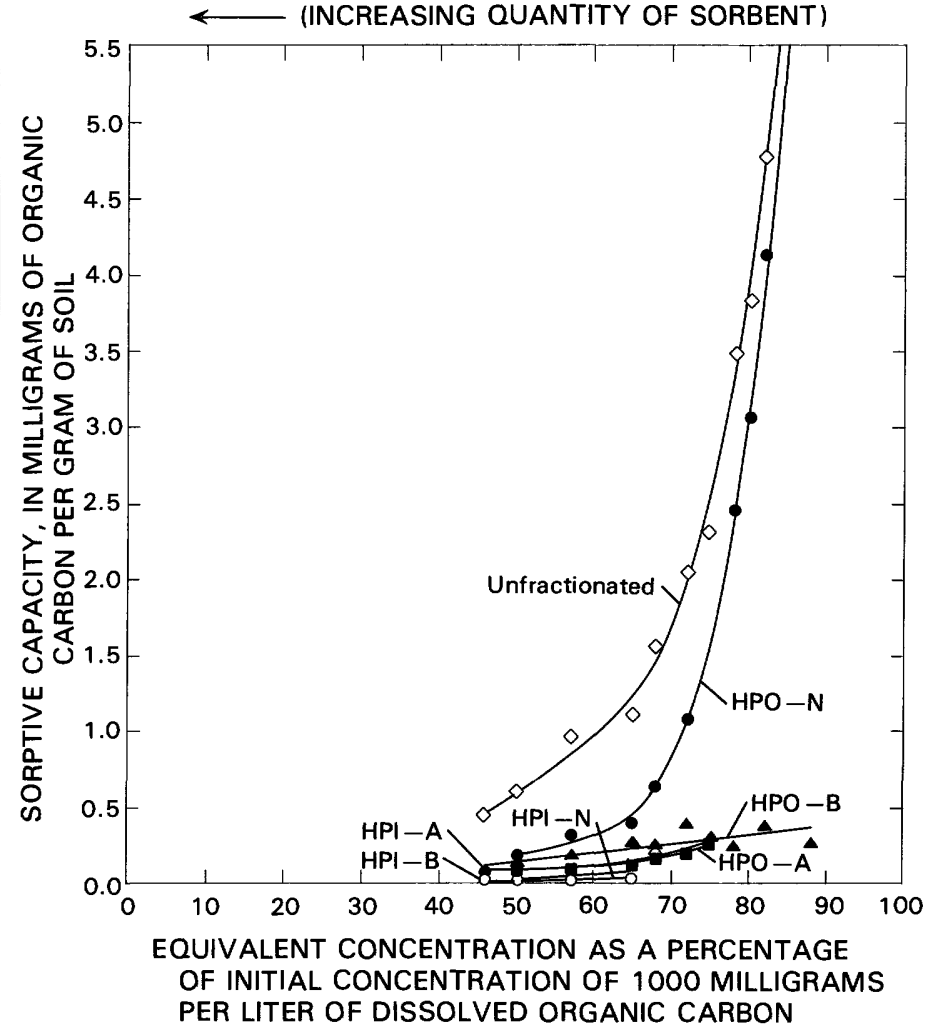

FIGURE 10. - Sorption isotherms (25 $5^{\circ}$ Celsius) of dissolved organiccarbon fractions in Omega-9 retort wastewater on site-9 soil (modified from Leenheer, 1980). Analytical-scale dissolved organic-carbon fractionation followed sorption. (HPO-A is hydrophobic acids; HPO-B is hydrophobic bases; HPO-N is hydrophobic neutrals; HPI-A is hydrophilic acids; HPI-B is hydrophilic bases; and HPI-N is hydrophilic neutrals.)

equivalent $)=70$ percent in figure 5 . The negative-charge density of soil is most likely already significant enough to prevent additional negative charges from forming through the sorption of organic acids. The soil data again show the importance of organic-acid sorption on spent shale.

\section{SOIL COLUMN-SORPTION EXPERIMENTS}

A number of soil-column experiments were done to obtain information about the various interactions of retortwastewater solutes with soil. Omega-9 retort wastewater was passed through a large soil column composed of reconstituted horizons from the Haterton soil. Three experiments were conducted to differentiate among soil constituents that are leachable with distilled water, constituents that are extracted from or adsorbed by soil using synthetic inorganic retort wastewater, and constituents that are extracted from or adsorbed by soil using Omega-9 retort wastewater. In the soil-column experiments that used synthetic and Omega-9 retort wastewaters, distilled water was passed through the column after the 


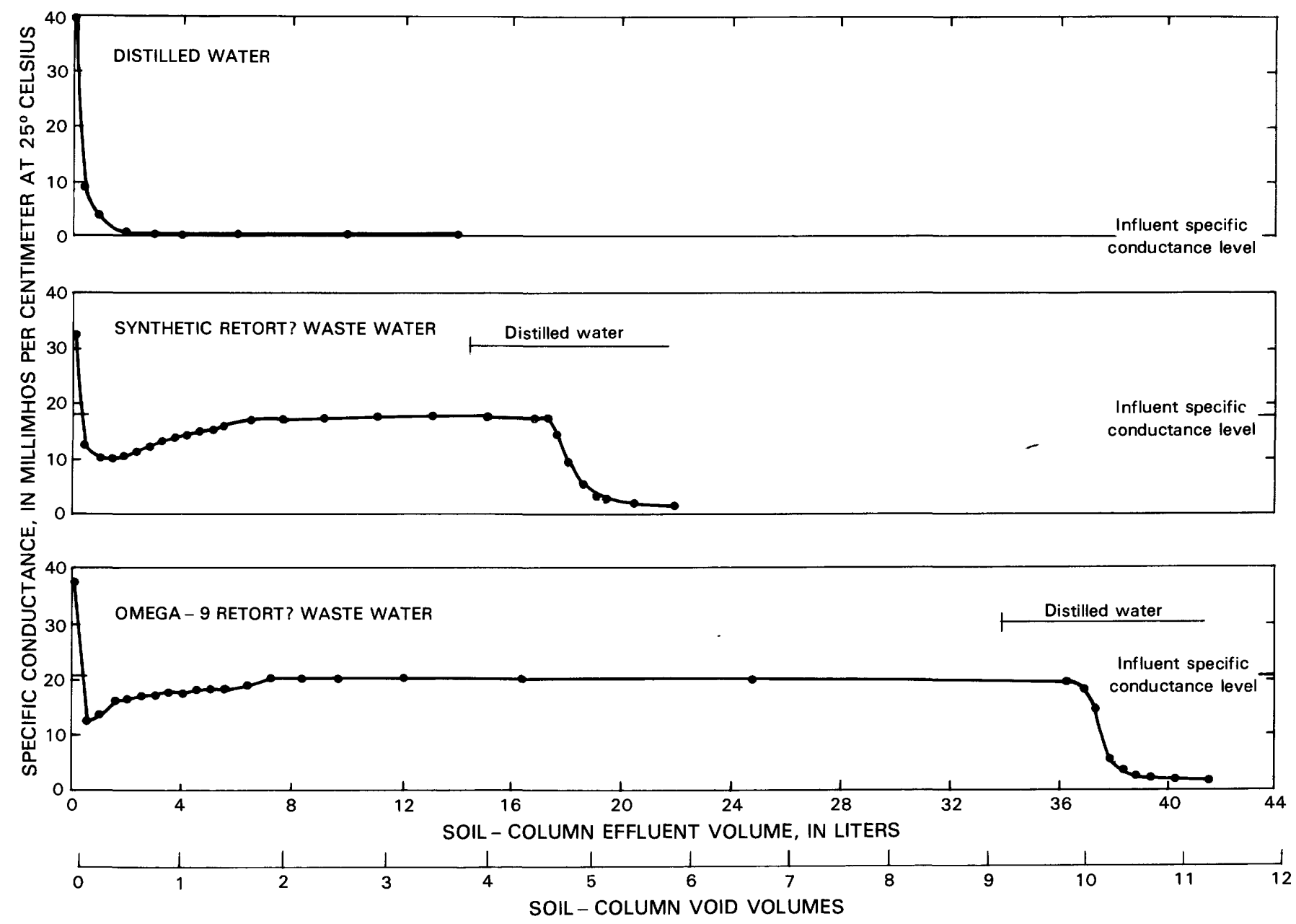

FIGURE 11.-Specific-conductance curves of soil-column effluents (modified from Leenheer and others, 1981).

retort wastewater to determine which sorbed constituents would be released in a situation analogous to precipitation leaching of soil after a retort-wastewater spill. Leenheer and others (1981) describe the physical and inorganic-constituent interactions; Leenheer and Stuber (1981) describe organic-constituent interactions.

\section{PHYSICAL AND INORGANIC-CONSTITUENT INTERACTIONS}

All the soil-column-effluent data were graphed in the same manner with influent concentrations marked on the ordinate and with identical concentration-volume and void-volume scales for all three soil-column experiments. About twice the volume of Omega-9 retort wastewater was passed through the soil column compared to the effluent volumes of the previous two experiments to obtain more complete information about the retention of organic solutes in retort wastewater. Specific conductance is plotted in figure $11, \mathrm{pH}$ in figure 12 , and color in figure 13.
Significant values for specific conductance in the first liter of eluate (fig. 11) for all three experiments indicate soluble salts leaching from the column. The decrease in specific conductance to values less than those of the influent from until about 0.5 to $7 \mathrm{~L}$ of effluent and passed through the columns during the retort-wastewater experiments indicates reactive processes, which are removing ionic solutes. Examination of the elution curves of major constituents (Leenheer and others, 1981) in the region where the decrease in specific conductance occurred revealed that as ammonium and bicarbonate were being sorbed by the soil column, magnesium, calcium, and potassium were being eluted. An ionic mass balance for major ions adsorbed and eluted from the soil columns in shown in table 6 . Precipitates analyzed to be calcium carbonate were observed eluting from the soil column during the decrease in the specific conductance, and the deficit in cations eluted (table 6) is evidence that most of the displaced calcium exchanged by ammonium ion remained in the column as precipitated calcium carbonate. Thus, the decrease in the specific conductance is due to 

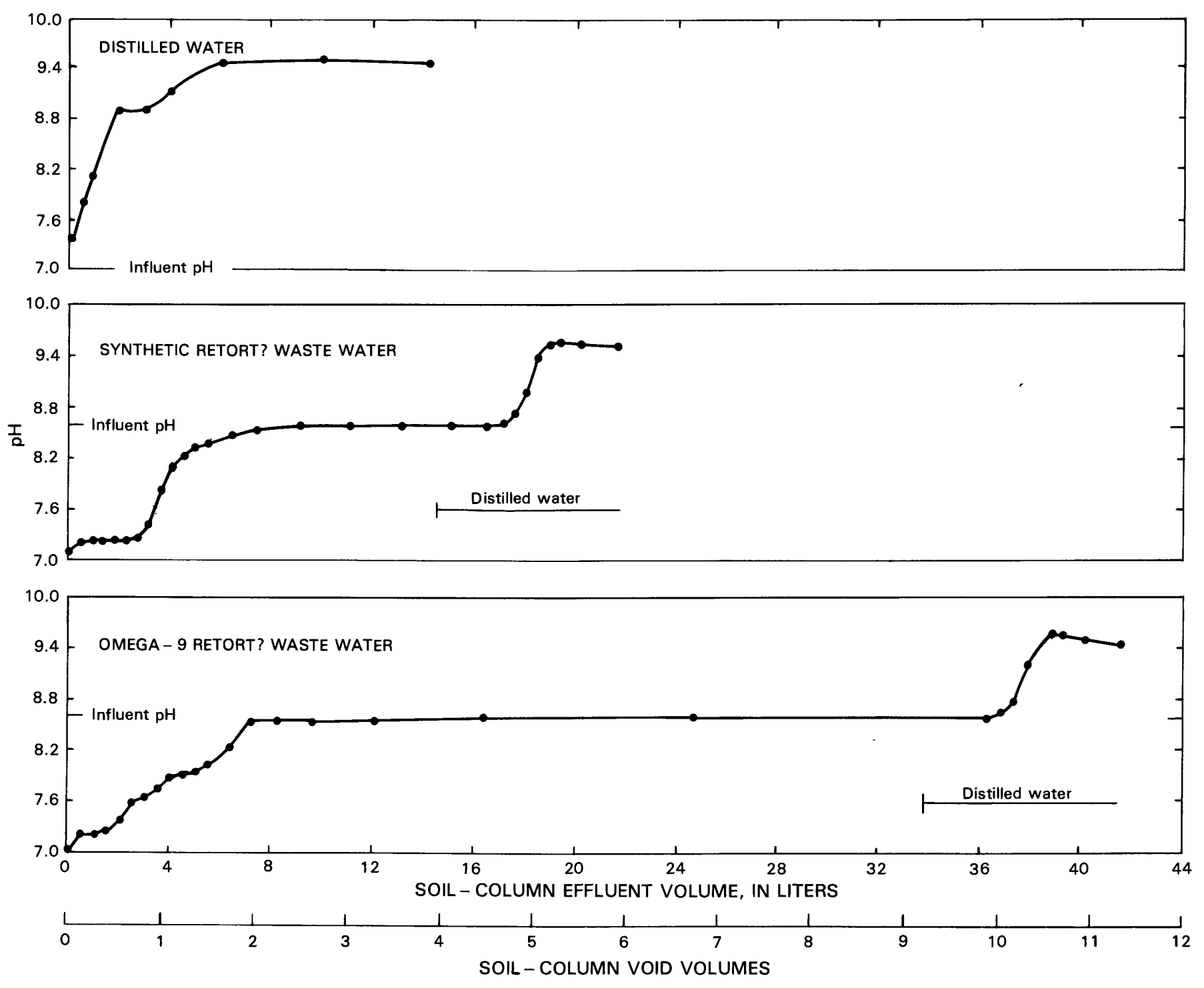

FIGURE 12. - pH curves of soil-column effluents (modified from Leenheer and others, 1981 ).

removal of ammonium ion by ion exchange and removal of bicarbonate by precipitation with calcium. Magnesium is the major ion eluted by this exchange process because of its abundance on soil-exchange sites and lack of controls on its solubility.

The $\mathrm{pH}$ data graphed in figure 12 show three plateaus for the retort-wastewater experiments. The $\mathrm{pH}$ of the first plateau of 7.2 results from sodium and magnesium bicarbonate buffering of the effluent, after removal of ammonium by cation exchange and carbonate by precipitation. The $\mathrm{pH}$ of the second plateau of 8.6 corresponds to the influent $\mathrm{pH}$, and the $\mathrm{pH}$ of the third plateau of nearly 9.5 results from a decrease of the common-ion effect during the distilled-water rinse on ammonium humates formed during retort-wastewater saturation of the soil.
The color curves in figure 13 give an indication of the points in the elution curves where soil organic matter is extracted by retort wastewater. A small color peak occurs where ion-exchange and precipitation processes discussed affect effluent chemistry; however, the major extraction of soil organic matter occurs during the distilled-water rinse. A conceptual model of major soil-retort wastewater interactions is presented by the two reactions in figure 14. When ammonium breaks through the soil column in the first reaction (fig. 14), a minor quantity of humic substances is solubilized as ammonium salts, which causes the first color peak of the elution curve; however, the relative large ammonium concentration of retort wastewater compresses the electrical double layer around humate macromolecules, which limits the dissolution of sparingly soluble ammonium humate salts through the common- 

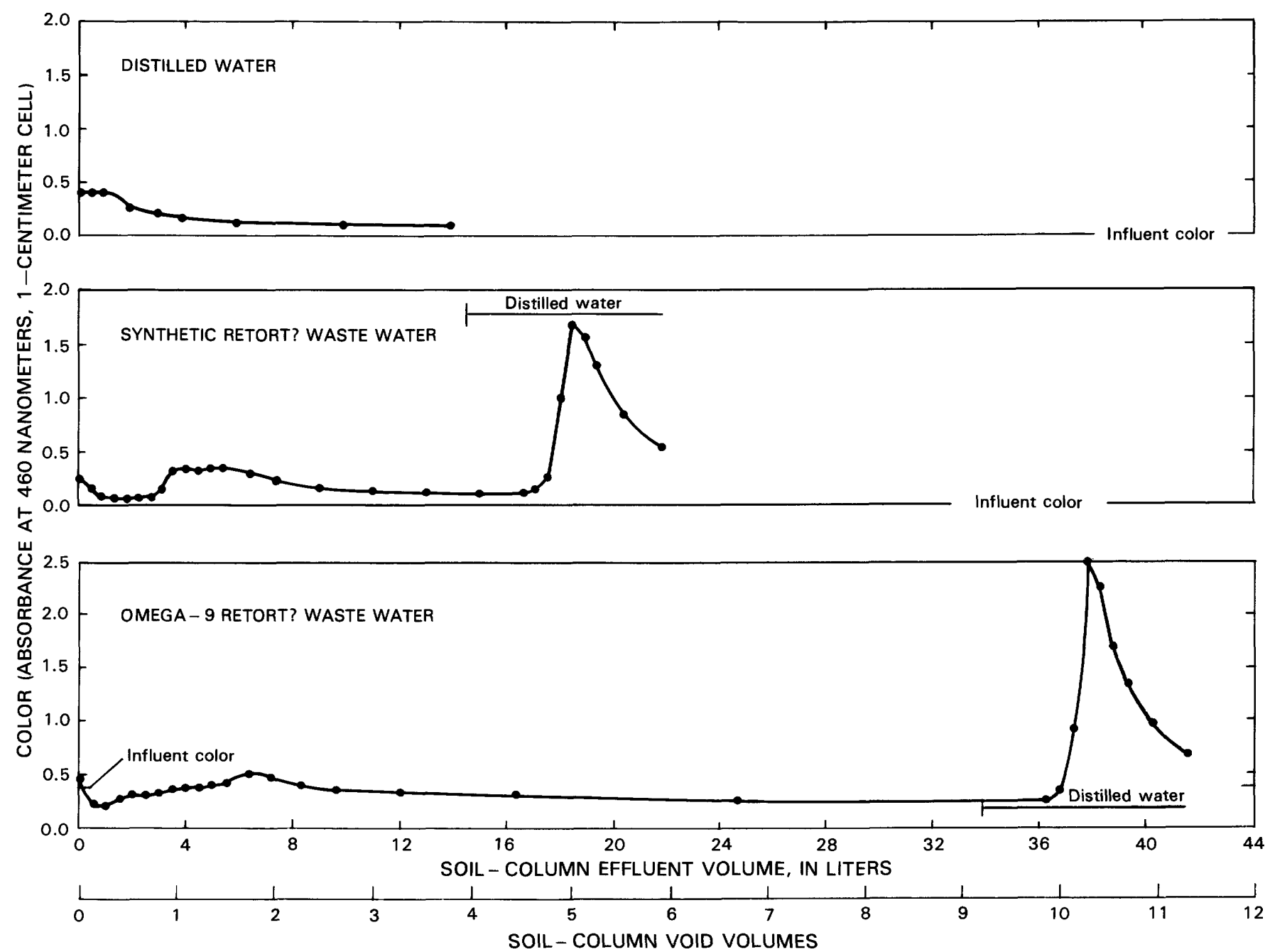

FIGURE 13. - Color curves of soil-column effluents (modified from Leenheer and others, 1981).

ion effect. When ammonium concentrations are decreased during the subsequent distilled-water rinse, a flush peak of humate anions occurs due to the decrease of the common-ion effect on solubility, as shown by the second reaction (fig. 14).

These chemical reactions also affect soil permeability and porosity. Flow rate of the soil-column effluent gave an estimate of the physical changes occurring within the soil column because the hydrostatic pressure on the top of the soil column was kept approximately constant throughout the experiments. Flow-rate curves are presented in figure 15. The flow-rate curve for the distilledwater leaching experiment showed nearly a linear decrease with volume, as the soil dispersed and compacted. However, flow-rate curves of the retort-wastewater experiments showed major variations that coincided with the effluent volumes of the various reactions discussed previously. Flow rate initially decreased from 0.5 to as much as 1 void volume. This decrease was most likely related to calcium carbonate precipitation and displacement of air within the columns. Flow rate then increased to a peak at approximately 2 void volumes. This peak probably was related to soil colloid shrinkage because of electrical double-layer compression due to the great ionic strength of retort wastewater. The subsequent flow-rate decrease similar to that of the distilled-water rinse probably represented gradual disaggregation of soil aggregates; a final small decrease in flow rate during the distilled-water rinse may have represented soil-colloid expansion with the decrease of the common-ion effect on the electrical double layer.

Most of the minor inorganic constituents in the retort wastewaters interacted analogously with soil similarly to the major elements just discussed with the exception of thiocyanate, chloride, and molybdenum. These three constituents are anions with few or no solubility controls. The elution curve for thiocyanate (fig. 16) demonstrates that thiocyanate may be an excellent tracer for retort- 
TABLE 6. - Ionic mass balance for ions adsorbed and eluted from soil columns

\begin{tabular}{lcc}
\hline Constituent & $\begin{array}{c}\text { Synthetic } \\
\text { retort-wastewater } \\
\text { experiment } \\
\text { (milliequivalents) }\end{array}$ & $\begin{array}{c}\text { Omega-9 } \\
\text { retort-wastewater } \\
\text { experiment } \\
\text { (milliequivalents) }\end{array}$ \\
\hline $\begin{array}{l}\text { Total nitrogen adsorbed } \\
\text { (estimate for amnonia). }\end{array}$ & 955 & 983 \\
$\begin{array}{l}\text { Bicarbonate adsorbed. } \\
\text { Calcium eluted. }\end{array}$ & 496 & 303 \\
Magnesium eluted. & 73 & 51 \\
Potassium eluted. & 351 & 947 \\
Total bicarbonate adsorbed & 62 & 795 \\
$\quad$ (includes calcium, \\
magnesium, and potassium \\
eluted).
\end{tabular}

wastewater migration in soils and sediment because of its lack of sorptive interactions, its uniqueness to retort wastewater, and its moderately large concentration in retort wastewater. Thiocyanate does not biodegrade in anaerobic ground-water systems and can be detected by colorimetric methods at concentrations as low as $10 \mu \mathrm{g} / \mathrm{L}$.

Inorganic solutes sorbed from retort wastewater by soil include the cations: barium, cadmium, cobalt, copper, iron, and zinc, and the anions: arsenic, boron, and fluoride. The cations were sorbed through ion-exchange and complexation processes, and the anions were retained through solubility controls causing precipitation such as calcium fluoride precipitation. When the distilled-water rinse followed retort-wastewater leaching, decrease of solubility controls and release of humic acids and non-ionic ammonia caused the desorption of arsenic, barium, boron, cobalt, copper, fluoride, iron, and zinc. A typical sorptiondesorption elution curve is shown for copper in figure 17.

Lithium, sodium, potassium, strontium, and manganese were extracted by retort wastewater from the soil by the exchange process discussed previously for ammonium, magnesium, and calcium. A typical ion-exchange elution curve for potassium is shown in figure 18. Most of the soluble salts were leached from the soil columns within the first liter ( 0.26 void volume) of leachate. The salts consisted mainly of sodium, calcium, and magnesium chlorides, sulfates, and nitrates. Most of the nitrate was found to reside in the $\mathrm{C}_{3}$ soil horizon. Boron, silica,

Soil + Retort waste water $\longrightarrow$ Ammonium $\left(\mathrm{NH}_{4}\right)$ - saturated soil + Soil effluent + Calcium carbonate $\left(\mathrm{CaCO}_{3}\right)$ precipitate
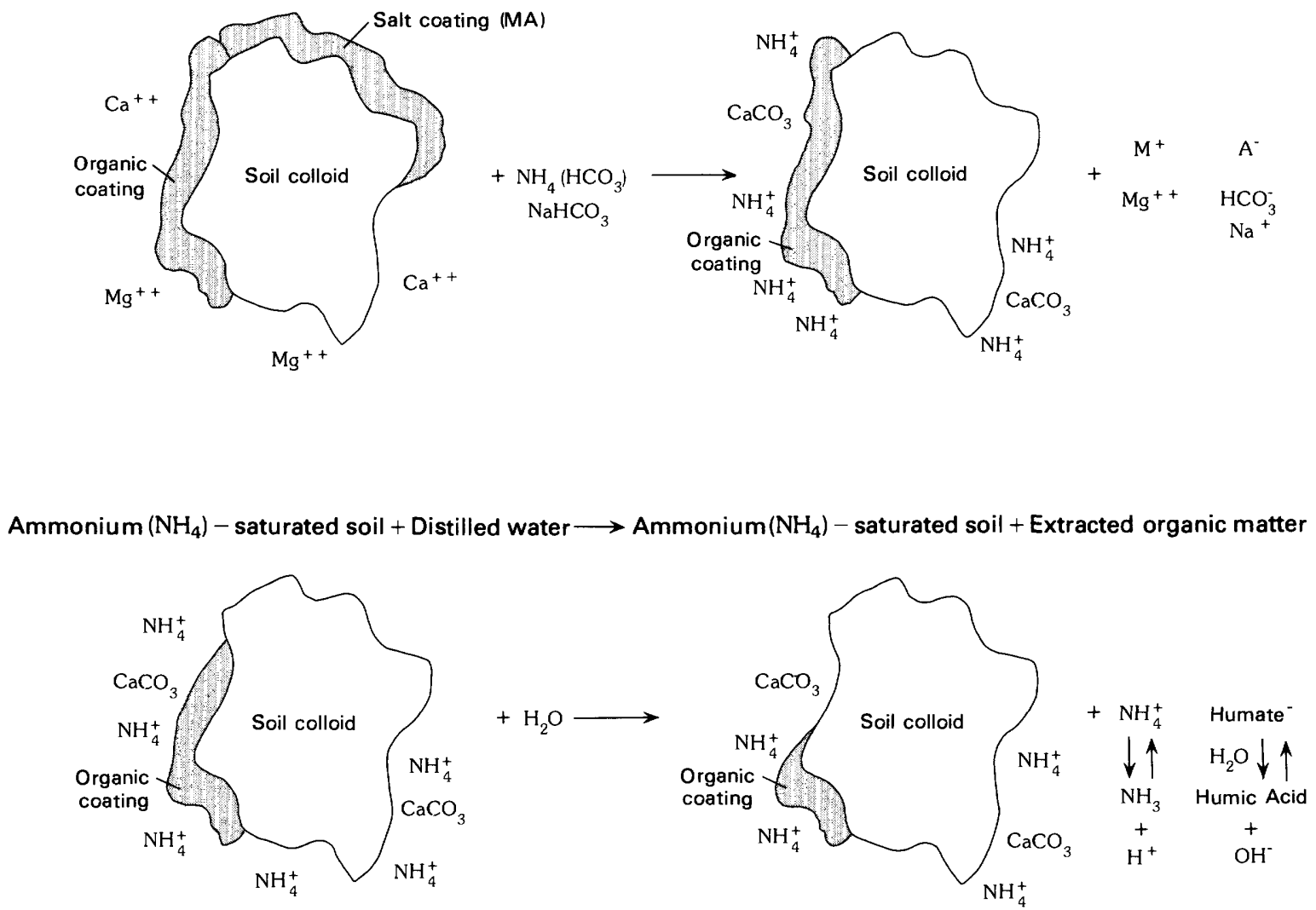

FIGURE 14.-Soil-retort wastewater reactions (modified from Leenheer and others, 1981). 


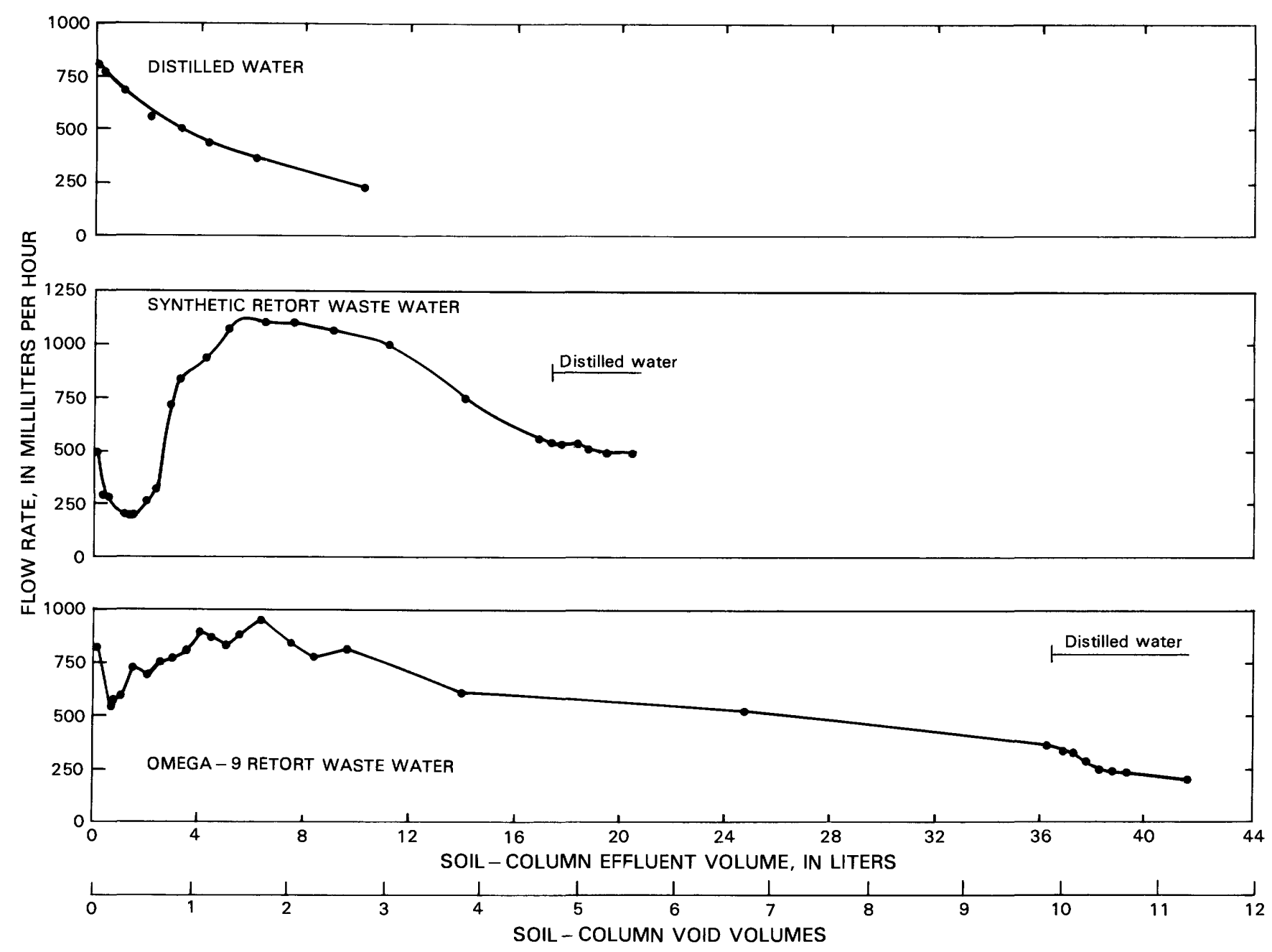

FIGURE 15. - Flow-rate curves of soil columns (modified from Leenheer and others, 1981).

and vanadium leached at a slower rate from the soil. Anomalously large concentrations of vanadium were found in the soil leachates. A typical salt leachate curve is shown by the curve for sulfate in figure 19 .

The reduced sulfur species, thiosulfate and tetrathionate, were found to be partly oxidized to sulfate during their passage through the soil column. In addition, 84 percent of the thiosulfate in Omega-9 retort wastewater oxidized to polythionates and sulfate during 3 years of refrigerated storage.

After the soil-column leaching experiments were completed, the soil was unpacked from the columns and dried for 2 weeks. Subsequent soil analyses for ammonia nitrogen (fig. 20) showed that much of the ammonium still was retained by the soil after drying. Data comparison of the total quantity of ammonium found by soil analysis of the columns leached with synthetic and Omega-9 retort wastewaters with the soil-exchange capacity of these columns found that about 65 percent of the exchange sites still were occupied by ammonium ion. This finding is somewhat surprising, because removal of a large percentage of ammonium was predicted during the distilledwater rinse that followed retort-wastewater leaching, by biological nitrification of ammonium to nitrate, and by volatilization from the alkaline soil during the 2-week drying period. At $\mathrm{pH}$ 9.5, which occurred during the distilled-water rinse, 76 percent of the ammonium plus ammonia species are present as free ammonia, which should leach or be volatilized from the soil. Significant losses of ammonium appeared to have occurred only in the shallow A horizon of the soil profile (fig. 20). Loss of ammonium in the A horizon may due to both leaching of ammonium humates and biological nitrification.

Soil minerology of the Haterton soil was determined to provide insight into the mechanism of anomalous ammonium ion retention. Little variation was found in minerology among the various horizons. An average minerological soil composition and the contribution of each mineral to the cation-exchange capacity of the soil is given in table 7 . 


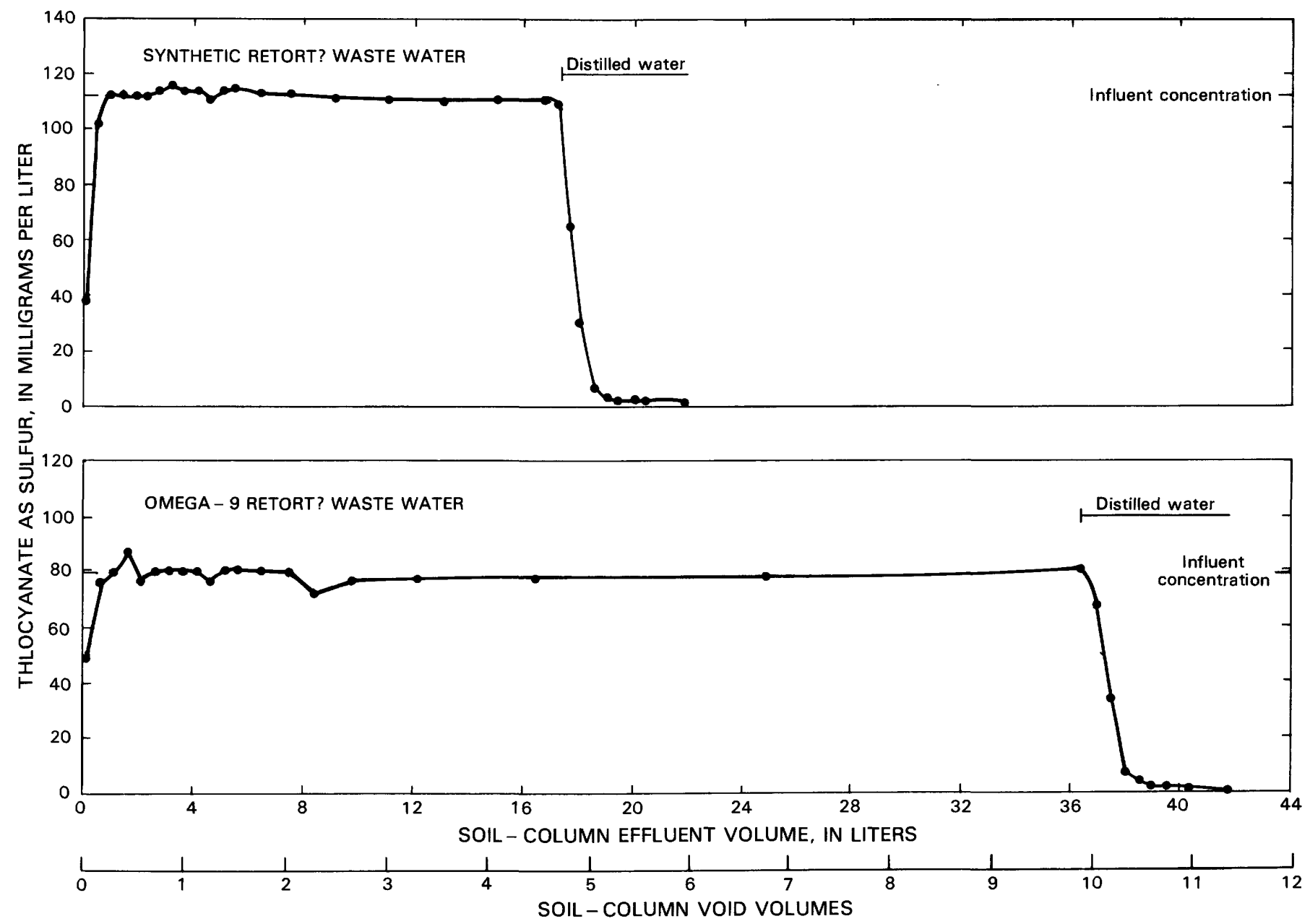

FIGURE 16. - Thiocyanate curves for soil-column effluents (modified from Leenheer and others, 1981).

One-half of the cation-exchange capacity in the Haterton soil was due to analcime, which is a zeolite; this is a significant finding, because analcime has small lattice pores, which permit moderately rapid cation exchange of sodium and potassium. Ammonium exchange is permitted, but the kinetics are slow. After drying, a slightly decrease in pore size fixes ammonium within the crystal lattice of analcime (El-Nahel and Wittig, 1973). This explains why ammonium was not lost by volatilization from soil during drying, and the slow kinetics of ammonium exchange may explain why it was not removed by the distilledwater rinse after retort-water leaching. Analcime occurs in most soils and sediments derived from the Green River Formation, thus ammonium sorption may be a major interaction between retort wastewater and soil.

Saponite and sepiolite clays account for most of the remaining exchange capacity. Both of these clays are magnesium enriched; this helps explain why magnesium was the most abundant cation exchanged for ammonium shown in the data in table 6 . The total cation-exchange capacity of $31 \mathrm{meq} / 100 \mathrm{~g}$ based on estimates of data shown in table 7 is somewhat similar to the exchangecapacity determination $(20 \mathrm{meq} / 100 \mathrm{~g}$ ) of WoodwardClyde Consultants (1978), because it is not an unreasonable estimate that some of the soil-exchange sites may be chemically and physically blocked resulting in a smaller experimentally determined value.

\section{ORGANIC-CONSTITUENT INTERACTIONS}

Dissolved organic-carbon curves for the soil-column effluents are shown in figure 21. The DOC in each of these three curves was subdivided by the DOC-fractionation procedure. Results for the distilled-water and synthetic retort-wastewater effluents, which extracted soil organic matter, were similar to the results of the batch-sorption procedure shown in figure 9 . To determine the sorption on soil of organic solutes from Omega-9 retort wastewater, DOC-fractionation data from synthetic retort-wastewater column effluent was subtracted from 

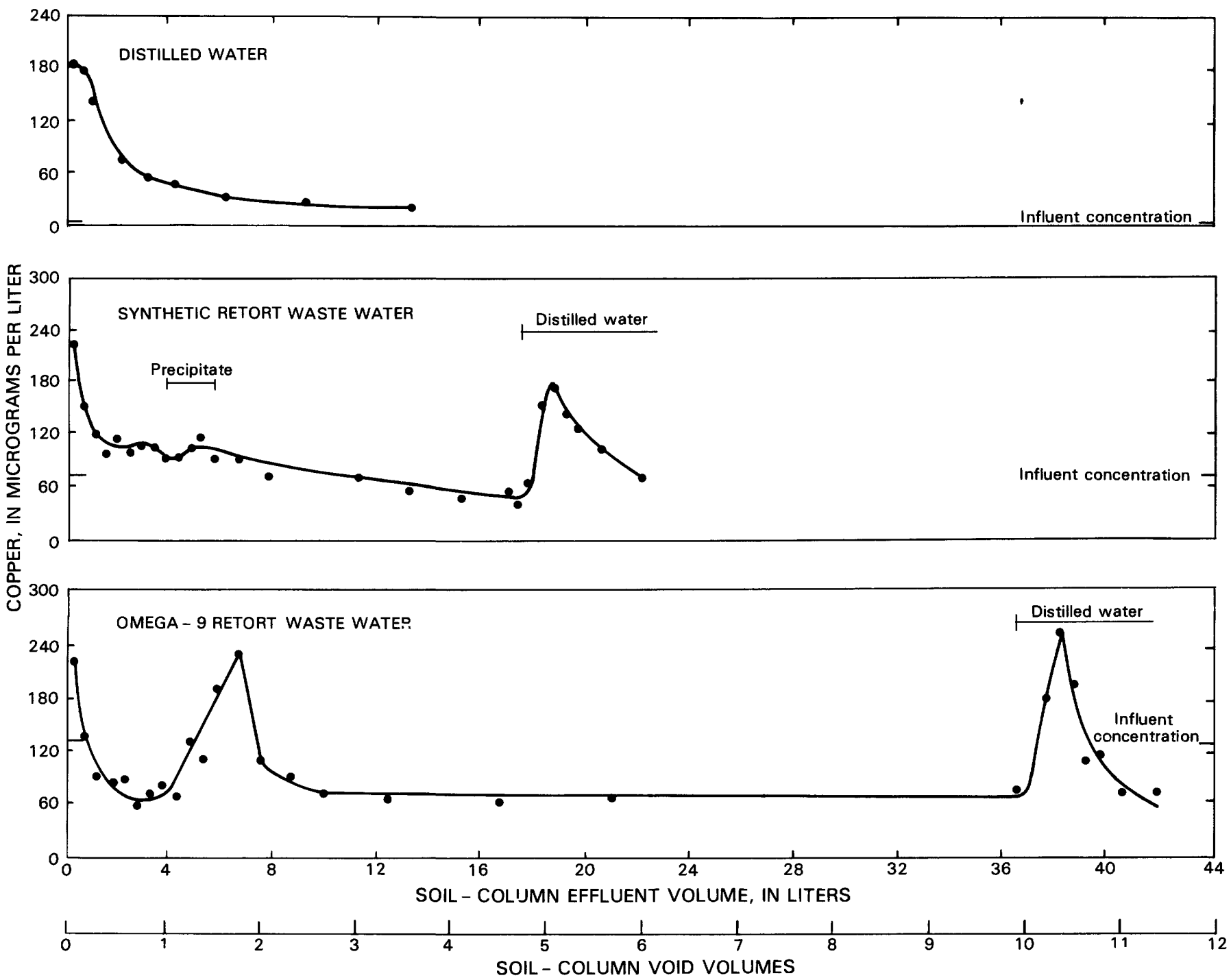

FIGURE 17.-Copper curves for soil-column effluents (modified from Leenheer and others, 1981).

DOC-fractionation data of Omega-9 retort-wastewater effluent. The results of this data subtraction was plotted on the ordinate as the percent of influent concentration (fig. 22).

For the effluent-volume range from 10 to $36 \mathrm{~L}$ ( 2.6 to 9.4 void volumes), DOC fractions increased in affinity for the soil in the following order: hydrophilic neutrals $\cong$ hydrophilic acids < hydrophobic acids < hydrophilic bases $<$ hydrophobic neutrals $\cong$ hydrophobic bases. The previous batch-sorption isotherm study using the same retort wastewater and soil found that the hydrophobicneutral fraction had a much greater affinity than the other five fractions (fig. 10). However, the greater affinity for the hydrophobic-neutral fraction (fig. 10) only occurred at soil to water ratios corresponding to the 11 to 140 void-volume range, which was greater than the effluentvolume range of the present study. Examination of the data in figure 22 shows that the hydrophobic-neutral fraction becomes the fraction of greatest affinity for soil after $26 \mathrm{~L}$ (6.8 void volumes); the data in figure 10 indicate that the hydrophobic-neutral breakthrough curve continues to diverge from the other five fractions at larger effluent volumes.

In figure 22 , the flush peaks, which occur with the distilled-water rinse, elute later, become broader, and tail more as the affinities of the DOC fractions for soil increase. The flush peaks for the acid fractions can be ascribed to the decrease of the common-ion effect on solubility of ammonium salts of the acids, as ammonium concentration is decreased during the distilled-water rinse. However, flush peaks that also occur in the hydrophobic-base, hydrophilic-base, and hydrophobic-neutral fractions indicate some type of association between these fractions and organic acids of either soil or retort-wastewater origin, 


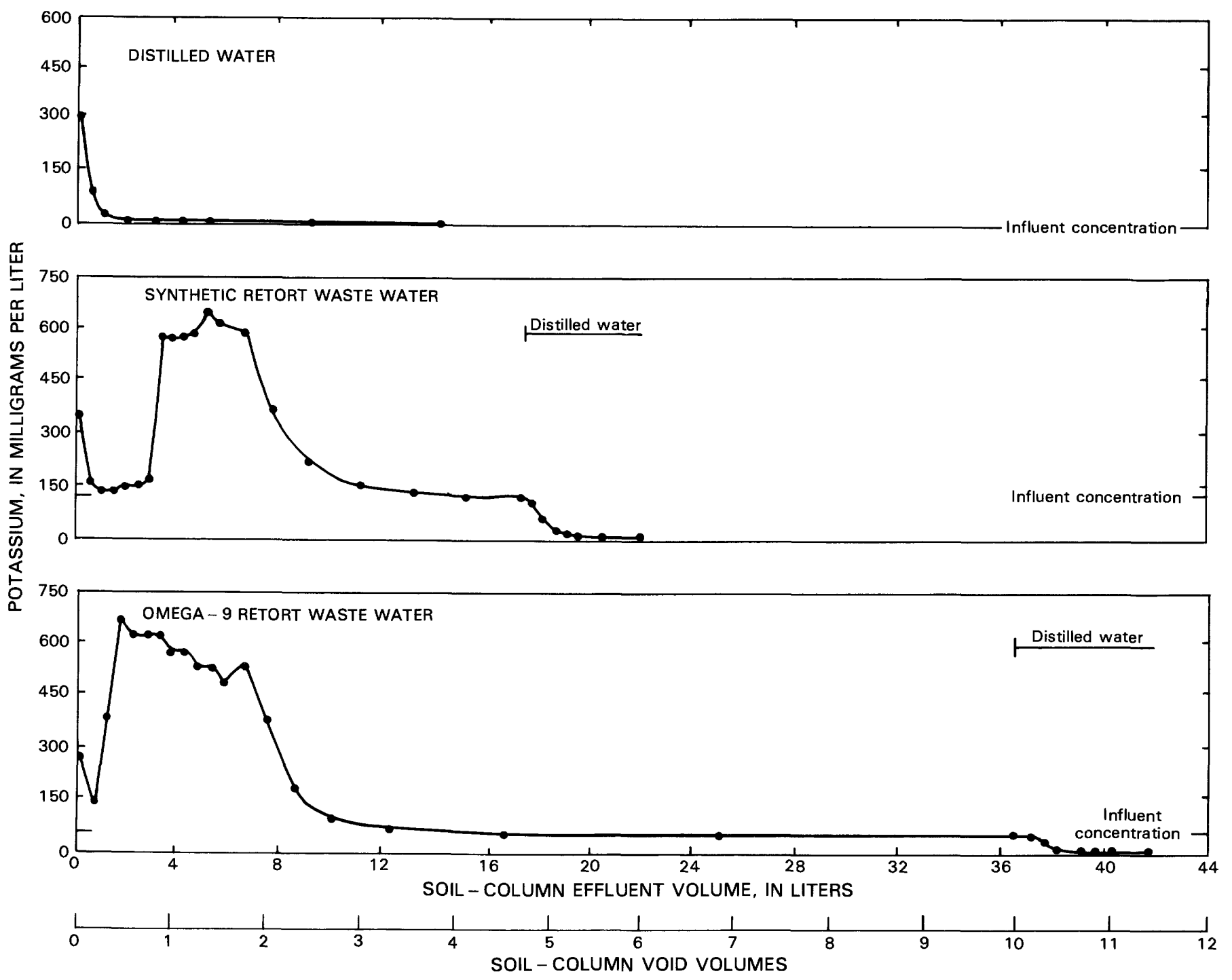

FIGURE 18. - Potassium curves for soil-column effluents (modified from Leenheer and others, 1981).

which are released during the distilled-water rinse. The hydrophilic-neutral fraction, which is least likely to associate with any sorbent or other solutes, does not show a flush peak.

The observed order of affinity of the DOC fractions for soil follows expectations based on soil properties as a sorbent. The hydrophilic-neutral fraction should have the least affinity for soil, because it did not sorb on the synthetic resins used in the DOC fractionation. This fraction does not have acid or base properties that can cause sorption by anion or cation exchange, and its hydrophilic properties limit physical sorption. Soil usually has a relatively large cation-exchange capacity compared to its anion-exchange capacity, which means that it is a negatively charged sorbent at most soil $\mathrm{pH}$ levels. Anions and organic acids should have less affinity for soil because of ionic exclusion between negatively charged solutes and negatively charged sorbents. The hydrophilicacid fraction has little affinity for soil. The hydrophobicacid fraction has greater affinity because of physicaladsorption interactions that can occur between the nonpolar hydrocarbon parts of hydrophobic-acid solutes and the nonpolar sorption sites on the soil column. The hydrophobic-neutral fraction has the greatest affinity for soil because it is the most water-insoluble, nonpolar fraction that is sorbed by the physical-sorption process.

The DOC-fractionation data shown in figure 22 offer qualitative mechanistic insights into the migration of various organic-compound groups through the soil column, but quantitative mechanistic interpretations of these data are complicated by the large number of compounds with different sorptive-capacity factors within each DOC fraction. The hydrophobic-base fraction was selected for the quantitative mechanistic study because of the ease 


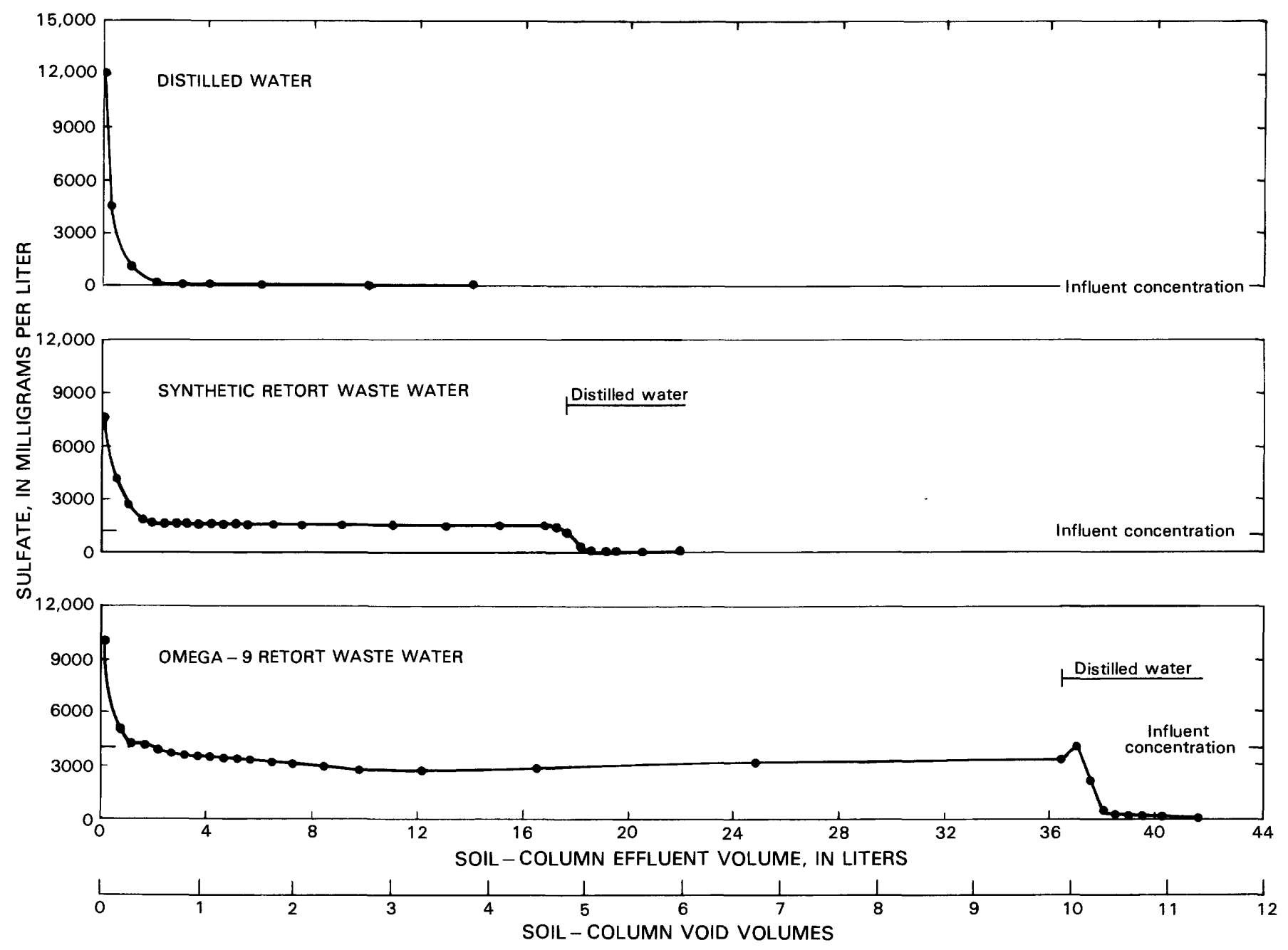

FIGURE 19. - Sulfate curves for soil-column effluents (modified from Leenheer and others, 1981).

of specific compound analysis by liquid chromatography and the importance of aromatic amines in this fraction as environmental contaminants.

Breakthrough curves for pyridine, 2-methylpyridine, 3- and 4-methylpyridine, a dimethylpyridine, and three quinoline compounds from the soil column are shown in figure 23. An important finding is that the relative order of the rates of migration through the soil column is exactly the same as the order of migration through the octadecylsilica, high-performance liquid-chromatography column used in the analysis of the aromatic amines.

To determine whether order of migration of aromatic amines through the soil column is quantitatively similar to the reversed-phase, high-performance, liquid-chromatography column, column capacity factors $\left(k^{\prime}\right)$ for both the soil and the analytical-chromatography column were computed, and their ratios for each aromatic amine were compared in table 8 . The capacity-factor ratio rapidly decreases between 2-methylpyridine and dimethylpyridine, which corresponds to an elution-volume range where the retort-wastewater mobile-phase chemistry changed because of salt (fig. 11) and DOC leaching of the column (fig. 21), ammonium sorption (table 6), and calcium carbonate precipitation (fig. 14). A physical consequence of the ion-exchange and precipitation reaction front was the displacement of air that would increase the wetted surface area of the column. Therefore, the likely cause of the sudden increase in soil-column capacity factors probably is related to the increase in wetted surface area and the change in retort-wastewater mobile-phase chemistry. These reaction-front changes affecting solute-column capacity factors also are probably instrumental in causing the unusual variations in DOC-fractionation data (fig. 22) for the 0.25 to 2.5 void-volume range. The column capacityfactor ratio (table 8) nearly is constant for dimethylpyridine, quinoline, and methylquinoline, which indicates that the hydrophobic effects that control the rate of migration through the analytical-chromatography column also are the primary sorptive mechanism in the soil column after the passage of the reaction front. 

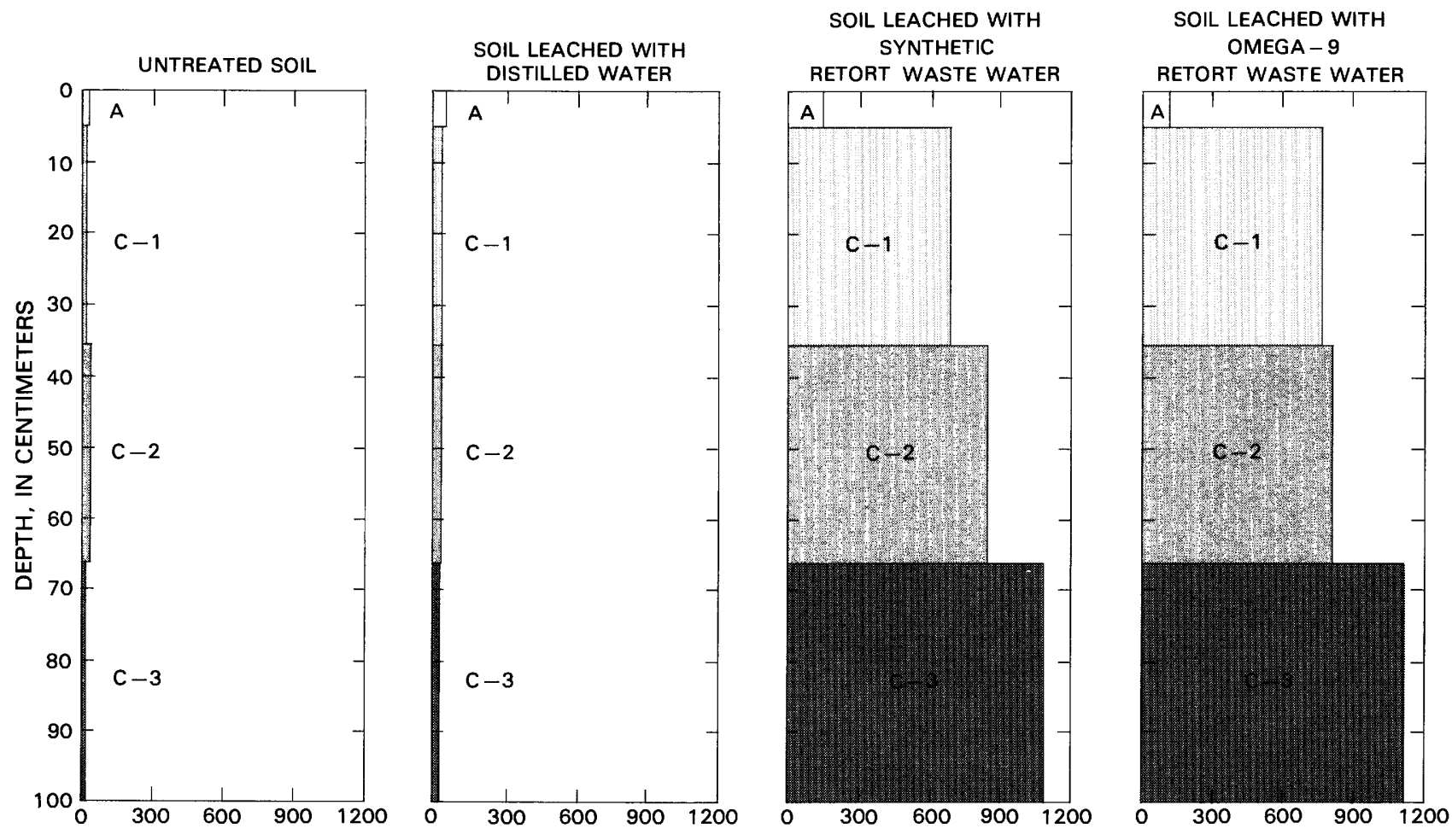

AMMONIA NITROGEN, IN MILLIGRAMS PER KILOGRAM

FIGURE 20.-Soil analyses for ammonia nitrogen (modified from Leenheer and others, 1981).

The aromatic amines all show significant flush peaks when distilled water is applied to the column (fig. 23). The size of this peak apparently is affected both by the quantity of the amine sorbed by the soil column and by its desorption rate in distilled water. Note that the de-

TABLE 7.-Cation-exchange capacity contributions of Haterton soil constituents

[NS, not significant]

\begin{tabular}{|c|c|c|c|c|}
\hline Constituent & $\begin{array}{c}\text { Exchange } \\
\text { capacity } \\
\text { (milliequivalents } \\
\text { per } 100 \text { grams) }\end{array}$ & $\begin{array}{c}\text { Percentage } \\
\text { of sorl } \\
\text { composition }\end{array}$ & $\begin{array}{c}\text { Sor1-exchange } \\
\text { capacity } \\
\text { (mılliequivalents } \\
\text { per } 100 \text { grams) }\end{array}$ & $\begin{array}{r}\text { Exchange } \\
\text { capacity } \\
\text { (percent) }\end{array}$ \\
\hline
\end{tabular}

\begin{tabular}{lrrrr}
\hline Calcite & NS & 18 & NS & NS \\
Dolomite & NS & 11 & NS & NS \\
Quartz & NS & 20 & NS & NS \\
Plagioclase & NS & 7 & NS & NS \\
$\quad$ feldspar & & & & \\
Potash feldspar & NS & 4 & NS & NS \\
Analcime & 400 & 4 & 16 & 51 \\
I111te mica & 12 & 9 & 1 & 3 \\
Saponite & 76 & 12 & 9 & 29 \\
Sepiolite & 32 & 11 & 3 & 9 \\
Kaolinite & 6 & 1 & NS & NS \\
Amphibole & NS & 2 & NS & NS \\
Organic matter & 200 & 1 & 2 & 6 \\
& & 100 & -31 & \\
\hline
\end{tabular}

creasing slope of the flush peaks is steepest for the most soluble amines (pyridine, methylpyridine) and flattest for the most hydrophobic amines (quinolines). As discussed in the previous section, these flush peaks are a result of stripping the natural organic-matter coating from the soil by distilled water.

\section{CONCLUSIONS ABOUT RETORT WASTEWATER-SORBENT INTERACTIONS}

The TOSCO-II spent shale of this study is an effective sorbent for many organic constituents in retort wastewater and would be worthy of future research for a candidate sorbent matrix in which retort wastewaters could be codisposed. Sorption of organic acids is an unusual property of TOSCO-II spent shale, which makes it more effective as a sorbent compared to other spent shales and soils. Subsequent studies by other investigators have confirmed these findings about the TOSCO-II spent shale and also have indicated that calcined spent shales produced by higher temperature retorting processes are very poor sorbents for organic solutes in retort wastewaters. In an in-situ retort where a variety of spent-shale types are produced, ground-water flow paths during backflooding or retort wastewater reinjection should be an important 


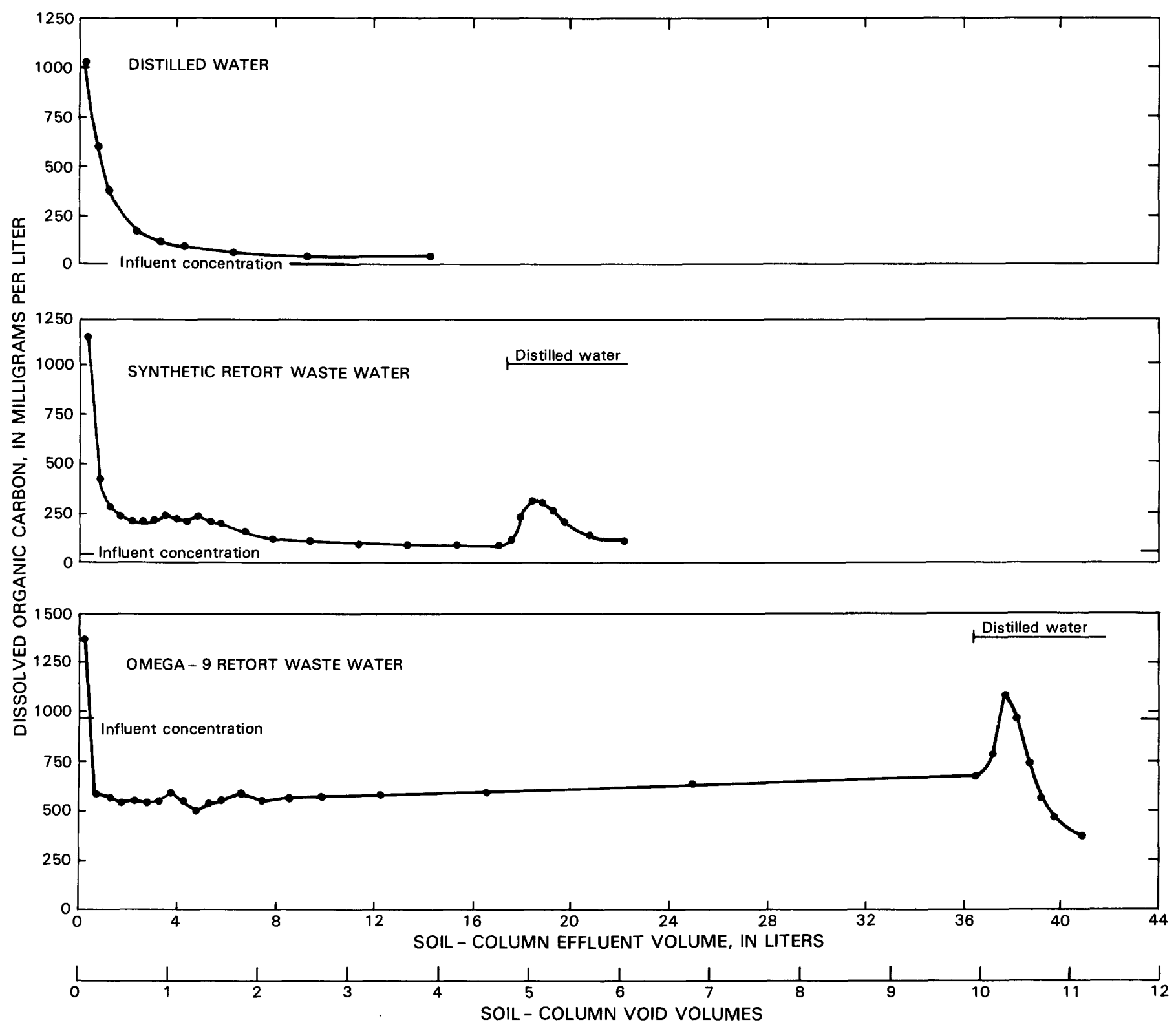

FIGURE 21.-Dissolved organic-carbon for soil-column effluents (modified from Leenheer and others, 1981).

factor in determining which types of spent shale are contacted and are the potential sorbents for various organic and inorganic constituents in retort wastewaters.

Soils developed where oil shale in the Green River Formation occurs have significantly different properties as a sorbent compared to spent shale. The Haterton soil of this study had good sorbent properties for ammonium because of the presence of analcime, which occurs in most soils and sediments of this region. Soils developed on the Uinta Formation, which overlies the Green River Formation, also typically contain significant quantities of analcime. The capacity for ammonium adsorption and fixation is a desirable property because ammonia generally is thought to be the source of most of the toxicity of retort wastewater. However, ammonium saturation of soil also resulted in extraction of large quantities of soil organic matter and concommitant release of previously sorbed organic and inorganic constituents when leaching by distilled water (or rainwater) followed retortwastewater application. This organic-matter extraction phenomenon should only occur after a relatively large retort-wastewater application ( 1 to 3 void volumes), which saturates the soil with ammonium. Smaller volume retortwastewater applications should result in partial to complete retention of most retort-wastewater organic solutes in the soil profile where they can be degraded by additional chemical and biological processes after retortwastewater evaporation. 


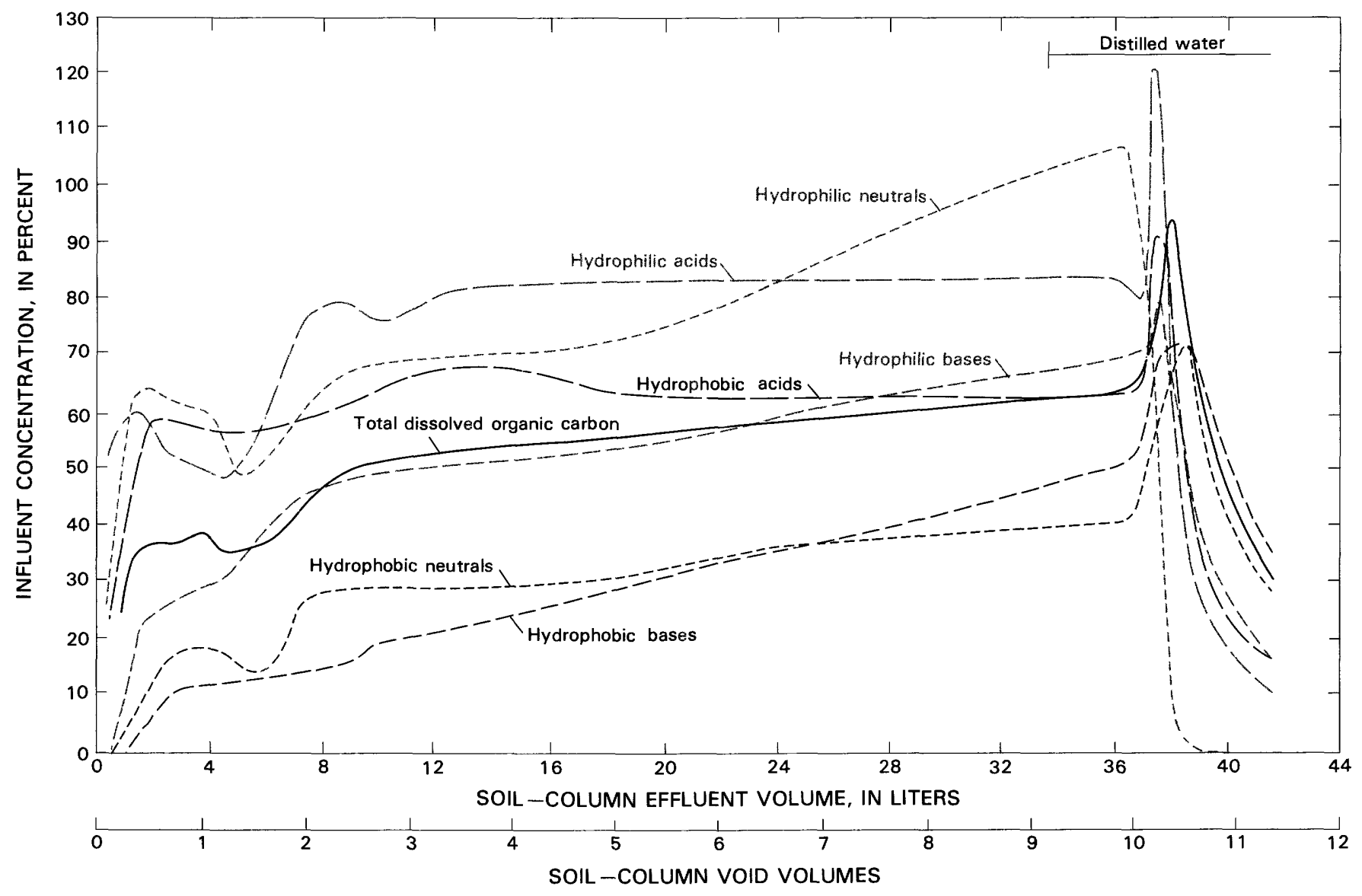

FIGURE 22. - Percentage breakthrough curves for dissolved organic-carbon fractionation of Omega-9 retort-wastewater leachate (modified from Leenheer and others, 1981).

\section{MICROBIOLOGICAL DEGRADATION OF ORGANIC SOLUTES IN RETOR T WASTEWATER}

The question of the biodegradability of retort-wastewater constituents is important because of the environmental effects of retort-wastewater constituents after discharge and the treatability of retort wastewaters through biological processes. Omega-9 retort wastewater developed considerable turbidity after several days of storage at room temperature. This turbidity was caused by growth of rod-shaped bacterial cells (Farrier and others, 1977). Fox (1978) found that these cells removed significant quantities of potassium, calcium, iron, nickel, copper, zinc, and mercury from retort wastewater. Felix and others (1977) noted significant changes in high-performance, liquidchromatographic fractionation patterns of organic solutes when bacterial growth occurred in retort wastewater. In retort wastewater, it was noted that almost all the thiosulfate was converted to tetrathionate when bacterial growth occurred. Gauger (1981) applied DOC-fractionation analysis to Omega-9 retort wastewater during incubation and found that primarily hydrophobic con- stituents were disappearing from retort wastewater during bacterial growth. The largest decrease occurred in the hydrophobic-neutral fraction.

\section{EFFECTS OF BACTERIAL GROWTH ON DISSOLVED ORGANIC-CARBON CONCENTRATION IN OCCIDENTAL-6 PROCESS AND GAS-CONDENSATE RETORT WASTEWATERS}

The subject study was conducted under a research grant awarded to Dr. Stephen Williams of the University of Wyoming. The two retort wastewaters initially were sterilized by passage through three sterile filter membranes $(1.2-, 0.45-$, and $0.22-\mu \mathrm{m}$ pore size) stacked in series. These sterilized waters were stored in glass containers at $1^{\circ} \mathrm{C}$ for about 6 months before the growth experiments could be made. The results of the growth experiments indicated that significant degradation occurred in some of the samples during storage.

The growth experiments were made in Erlenmeyer flasks in which Occidental-6 retort wastewaters were 


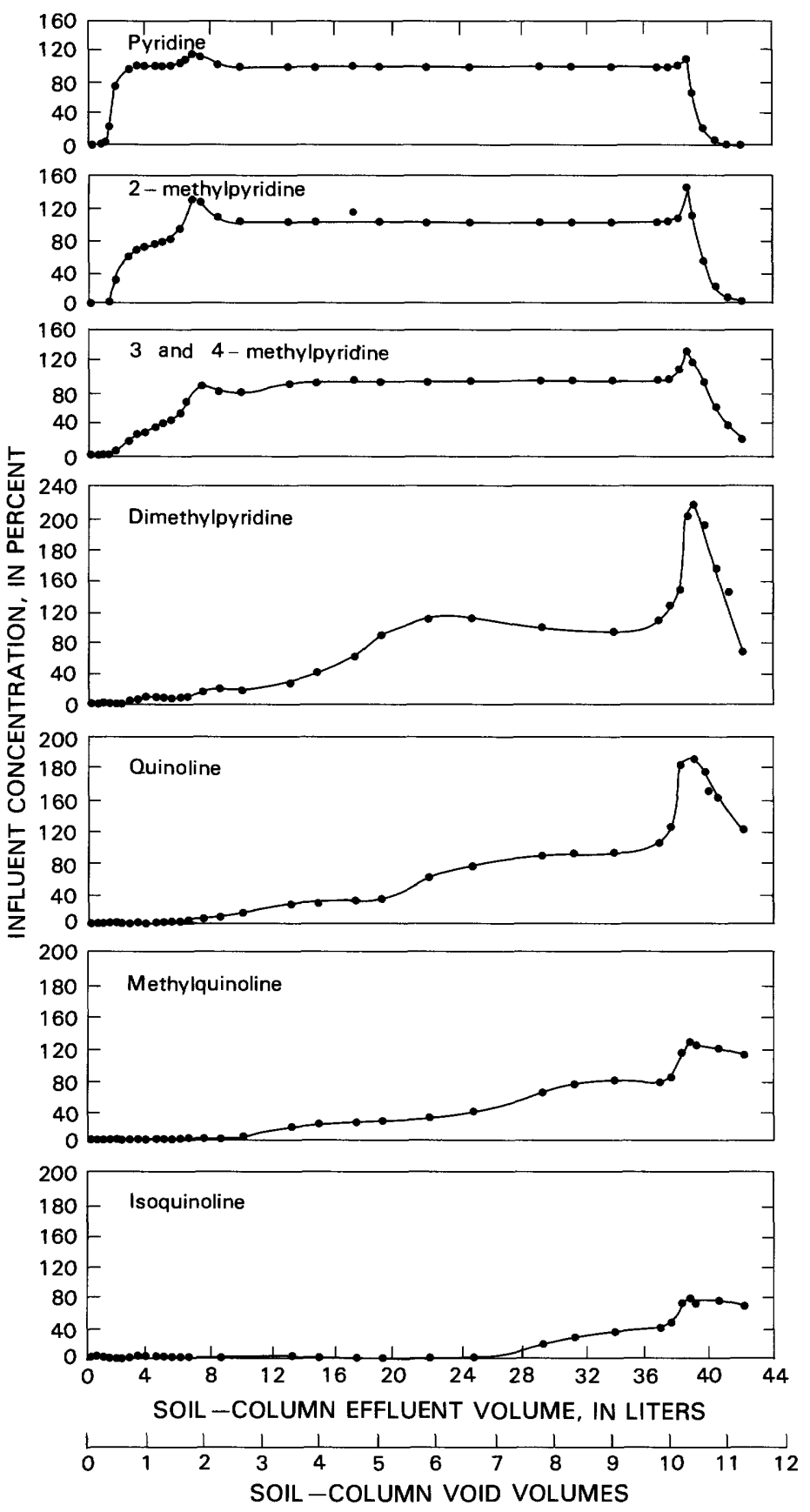

FIGURE 23. - Percentage breakthrough curves for aromatic amines in Omega-9 retort-wastewater leachate (modified from Leenheer and others, 1981).

inoculated with organisms taken from Omega-9 retort wastewater. The samples were incubated at $20^{\circ} \mathrm{C}$ on a rotary shaker, and periodic samples were removed for DOC fractionations and microbial-population determinations. Microbial populations were determined using spread-plate technique on a solid synthetic retortwastewater agar formulation supplemented with ammonium nitrate, dipotassium phosphate, magnesium sulfate, and sodium acetate. Once the plates were spread with a diluted sample aliquot, they were incubated at $25^{\circ} \mathrm{C}$ and counted after 3 days. Three flasks were used in each growth experiment, with two being inoculated and the third used as a control.

Bacterial growth occurred readily in the Occidental- 6 process retort wastewater but could not be established in the Occidental- 6 gas-condensate retort wastewater even after dilution by two, four, and eight times. Bacterial growth curves for flasks I and II of the Occidental-6 process retort wastewater experiment are shown in figures 24 and 25. The growth curves were typical in that the organisms exhibited a brief lag phase, followed by a logarithmic growth phase, and finally a stationary or death phase.

Dissolved organic-carbon fractionation of Occidental-6 process retort wastewaters in flasks II and III at 0,16 , and 32 hours into the growth experiment show that loss of carbon occurred as hydrophobic-acid DOC (table 9). However, the control flask showed the same degree of carbon loss as the inoculated flask, and growth was not observed in the control flask. The Occidental- 6 process retort wastewaters in the inoculated or control flasks probably had degraded at the start of the growth experiments, because the DOC content decreased from $3,000 \mathrm{mg} / \mathrm{L}$ (table 3 ) to 834 to $964 \mathrm{mg} / \mathrm{L}$ (table 9 ). In flask I where DOC fractionation was not made, the DOC concentration was $2,300 \mathrm{mg} / \mathrm{L}$ at the start of the experiment. This variance in DOC must have occurred during the 6-month sample storage after filter sterilization because the three flasks were stored separately. Apparently, some organic solutes in the Occidental-6 process retort wastewater are so readily degraded that the major share of DOC loss occurred during refrigerated storage.

\section{CONCURRENT INDEPENDENT STUDIES OF MICROBIAL DEGRADATION OF ORGANIC SOLUTES IN RETORT WASTEWATERS}

Torpy and others (1982) and Jones and others (1982) recently completed studies of physical- and biologicaltreatment processes designed to remove organic constituents from Occidental- 6 process retort wastewater. Torpy and others (1982) found that use of activated sludge with powdered activated carbon to treat ammoniastripped retort wastewater alleviated many problems related to toxicity and limited biological growth. The powdered activated carbon adsorbed organic constituents such as aromatic amines, which are inhibitory to biological treatment, and was essential to the formation of a settleable floc. Certain organic solutes in Occidental-6 process retort wastewater that neither adsorb on powdered activated carbon nor were biologically degraded were 
TABLE 8.-Comparison of soil- and liquid-chromatographiccolumn capacity factory $\left(k^{\prime}\right)$ for aromatic amines IODS, octadecylsilica|

\begin{tabular}{lccc}
\hline \multicolumn{1}{c}{ Compound } & $\begin{array}{c}\text { Soil-column } \\
k^{\prime}\end{array}$ & $\begin{array}{c}\text { ODS-column } \\
k^{*}\end{array}$ & $\begin{array}{c}\text { ODS-column } k^{\prime} / \\
\text { soil-column } k^{\prime}\end{array}$ \\
\hline Pyridine & 0.33 & 1.04 & 3.15 \\
2-methylpyridine & .43 & 1.58 & 3.69 \\
3- and 4-methylpyridine & 1.46 & 1.81 & 1.24 \\
Dimethylpyridine & 4.05 & 2.38 & .59 \\
Quinoline & 5.39 & 2.95 & .55 \\
Methylquinoline & 7.03 & 3.42 & .49 \\
\hline
\end{tabular}

oxygenated, unsaturated nitrogen heterocyclic compounds. The most biodegradable constituents were fatty acids, which were removed almost completely by the activated-sludge treatment.

The study by Jones and others (1982) came to the same conclusions as the previous study regarding biodegradable and refractory organic constituents in retort wastewater. The study found that TOSCO-II spent shale could be used as well as powdered activated carbon to remove biologically refractory constituents. Ultraviolet irradiation, ozonation, and chemical oxidants had few beneficial effects in promoting subsequent biological degradation of refractory retort-wastewater constituents. Steam stripping of ammonia and hydrogen sulfide had beneficial effects on biodegradation of organic constituents. The major limiting nutrient for microbial growth in retort wastewater initially was phosphate and then carbon, because much of the DOC is refractory and cannot be used.

\section{CONCLUSIONS}

The results of the microbial-growth studies presented in this section are quite definitive and agree with each other. Much of the dissolved organic carbon in retort wastewaters is refractory or toxic or both, which limits microbial growth. Aromatic amines seem to be the most refractory class of compounds and they need to be removed by adsorption or steam stripping before growth can occur using compounds such as fatty acids as carbon sources. Thus, it is not surprising that bacterial growth occurs in Occidental- 6 process retort wastewater that contains abundant fatty acids and that is deficient in aromatic amines. In contract, growth does not occur in Occidental- 6 condensate retort wastewater that contains large concentrations of aromatic amines (table 3). Aromatic amines released by oil-shale retorting have been found to persist for several years in soils adjacent to a

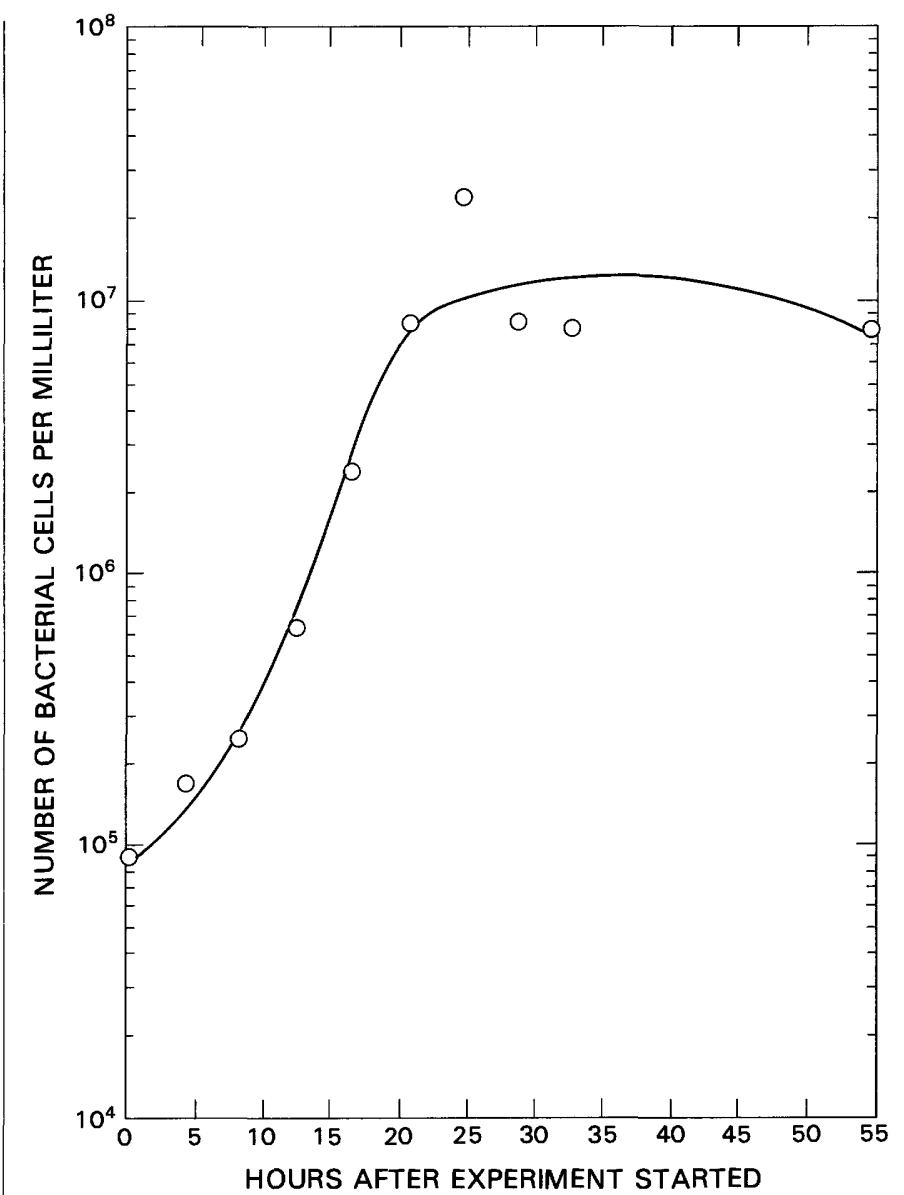

FIGURE 24.-Growth curve of microorganisms in inoculated flask I, Occidental-6 process retort wastewater.

retort (Riley and others, 1981). Therefore, biological treatment of retort wastewaters alone is not sufficient to remove refractory toxic organic constituents from wastewaters, but needs to be combined with physical treatment processes such as adsorption and steam stripping. Aromatic amines may present the greatest problem in retort wastes because of their toxicity, noxious odors, and persistence in the environment.

\section{SITE STUDIES OF EFFECTS ON WATER QUALITY FROM OILSHALE RETORTING}

Most of the site studies involving water-quality effects of oil-shale retorting were performed at the in-situ retorting site of the Laramie Energy Technology Center, U.S. Department of Energy. This site was located approximately midway between Green River and Rock Springs, Wyoming. Two major studies were made at this site: (1) Changes in chemical constituents with time in monitoring wells surrounding the site- 9 retort after this retort was burned; and (2) a first-order soil survey of the entire in-situ retorting site to determine the chemical and physi- 


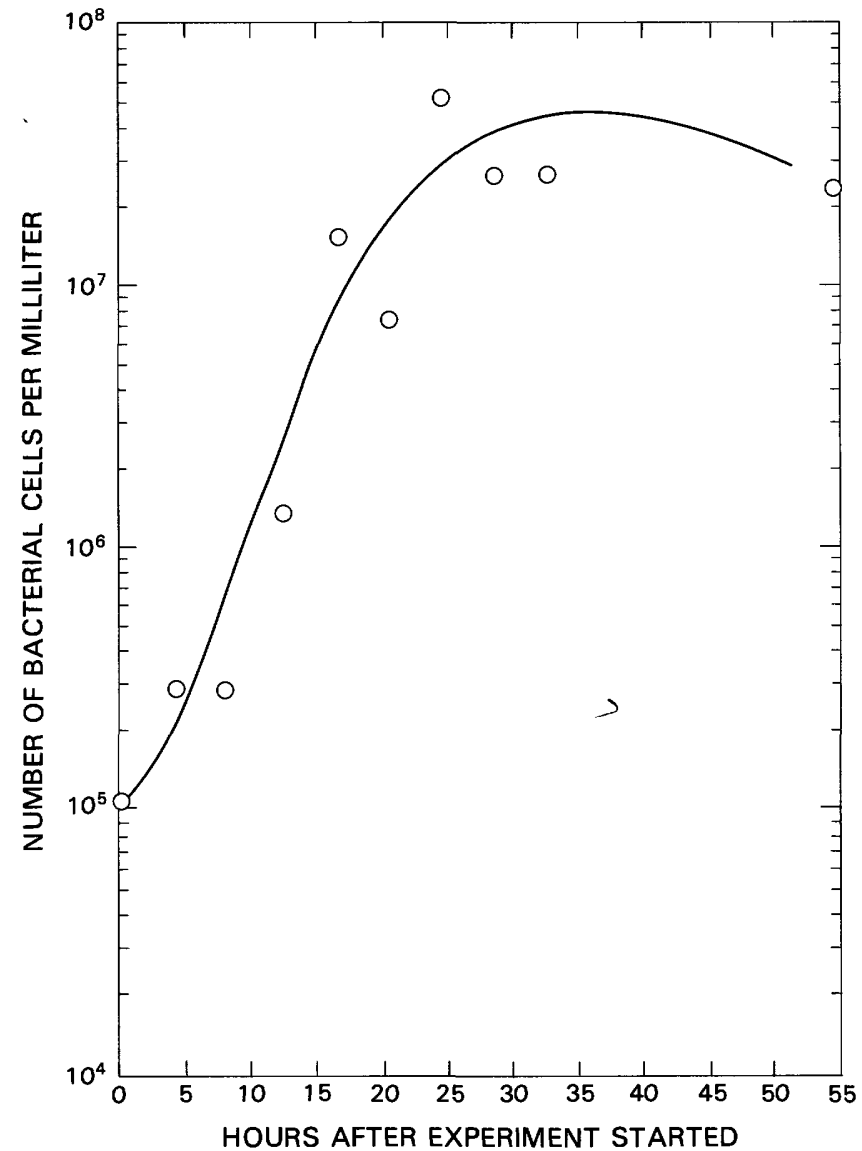

FIGURE 25.-Growth curves of microorganisms in inoculated flask II, Occidental- 6 process retort wastewater.

cal characteristics of the soils that might be affected after a retort-wastewater spill.

After the Rock Springs site studies, modified in-situ retorting and its effects on ground water were studied at the Rio Blanco Oil Shale Corporation retorts located in Piceance Basin, Colorado, on leased tract C-a. The goals of this latter study were to determine vapor-phase transport processes of volatile retort-wastewater constituents into ground water during retorting and to study the natural organic-solute composition of ground waters found in oil shale.

\section{EFFECTS OF EXPERIMENTAL IN-SITU RETORTING ON GROUND WATER NEAR ROCK SPRINGS, WYOMING}

A map of the in-situ retorting site near Rock Springs, Wyoming, is shown in figure 26 , and the wells at site 9 are shown in figure 27. Details of well construction and water chemistry are given in a report by Jackson and others (1975). The pattern wells at site 9 used for insitu retorting operations are all about $80 \mathrm{~m}$ deep whereas the observation wells range from 73 to $93 \mathrm{~m}$ in depth with the exception of well $0-1$, the project water-supply well, which is $382 \mathrm{~m}$ deep. Major constituents in the ground water are sodium, bicarbonate, sulfate, and chloride. The dissolved-solids concentrations are extremely variable, ranging from 1,100 to $44,900 \mathrm{mg} / \mathrm{L}$. Organic-constituent concentrations also are extremely variable, with total organic-carbon concentrations ranging from undetectable to $1,890 \mathrm{mg} / \mathrm{L}$.

The site-9 retort was burned from April to October 1976 (Long and others, 1977) and 47,933 L of retort wastewater (designated Omega-9) were collected, filtered, and stored under refrigeration (Farrier and others, 1977). Various pattern and observation wells that remained operational after retorting were sampled during May

TABLE 9.-Dissolved organic-carbon fractionation of sample removed at start of microbial growth in Occidental- 6 process retort wastewater, and at 16 and 32 hours after start of experiment

[Data are for an inoculated flask (flask II) and an uninoculated flask (flask III), reported in milligrams of carbon per liter]

\begin{tabular}{|c|c|c|c|c|c|c|}
\hline \multirow{3}{*}{ Organlc-carbon fraction } & \multicolumn{6}{|c|}{ Hours since inoculation } \\
\hline & \multicolumn{2}{|c|}{0} & \multicolumn{2}{|c|}{16} & \multicolumn{2}{|c|}{32} \\
\hline & Inoculated & Control & Inoculated & Control & Inoculated & Control \\
\hline Total dissolved-organic carbon & 904 & 834 & 755 & 726 & 720 & 806 \\
\hline Hydrophob1c total & 236 & 388 & 333 & 270 & 265 & 290 \\
\hline Hydrophobic acids & 113 & 232 & 3 & 5 & 0 & 1 \\
\hline Hydrophobic bases & 75 & 53 & 69 & 81 & 72 & 84 \\
\hline Hydrophobic neutrals & 48 & 103 & 261 & 184 & 193 & 205 \\
\hline Hydrophilic total & 728 & 445 & 422 & 456 & 455 & 515 \\
\hline Hydrophilic acids & 582 & 90 & 198 & 160 & 380 & 336 \\
\hline Hydrophilic bases & 54 & 157 & 167 & 182 & 54 & 125 \\
\hline Hydrophilic neutrals & 92 & 198 & 57 & 114 & 21 & 54 \\
\hline
\end{tabular}




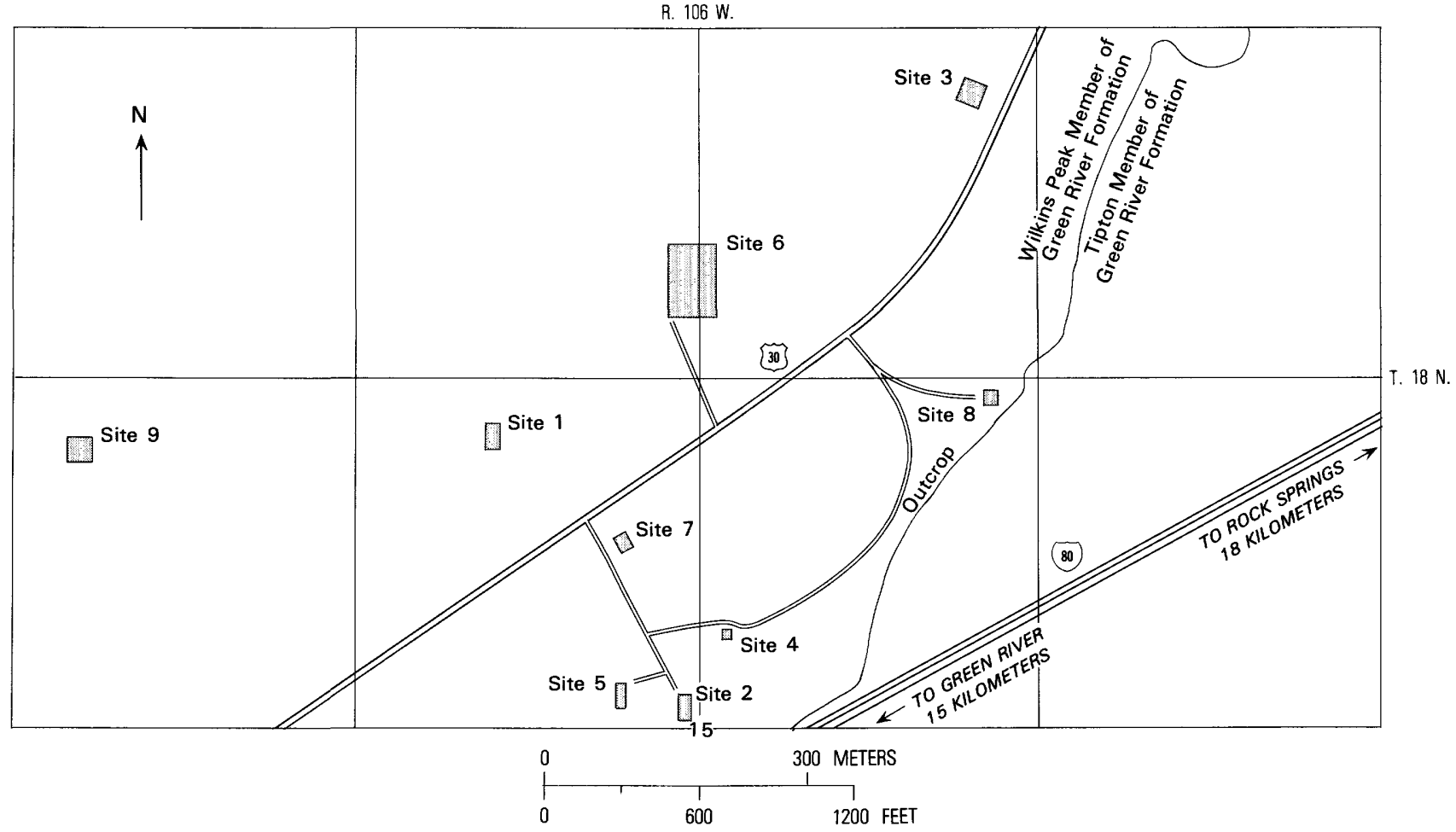

FIGURE 26. - Location of experimental in-situ retorting sites near Rock Springs, Wyoming (modified from Jackson and others, 1975).

1977, October 1977, and September 1977. Changes in organic-solute composition of ground water were monitored by DOC fractionation, and the results are shown in table 10.

The following conclusions can be made from the data in table 10:

1. Organic contaminants in ground water from the pattern wells were detected by changes in DOC-fractionation patterns, especially by increases in the hydrophobic- and hydrophilic-base fractions that are almost absent from native ground water. Retort-wastewater contamination of ground water was not always evidenced by increases in DOC concentration because of the highly variable DOC concentrations in native ground water shown by the observation-well analyses.

2 . Water from pattern wells on the eastern side of the retort-9 well pattern have smaller concentrations of organicbase contaminants than does water from the remaining wells of the pattern.

3. Organic-base contaminants generally decrease with time in water from the pattern wells and hydrophobicacid concentrations generally increase because of the incursion of native ground water containing significant quantities ( 50 percent) of hydrophobic acids.

4. Evidence of organic contamination in water from observation wells was not detected 1 year after the retort was burned.
5. The average DOC-fractionation pattern of water from the observation wells is similar to the DOCfractionation pattern of a black "trona water" reported previously (Leenheer and Huffman, 1976). This fractionation pattern can be regarded as typical for kerogen from the Green River Formation extracted by alkaline carbonatetype ground waters.

6. The DOC concentration of Bitter Creek, flowing near the southern boundary of the site, is much less than DOC concentrations in ground waters in contact with oil shale, and its DOC-fractionation pattern is typical of surface waters of this region (Stuber and Leenheer, 1978b).

Because of the tendency of retort-wastewater constituents to sorb on some aquifer solids and to degrade chemically and biologically, a few major constituents largely unique to retort wastewater were determined quantitatively to determine the persistence of these constituents. The results are shown in table 11 (Stuber and others, 1978).

During the 1-year post-retorting period, thiosulfate and tetrathionate were removed quantitatively from retort wastewater, probably by chemical and biological redox processes. Sorption was not significant as shown by the previous soil-column studies. The mean concentrations of thiocyanate and ammonium are approximately one order of magnitude less than in Omega-9 water as shown in table 11. Dilution of these wastes by inflow of ground 


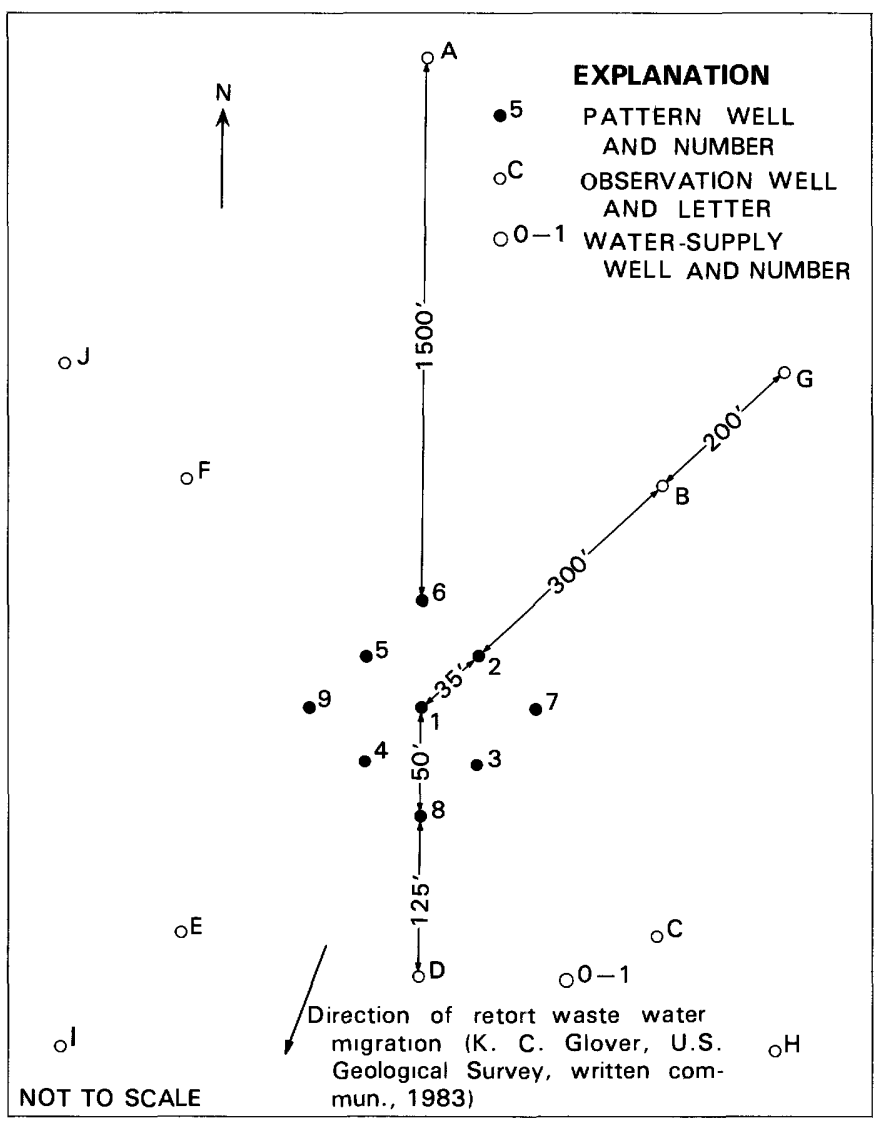

FIGURE 27. - Wells at the site-9 in-situ retorting experiment near Rock Springs, Wyoming (modified from Jackson and others, 1975).

water, by diffusion, and by pumping are factors contributing to a general decrease in waste-solute concentrations. The ratio of the mean concentration of thiocyanate to the mean concentration of ammonium in the wells sampled during October 1977 is very close to the ratio of these constituents in Omega-9 retort wastewater, indicating that these two constituents, which are unique to retort wastewater, probably are not being degraded by biological, oxidative, or sorptive processes, which would likely change the ratio. Ammonium tends to be rapidly sorbed by cation exchange; therefore, the spent shale in the in-situ retort must have a small cation-exchange capacity for ammonium to persist. Thiocyanate probably is the best indicator for retort-wastewater contamination because of its conservative nature and stability.

A current study (K.C. Glover, U.S. Geological Survey, written commun., 1984) has found that retort wastewater has migrated about $0.8 \mathrm{~km}$ south of site 9 in the Wilkens Peak Member of the Green River Formation, a sandstone that overlies the Tipton Shale Member of the Green River Formation, in which retorting occurred. Thiocyanate was used in this study to monitor waste migration.

\section{SOIL SURVEY OF IN-SITU RETORTING SITE NEAR ROCK SPRINGS, WYOMING}

A soil survey of the in-situ oil-shale retorting site near Rock Springs, Wyoming, was made by Woodward-Clyde Consultants (1978). Results of the soil survey are shown on the soils map (fig. 28). Soil series found on the undulating uplands were Horsley clay loam, Haterton loam, Terada loamy fine sand, and Monte fine sandy loam. These soil series have moderate to high permeabilities so that a wastewater spill most likely would infiltrate these soils before running off into Bitter Creek. The Horsely and Haterton soil series are shallow $(15$ to $51 \mathrm{~cm}$ ) and are underlain with weathered and factured oil shale in the Green River Formation that readily receives ground water that infiltrates through the soil profiles. The Terada and Monte soil series are deeper ( 76 to $152 \mathrm{~cm}$ ), and alkaline carbonates tend to accumulate in the underlying subsoils. The dissolved-solids concentration of the ground water underlying these soils probably results from variable leaching of these alkaline carbonates from soils into isolated vertical fractures so that there is limited mixing of adjacent ground waters depending on the fracture pattern. The Terada and Monte series have topsoils that are suitable for salvage to reclaim mining-operation sites.

The lowland alluvial soils adjacent to Bitter Creek southeast and southwest of the site have poor to moderate permeabilities because of extensive clay and sodium content, which expands clay minerals and restricts permeability. These are deep deposits and bedrock was not detected at the maximum depth $(152 \mathrm{~cm})$ of the model-pedon sampling pit. Wastewaters discharged on these alluvial deposits would have a good probability of discharging into Bitter Creek because of its proximity and the restricted permeability of these soils.

The various soil series were sampled by horizon at the model-pedon location and laboratory analyses were made for calcium, magnesium, sodium, potassium, cationexchange capacity, organic carbon, total kjeldahn nitrogen, ammonia nitrogen, phosphate, electrical conductivity, equivalent calcium carbonate, selenium, boron, molybdenum, lead, arsenic, and particle-size distribution. Most soils were alkaline ( $\mathrm{pH} 7.4$ to 8.6 ), contained 0.5 to 2.0 percent organic carbon, and had small nitrogen and phosphorous contents, which would make these soils relatively infertile. The lowland 13 series soils also had significant salinities (electrical conductivities of 8 to $27 \mathrm{mS} / \mathrm{cm}$ ) which limited plant growth. Boron in certain horizons of the Haterton soils series almost equaled or exceeded the toxicity limit of $10 \mathrm{ppm}$ for most plants. All other constituents were within normal expected ranges.

According to Woodward-Clyde Consultants (1978), the soil survey indicated soils of little agricultural value except for grazing. Several of the soils were so shallow or 
TABLE 10. - Dissolved organic-carbon fractionations of various waters sampled at and near experimental in-situ retorting site 9 near Rock springs, Wyoming

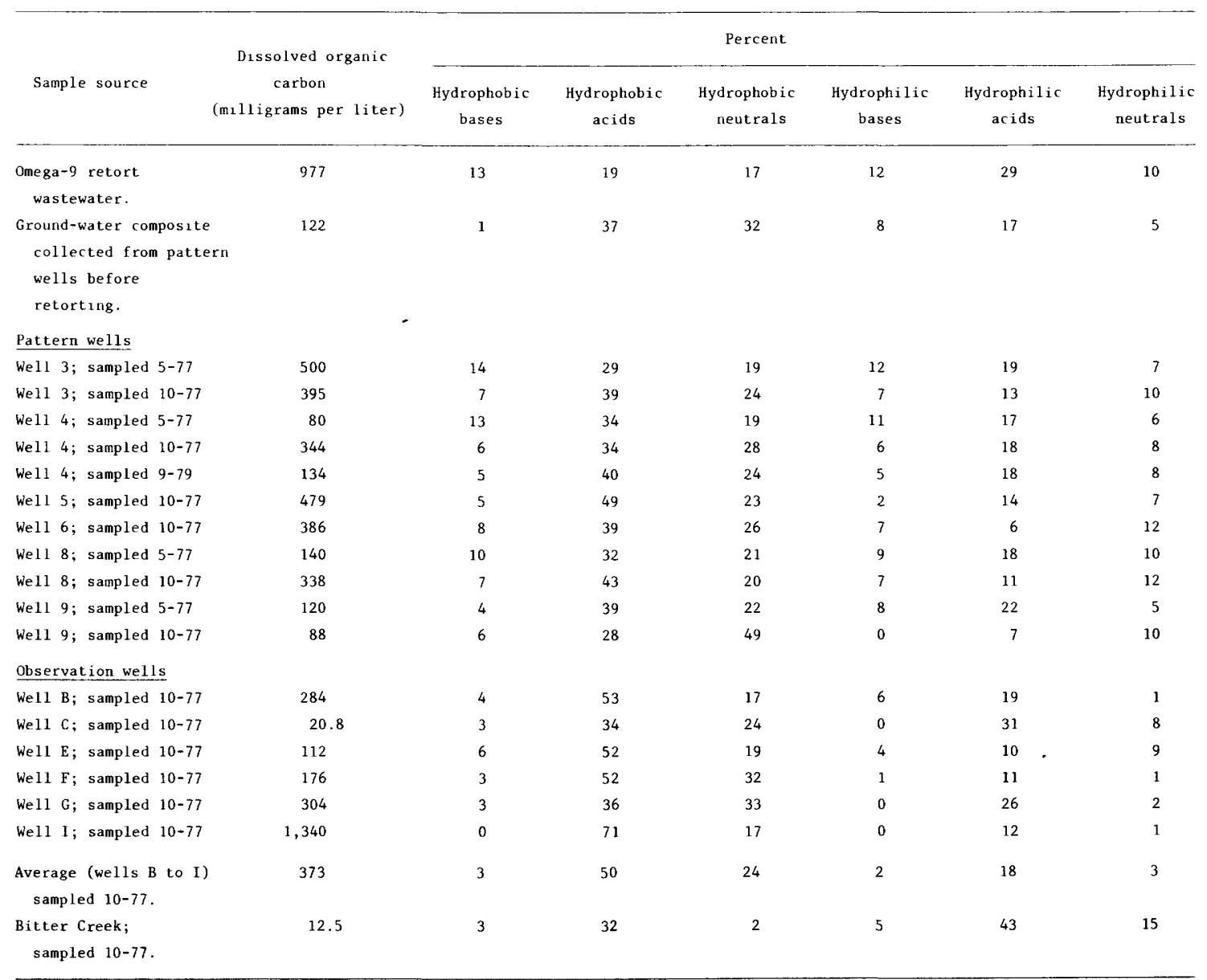

TABLE 11.-Concentration of thiocyanate, thiosulfate and tetrathionate, and ammonia in water from site-9 wells near Rock Springs, Wyoming

\begin{tabular}{|c|c|c|c|}
\hline $\begin{array}{c}\text { Sample } \\
(10-18-77)\end{array}$ & $\begin{array}{l}\text { Thiocyanate } \\
\text { as sulfur } \\
\text { (milligrams } \\
\text { per liter) }\end{array}$ & $\begin{array}{l}\text { Thiosulfate } \\
\text { and } \\
\text { tetrathionate } \\
\text { as sulfur } \\
\text { (milligrams } \\
\text { per liter) }\end{array}$ & $\begin{array}{l}\text { Ammonium } \\
\text { (miliıgrams } \\
\text { per Iiter) }\end{array}$ \\
\hline Omega-9 & 75 & 1,350 & 4,880 \\
\hline We1l 3 & 8.8 & 0 & 421 \\
\hline Well 4 & 2.2 & 0 & 283 \\
\hline Well 5 & 8.4 & 0 & 221 \\
\hline Well 6 & 8.8 & 0 & 335 \\
\hline Well 8 & 4.4 & 0 & 446 \\
\hline Well 9 & 0 & 0 & 30 \\
\hline
\end{tabular}

so alkaline that they could not be used for mine reclamation, and this may indicate a potential problem for oil-shale development and restoration in certain areas. Retort wastewaters discharged in soils located on undulating upland areas most likely will rapidly infiltrate these permeable soils and enter the vertical fractures of underlying oil shale, whereas retort wastewaters discharged on the sodic lowland alluvial soils will either pool and evaporate or will run off into Bitter Creek, which discharges into the Green River.

\section{RIO BLANCO MODIFIED IN-SITU RETORT SITE, PICEANCE CREEK BASIN, COLORADO}

From April 1981 through November 1982, native ground water and ground water that leaked into retort 1 of the Rio Blanco Oil Shale Corporation were sampled to characterize their composition before, during, and after the burning of the retort. The purposes of this study were to characterize the organic-solute composition of native 


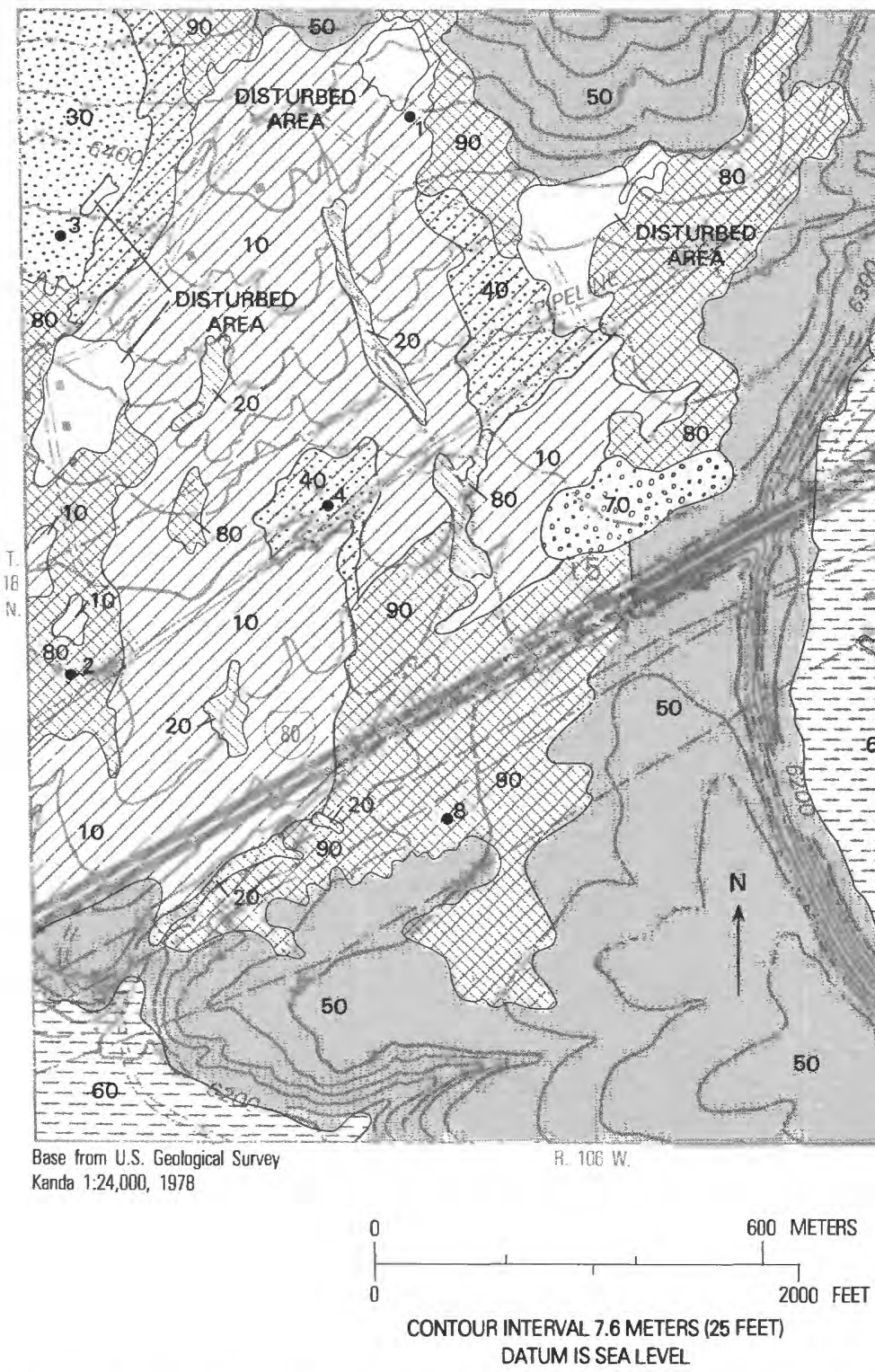

FIGURE 28. - Soil map of experimental in-situ retorting site near Rock Springs, Wyoming (modified from Woodward-Clyde Consultants, 1978).

ground waters (discussed in the next section of this report) and to determine the transport processes that move wastes from the retorting process into ground water during retorting.

Most of the ground water initially present in the retort area was removed by wells and pumps in mine workings surrounding the retort. Residual waters that infiltrated the various mine workings and shafts surrounding the retort were pumped from a sump in the main shaft to a lined holding pond. This ground water that infiltrated the retort area was sampled from the SUB-E mine sump before the retort burn. During the burn, personnel from the Rio Blanco Oil Shale Corporation periodically monitored the sump water for constituents such as ammonium,
EXPLANATION MAPPING-UNIT NAME

HORSELY CLAY LOAM, 3 to 9 -percent slopes

20 HATERTON LOAM, 3 to 6 -percent slopes

TERADA LOAM FINE SAND, 3

to 9 -percent slopes

MONTE FINE SANDY LOAM, STRONGLY ALKALINE PHASE 3 to 8 -percent slopes

50. ROCK OUTCROP

EE- "13" CLAY LOAM, 0 to 3percent slopes

OOOA. "13" LOAM, COARSE-LOAMY PHASE, $O$ to 3 -percent slopes "13" CLAY LOAM, FINE PAHSE 0 to 3 -percent slopes RECLAIMED GRAVEL PIT

HORSELY - HATERTON COMPLEX, 0 to 6 - percent slopes HORSELY -ROCK OUTCROP COMPLEX, 6 to $40-$ percent slopes

-1 MOdAl - PEDON LOCATION AND NUMBER which would indicate retort contamination of ground water adjacent to the retort. No contamination was detected, so there was no intensive sampling for retort constituents during the burn. The retort was designed to burn under negative air pressure relative to the mine workings and shafts in order to contain combustion products within the retort. Apparently, this design was successful in minimizing contact of retort wastes with mine water during the burning of retort 1.

Chemical analyses of ground-water samples collected from discharges at fractures in the SUB-E development level and from two of the dewatering wells are presented in table 12. Only minor variations were detected between samples. 
TABLE 12.-Chemical analyses of ground waters sampled May 5, 1981, Rio Blanco retort site, Piceance Creek Basin, Colorado

[Data in milligrams per liter except as indicated: $\mu \mathrm{S}$ at $25^{\circ} \mathrm{C}$, microsiemens per centimeter at $25^{\circ}$ Celsius ]

\begin{tabular}{|c|c|c|c|c|c|c|c|c|c|}
\hline Determination & SUB-E1 & SUB-E2 & SUB-E3 & SUB-E4 & SUB-E5 & SUB-E6 & SUB-E7 & Wel1 D-6 & Well D-8 \\
\hline $\begin{array}{l}\text { Specific conductance } \\
\left.\text { ( } \mu \text { S at } 25^{\circ} \mathrm{C}\right)\end{array}$ & 935 & 820 & 791 & 746 & 731 & 820 & 835 & $\cdots$ & 1,370 \\
\hline Dissolved organic carbon & 4.6 & 3.5 & 3.5 & 4.5 & 2.5 & 4.1 & $\cdots$ & 1.8 & 2.8 \\
\hline pH (units) & 7.8 & 8.0 & 7.7 & 8.0 & 7.9 & 8.3 & 7.9 & -- & 7.9 \\
\hline Calcium & 48 & 33 & 34 & 31 & 15 & 35 & 36 & 45 & 55 \\
\hline Magnesium & 99 & 87 & 84 & 65 & 50 & 80 & 78 & 58 & 89 \\
\hline Sodium & 180 & 190 & 190 & 190 & 210 & 190 & 200 & 200 & 180 \\
\hline Potassium & .5 & .3 & .3 & .3 & .3 & .3 & .4 & .3 & .3 \\
\hline Bicarbonate & 573 & 542 & 617 & 544 & 461 & 576 & 550 & 524 & 649 \\
\hline Sulfate & 425 & 399 & 318 & 294 & 311 & 356 & 384 & 363 & 375 \\
\hline Chloride & 8.3 & 9.4 & 7.3 & 8.8 & 21.2 & 7.4 & 8.6 & 7.2 & 8.4 \\
\hline Ammonium as nitrogen & 0 & .28 & .10 & 0 & .24 & 0 & 0 & .01 & .15 \\
\hline
\end{tabular}

During October 1982, breakdown of pumps that dewater the mine enabled native ground water to partly backflood the retort. On November 19, water samples from the retort-sump discharge to a lined evaporation pond, and from the pond to which the retort-sump wastewater was being discharged, were collected by D.J. Hayes of the U.S. Geological Survey office in Meeker, Colorado, and by G. A. Miller from the U.S. Bureau of Land Management Oil Shale office in Grand Junction, Colorado, and were sent to the author's laboratory for analyses. The samples were completely analyzed within 2 weeks of receipt because biological degradation and chemical oxidation would cause changes with time of important constituents even under refrigerated storage. Inorganic analyses were made by the U.S. Geological Survey's water-quality laboratory in Denver, Colorado, by methods adapted to oil-shale retort wastewater (Leenheer and others, 1981) and organic analyses were made in the author's laboratory by methods developed specifically for retort wastewaters (Leenheer and others, 1982). Organic constituents also were identified and confirmed by gas chromatography-mass spectrometry performed in the water-quality laboratory.

Inorganic analyses of the water sampled November 19, 1982 , from the evaporation pond containing retort-sump wastewater and freshly discharged water from the sump of retort 1 are shown in table 13. Pond water had a lower specific conductance (and dissolved-solids concentration) than the retort-sump wastewater because retort-sump wastewater discharged into the pond was diluted by a large volume of native ground water that infiltrated the retort and was previously discharged into the pond; chemistry of native ground water is shown in table 12 .
TABLE 13.-Inorganic analyses of wastewaters sampled November 19, 1982, from backflooded Rio Blanco retort 1, Piceance Creek Basin, Colorado

$[\mu \mathrm{g} / \mathrm{L}$, micrograms per liter; mg/L, milligrams per liter; $\mu \mathrm{S}$, microsiemens per centimeter at $25^{\circ}$ Celsius]

\begin{tabular}{|c|c|c|c|}
\hline Constituent & Units & $\begin{array}{l}\text { Discharged retort- } \\
\text { sump wastewater }\end{array}$ & $\begin{array}{l}\text { Water from } \\
\text { evaporation pond } \\
\text { containing retort- } \\
\text { sump water }\end{array}$ \\
\hline Barium & $\mu \mathrm{g} / \mathrm{L}$ & 68 & 68 \\
\hline Beryllium & $\mu g / L$ & 2.7 & 1.8 \\
\hline Cadmium & $\mu g / L$ & $<3$ & $<3$ \\
\hline Calcium & $\mathrm{mg} / \mathrm{L}$ & 160 & 110 \\
\hline Coba1t & $\mu g / L$ & $<9$ & $<9$ \\
\hline Copper & $\mu \mathrm{g} / \mathrm{L}$ & $<30$ & $<30$ \\
\hline Hardness & $\mathrm{mg} / \mathrm{L}$ & 820 & 650 \\
\hline Iron & $\mu g / L$ & 320 & 370 \\
\hline Lead & $\mu \mathrm{g} / \mathrm{L}$ & $<30$ & $<30$ \\
\hline Lithium & $\mathrm{Hg} / \mathrm{L}$ & 1,900 & 750 \\
\hline Magnesium & $\mathrm{mg} / \mathrm{L}$ & 100 & 90 \\
\hline Manganese & $\mu g / L$ & 47 & 54 \\
\hline Molybdenum & $\mu g / L$ & 600 & 260 \\
\hline Nitrogen $\left(\mathrm{NH}_{4}\right.$ as $\left.\mathrm{N}\right)$ & $\mathrm{mg} / \mathrm{L}$ & 14 & 12 \\
\hline Nitrogen $\left(\mathrm{NH}_{4}\right.$ as $\left.\mathrm{NH}_{4}\right)$ & $\mathrm{mg} / \mathrm{L}$ & 18 & 15 \\
\hline $\mathrm{pH}$ & & 8.2 & 8.2 \\
\hline Silica & $\mathrm{mg} / \mathrm{L}$ & 25 & 25 \\
\hline Sodium & $\mathrm{mg} / \mathrm{L}$ & 400 & 290 \\
\hline Specific conductance & $\mu \mathrm{S}$ & 3,650 & 2,590 \\
\hline Strontium & $\mu g / L$ & 7,500 & 7,300 \\
\hline Vanadium & $\mu g / L$ & $<18$ & $<18$ \\
\hline Zinc & $\mu g / L$ & 47 & 38 \\
\hline \multicolumn{4}{|l|}{ Sulfur species } \\
\hline Total sulfur & $\mathrm{mg} / \mathrm{L}$ & 530 & 310 \\
\hline Thiocyanate & $\mathrm{mg} / \mathrm{L}$ & .9 & 1.2 \\
\hline Thiosulfate & $\mathrm{mg} / \mathrm{L}$ & $<1$ & $<1$ \\
\hline Tetrathionate & $\mathrm{mg} / \mathrm{L}$ & $<2$ & $<2$ \\
\hline Sulfate & $\mathrm{mg} / \mathrm{L}$ & 530 & 310 \\
\hline
\end{tabular}


Inorganic constituents and physical properties that had significant increases in the retort-sump wastewater compared to background values in native ground water were calcium, ammonium, sodium, specific conductance, and thiocyanate, which is not found in natural waters.

Ammonium concentrations are affected by biological uptake and cation-exchange effects, and calcium, lithium, and sodium are affected by cation-exchange interactions. Calcium and hardness concentrations are dependent on calcining of carbonate minerals and surface chemistry changes of spent shale during retorting. The absence of thiosulfate and tetrathionate in both the retort-sump and pond wastewaters probably indicate their oxidation to sulfate by sulfur-oxidizing bacteria that are known to be present in the access levels and shafts adjacent to the retort.

Organic analyses of the Rio Blanco retort-sump and pond wastewaters are shown in table 14 . The organicwaste constituents in these wastewaters are similar to constituents in the retort wastewaters from the Occidental-6 retort at Logan Wash, Colorado, except that the more soluble and volatile constituents are depleted in the Rio Blanco wastewaters. Most likely these soluble and volatile constituents were removed in retort wastewaters produced during the burn, and the remaining organic constituents with lesser solubility and volatility are now being leached from the spent shale and unrecovered shale oil.

Biological degradation of organic acids and phenols occurred in the pond water prior to the sampling on November 19. Phenols and dicarboxylic acids degraded at a faster rate than aliphatic and aromatic monocarboxylic acids, as shown by concentration differences between retort-sump and pond wastewaters in table 14. Phenols degrade by both aromatic-ring cleavage and enzymatic oxidative-coupling mechanisms, with the degradation rate being directly related to phenol solubility. Residual concentrations of phenols found in the pond water reflect the microbial degradation rates published for these phenols (Pitter, 1975).

Aliphatic acids degrade through coenzyme-A conjugates with the carboxyl group in Kreb's-cycle oxidation. Dicarboxylic acids have twice as many carboxyl-group sites of attack for biological oxidation as monocarboxylic acids, thus they degrade at a faster rate (table 14). Aliphatic-monocarboxylic acids are degraded successively into two-carbon fragments that are converted into acetyl coenzyme $\mathrm{A}$ until a three-carbon chain is obtained; this chain is converted into propionyl coenzyme $\mathrm{A}$, which degrades through a slower metabolic pathway. The nearly equivalent concentrations of propanoic and 2-methylpropanoic acid concentrations in the retort-sump and pond wastewaters show the effect of the slower degradation rate of the propionyl coenzyme-A pathway com- pared to the acetyl coenzyme-A pathway, which is operative with the other aliphatic-monocarboxylic acids.

Aromatic amines are not significantly affected by biological degradation, and therefore, their relative concentration is much greater than the organic acids in the pond wastewater. The more soluble, lower molecularweight aromatic amines are more enriched in the pond wastewater than the retort-sump wastewater, which may indicate that concentrations of conservative constituents were much greater in wastewaters pumped from the backflooded retort prior to the November 19th sampling of the retort-sump wastewater.

The DOC-fractionation data clearly have a retortwastewater signature with large percentages of organic bases, but it does not show the effects of biological degradation of acids and phenols in the pond wastewater. Apparently, degradation products such as humic and fulvic acid are a part of the same compound classes as the acid precursors, and a significant shift in the data does not occur.

\section{CONCLUSIONS}

No migration of retort wastes to adjacent ground waters during the retort burn was detected at either the Rock Springs or the Rio Blanco sites; no migration for as much as 2 years after the burn was detected at the Rock Springs site. However, a recent study (K.C. Glover, U.S. Geological Survey, written commun., 1984) found significant waste migration at the Rock Springs site after backflooding of the retort by native ground water was completed. Backflooding of water toward the dewatered retort at the Rock Springs site, mine dewatering, and burning the retort under a negative pressure differential at the Rio Blanco site were factors that prevented subsurface migration of retort wastes. No vapor-phase transport of organic contaminants to native ground water was detected during burning of Rio Blanco retort 1 , and water contaminated during partial backflooding of retort 1 after the burn was removed from the retort and contained in a lined evaporation pond. Analyses of wastewaters pumped from Rio Blanco retort 1 indicate that significant quantities of retort contaminants are released into water from spent shale and unrecovered shale oil when a modified in-situ oil-shale retort is backflooded after retorting.

Subsurface retorting can have a major impact on groundwater hydrology because of creation of a dewatered zone surrounding the retort, creation of a burned retort with different aquifer characteristics, and creation of liquid and gaseous products and wastes within the retort. Determination of retort-waste migration and ground-water quality changes will be a long-term monitoring effort far beyond the time-scale of this project, because of the long 
TABLE 14. - Organic analyses of wastewaters sampled November 5, 1982, from backflooded Rio Blanco retort 1, Piceance Creek Basin, Colorado

$[\mu \mathrm{g} / \mathrm{L}$, micrograms per liter; ND, not detected; NA, not analyzed; mg/L, milligrams per liter

\begin{tabular}{|c|c|c|}
\hline Compound & $\begin{array}{c}\text { Discharged retort- } \\
\text { sump wastewater } \\
(\mu g / \mathrm{L})\end{array}$ & $\begin{array}{c}\text { Water from } \\
\text { evaporation pon } \\
\text { contanining retort } \\
\text { sump wastewates } \\
(\mu \mathrm{g} / \mathrm{L})\end{array}$ \\
\hline
\end{tabular}

Aliphatic-monocarboxylic acids

Acetic acrd ${ }^{1}$

Propanoic acid ${ }^{1}$

2-Methylpropanoic acid ${ }^{1}$

Butanoic acid ${ }^{1}$

2-Methylbutanoic acid ${ }^{2}$

3-Methylbutanoic acid ${ }^{2}$

Pentanoic acid ${ }^{1}$

C-6 acid isomers ${ }^{2}$

Hexanoic acid ${ }^{1}$

C-7 acid isomers ${ }^{2}$

Hepanoic acid ${ }^{1}$

C-8 acid isomers ${ }^{2}$

Octanoic acid ${ }^{1}$

C-9 acid isomers ${ }^{2}$

Nonanoic acid ${ }^{1}$

C-10 acid isomers ${ }^{2}$

Decanoic acid ${ }^{1}$

C-11 acid isomers ${ }^{2}$

Aliphatic-monocarboxylic acids

Tridecanoic acid ${ }^{2}$

Tetradecanoic acid ${ }^{2}$

Pentadecanoic acid ${ }^{2}$

9-Hexadecenoic acid ${ }^{2}$

Hexadecanolc acid ${ }^{2}$

Hepatadecanoic acid ${ }^{2}$

9-Octadenoic acid ${ }^{2}$

Octadecanoic acid ${ }^{2}$

Aliphatic-dicarboxylic acids

Ethananedioic acid ${ }^{2}$

Propanedioic acid ${ }^{2}$

Pentanedioic acid ${ }^{2}$

C-6 acid isomers ${ }^{2}$

C-7 acid isomers ${ }^{2}$

C-8 acid isomers ${ }^{2}$

C-9 acid isomers ${ }^{2}$

C- 10 acid isomers ${ }^{2}$

Aromatic acids

Benzoic acid ${ }^{2}$

2-Methylbenzoíc acid ${ }^{2}$

Aromatic acids

3-Methylbenzoic acid ${ }^{2}$

4-Methylbenzoic acid ${ }^{2}$

Dimethylbenzoic acid isomers ${ }^{2}$

Trimethylbenzoic acid isomers ${ }^{2}$

Phenols

Phenol

2-Hydroxytoluene

3- and 4-Hydroxytoluene ${ }^{1}$

1,2-Dimethyl-4-Hydroxybenzene ${ }^{1}$

Dimethyl hydroxybenzene 1 somers ${ }^{2}$
TABLE 14.-Organic analyses of wastewaters sampled November 19, 1982, from backflooded Rio Blanco retort 1, Piceance Creek Basin, Colorado-Continued

\begin{tabular}{|c|c|c|}
\hline $\begin{array}{c}\text { Dischar } \\
\text { sump }\end{array}$ & $\begin{array}{l}\text { rged retort- } \\
\text { wastewater } \\
(\mu \mathrm{g} / \mathrm{L})\end{array}$ & $\begin{array}{c}\text { Water from } \\
\text { evaporation pond } \\
\text { containing retort- } \\
\text { sump wastewater } \\
(\mu \mathrm{g} / \mathrm{L})\end{array}$ \\
\hline \multicolumn{3}{|l|}{ Aromatic amines } \\
\hline Aniline ${ }^{2}$ & 83 & 268 \\
\hline Aminotoluene isomers ${ }^{2}$ & 63 & 214 \\
\hline Pyridine ${ }^{1}$ & 68 & 241 \\
\hline 2-Methylpyridine ${ }^{1}$ & 35 & 57 \\
\hline 3- and 4-Methylpyridines ${ }^{1}$ & 36 & 96 \\
\hline 2,6-Dimethylpyridine ${ }^{1}$ & 29 & 54 \\
\hline Dimethylpyridine isomers ${ }^{2}$ & 56 & 122 \\
\hline $\mathrm{C}-3$ alkylpyridine isomers ${ }^{2}$ & 159 & 194 \\
\hline C-4 alkylpyridine isomers ${ }^{2}$ & 151 & 178 \\
\hline \multicolumn{3}{|l|}{ Aromatic amines } \\
\hline C-5 alkylpyridine isomers ${ }^{2}$ & 90 & 85 \\
\hline C-6 alkylpyridine isomers ${ }^{2}$ & 38 & 53 \\
\hline $\mathrm{C}-7$ alkylpyridine 1 somers $^{2}$ & 6 & 7 \\
\hline C-8 alkylpyridine isomers ${ }^{2}$ & 4 & 3 \\
\hline Quinoline ${ }^{1}$ & 7 & 11 \\
\hline Isoquinoline ${ }^{1}$ & 4 & 4 \\
\hline $\begin{array}{l}\text { Methylquinoline and methyl isoquinoline } \\
\text { isomers }^{2}\end{array}$ & 37 & 55 \\
\hline $\begin{array}{l}C-2 \text { alkylquinoline and } \mathrm{C}-2 \text { alkylisoquinoline } \\
\text { isomers }{ }^{2}\end{array}$ & 65 & 96 \\
\hline $\begin{array}{l}\text { C-3 alkylquinoline and } \mathrm{C}-3 \text { alkylisoquinoline } \\
1 \text { somers }^{2}\end{array}$ & 20 & 29 \\
\hline $\mathrm{N}$-phenylbenzeneamine ${ }^{2}$ & 5 & 4 \\
\hline $\mathrm{N}$-phenyl tolueneamine 1 somers ${ }^{2}$ & 15 & 20 \\
\hline Carbazole $^{2}$ & 1 & ND \\
\hline Acridine $^{2}$ & .8 & 1.0 \\
\hline Benzo-f-quinoline ${ }^{2}$ & ND & 1.0 \\
\hline Methylbenzo-f-quinoline isomer ${ }^{2}$ & .7 & ND \\
\hline \multicolumn{3}{|l|}{ Hydroxypridines } \\
\hline 2-Hydroxypyridine ${ }^{1}$ & 57 & $\mathrm{NA}$ \\
\hline 4-Hydroxypyridine ${ }^{1}$ & 3 & NA \\
\hline \multicolumn{3}{|l|}{ Hydroxypyridines } \\
\hline 2-Hydroxy-6-methylpyridine ${ }^{1}$ & 94 & NA \\
\hline
\end{tabular}

Dissolved organic-carbon (DOC) fractionation

\begin{tabular}{lcccc}
\hline Fraction & $\begin{array}{c}\text { Discharged retort- } \\
\text { sump wastewater }\end{array}$ & $\begin{array}{c}\text { Water from evaporation } \\
\text { pond containing retort- } \\
\text { sump wastewater }\end{array}$ \\
\cline { 2 - 3 } & DOC (mg/L) & Percent DOC & DOC (mg/L) & Percent DOC \\
\hline Total DOC & 26.0 & 100 & 30.6 & 100 \\
Hydrophobic bases & 2.0 & 8 & 2.4 & 8 \\
Hydrophobic acids & 4.8 & 20 & 6.2 & 20 \\
Hydrophobic neutrals & 5.0 & 21 & 8.6 & 28 \\
Hydrophilic bases & 3.0 & 13 & 3.0 & 10 \\
Hydrophilic acids & 8.0 & 25 & 7.2 & 24 \\
Hydrophilic neutrals & 3.2 & 13 & 3.2 & 10 \\
\end{tabular}

${ }^{1}$ Identifications confirmed and quantified with standards.

${ }^{2}$ Tentatıve identıfications and quantification only by gas chromatography-mass spectrometry. . 
period required for original ground-water flow patterns to be re-established after retort abandonment. An additional complicating factor will be the very directional nature of waste migration due to fracture flow of ground water.

Monitoring of retort-wastewater constituents within the site-9 retort at Rock Springs and Rio Blanco retort 1 detected rapid degradation of certain reduced sulfur species (thiosulfate and tetrathionate), but thiocyanate persisted and was a tracer to determine retort-wastewater dilution by backflooding ground water. Aromatic amines in the hydrophobic- and hydrophilic-base fractions of DOC fractionation also persisted and can be unique indicators of retort-wastewater contamination.

A soil survey at the Rock Springs site indicated that a wastewater spill on an upland soil would infiltrate fairly rapidly through the soil and underlying fractured shale to the ground water. However, if wastewater spill runoff reached an alluvial soil with significant clay and alkali content, commonly found near watercourses in this region, the spill would either run off or evaporate and the potential for surface-water contamination is much greater.

\section{CHARACTERIZATION OF NATURAL ORGANIC SOLUTES IN WATERS ASSOCIATED WITH OIL SHALE IN THE GREEN RIVER FORMATION}

To determine changes in water quality that occur during development of oil-shale resources, it is necessary to determine the quantity and type of natural organic constituents of ground water because at the mine site, much of the impacting oil-shale wastes also are organic in nature. Distinguishing characteristics of natural and contaminant organic constituents related to oil-shale retorting will be examined in this section of the report. Many of the procedures for both the isolation and characterization were developed specifically for this study because the state of the science for determination of natural organic constituents is not as advanced as for organiccontaminant determinations.

\section{DOC-FRACTIONATION SURVEYS OF SURFACE AND GROUND WATERS}

DOC fractionation was used as a relatively inexpensive reconnaissance tool to define compound-class compositions of natural waters associated with oil shale in the Green River Formation. DOC fractionations of ground waters at the Rock Springs site are shown in table 10; DOC fractionations of surface waters sampled in the White River Basin area of Utah are presented in a report by Stuber and Leenheer (1978b). Summary averages of these and other data sets are shown in table 15. The variability of the DOC fractionations within a data set is represented by standard deviations and coefficients of variation shown in table 16 (Stuber and Leenheer, 1978b).

The DOC fractionations of sets of samples from the White River Basin, Utah, are virtually identical for the two different sampling periods (table 15). However, the variability data for one of these sample sets indicate considerable variability among samples within a set. The published deviations for the standard DOC-fractionation method (Leenheer and Huffman, 1979) exceed the concentrations of hydrophobic and hydrophilic bases and equal the concentration of hydrophobic neutrals found for the data in table 16; thus, variability of these fractions mostly is due to analytical variability. Most of the real variability in table 14 is in the hydrophilic-acid and -neutral fractions. These two fractions contain more biodegradable organic constituents than the hydrophobicacid fraction that contains biologically refractory fulvic acid. The rapid biological conversion processes within the hydrophilic-acid and -neutral fractions, are postulated to be the reason for the variability between samples for this and other surface-water data sets shown in table 25 .

Surface-water samples from the Piceance Creek Basin differ from samples from the White River Basin primarily in the greater hydrophilic-neutral concentration in the Piceance Creek Basin samples. This difference probably is related to sampling date (June) and location, because much of the Piceance Creek Basin water is used for flood irrigation of hay in June, whereas the White River Basin waters sampled for this study largely are unused for irrigation. Plant leachates (such as hay) contain significant percentages ( 40 percent) of polysaccharides that fall into the hydrophilic-neutral fraction (Caine, 1982).

A second interesting trend is the decrease in hydrophilicneutral concentration in the headwater streams of the Piceance Creek Basin (26.6 percent) to Piceance Creek (15.8 percent) to the White River (5.4 percent). This decrease again can be related to decay of biodegradable plant polysaccharides leached by irrigation in headwater regions of the Piceance Creek Basin. The lower DOC in the White River may be partly related to decay of biodegradable organic constituents; the other factor is related to dilution by minimal DOC water from its headwaters in the Flattops region. A White River sample collected in June 1982, $4 \mathrm{~km}$ below Trappers Lake, contained 0.3 $\mathrm{mg} / \mathrm{L}$ DOC.

The ground-water samples shown in table 15 have their own unique fractionation patterns. The DOC fractionations from site-9 near Rock Springs, Wyoming, discussed previously appear to be similar to trona blackwater acids. The ground water sampled from leased tracts in Colorado differs from the Rock Springs samples in that they are from much deeper sources, are much more 
TABLE 15. - Dissolved organic-carbon fractionations of various surface and ground waters associated with oil shale in the Green River Formation

[Data in percent dissolved-organic carbon (DOC); $\mathrm{mg} / \mathrm{L}$, milligrams per liter]

\begin{tabular}{|c|c|c|c|c|c|c|c|}
\hline Source of samples & $\begin{array}{c}\mathrm{DOC} \\
(\mathrm{mg} / \mathrm{L})\end{array}$ & $\begin{array}{l}\text { Hydrophobic } \\
\text { bases }\end{array}$ & $\begin{array}{l}\text { Hydrophobic } \\
\text { acids }\end{array}$ & $\begin{array}{l}\text { Hydrophobic } \\
\text { neutrals }\end{array}$ & $\begin{array}{l}\text { Hydrophilic } \\
\text { bases }\end{array}$ & $\begin{array}{l}\text { Hydrophilic } \\
\text { acids }\end{array}$ & $\begin{array}{l}\text { Hydrophilic } \\
\text { neutrals }\end{array}$ \\
\hline $\begin{array}{l}\text { White River Basin, Utah, surface water sampled } \\
\text { November } 1975 \text { (average of } 10 \text { samples). }\end{array}$ & 7.3 & 0.3 & 36.0 & 7.0 & 7.0 & 35.7 & 14.0 \\
\hline $\begin{array}{l}\text { White River Basin, Utah, surface water sampled } \\
\text { April } 1976 \text { (average of } 9 \text { samples). }\end{array}$ & 6.7 & 0 & 36.5 & 7.5 & 7.0 & 34.8 & 14.2 \\
\hline $\begin{array}{l}\text { Piceance Creek Basin, Colorado, surface water } \\
\text { sampled June } 1975 \text { (average of } 12 \text { samples) }{ }^{1} \text {. }\end{array}$ & 5.7 & 1.8 & 17.3 & 25.5 & 8.8 & 20.0 & 26.6 \\
\hline $\begin{array}{l}\text { Piceance Creek, Colorado, sampled } \\
\text { June } 1975 \text { (average of } 4 \text { samples) }{ }^{1} \text {. }\end{array}$ & 7.8 & 1.8 & 19.3 & 28.5 & 3.3 & 31.3 & 15.8 \\
\hline $\begin{array}{l}\text { White River sampled November } 1975 \text { near } \\
\text { Bonanza, Utah, and October } 1981 \text { near } \\
\text { Rangely, Colorado, (average of } 2 \text { samples). }\end{array}$ & 2.1 & .8 & 29.8 & 25.3 & 5.4 & 34.1 & 5.4 \\
\hline $\begin{array}{l}\text { Ground water from site-9 near Rock Springs, } \\
\text { Wyoming, sampled October } 1977 \text { (average of } \\
6 \text { samples). }\end{array}$ & 373 & 3 & 50 & 24 & 2 & 18 & 3 \\
\hline $\begin{array}{l}\text { Well D-8, tract C-a, Piceance Creek Basin, } \\
\text { Colorado, sampled October } 1981 \text {. }\end{array}$ & 2.3 & 6 & 26 & 15 & 20 & 24 & 9 \\
\hline $\begin{array}{l}\text { wells SG-6-1, SG-6-2, SG-6-3, SG-8R, SG-10R, } \\
\text { SG-20, tract C-b, Piceance Creek Basin, } \\
\text { Colorado (data from Slawson, 1980) }\end{array}$ & 3.3 & -- & 33.5 & 18.8 & 18.5 & \multicolumn{2}{|c|}{$\frac{\text { Total }}{29.2}$} \\
\hline
\end{tabular}

${ }^{1}$ Prelıminary nonstandard methodology (Leenheer and Huffman, 1976) was used, which resulted in shifts of dissolved-organic carbon from the hydrophobic-acid and hydrophilic-acid fractions into the hydrophobic-neutral fraction.

TABLE 16. - Variability of dissolved organic-carbon fractionations for 10 surface waters sampled in the White River Basin, Utah, November 1975

[DOC, dissolved-organic carbon]

\begin{tabular}{lccc}
\hline \multicolumn{1}{c}{ Fraction } & $\begin{array}{c}\text { Mean } \\
\text { (percent of DOC) }\end{array}$ & $\begin{array}{c}\text { Standard } \\
\text { deviation }\end{array}$ & $\begin{array}{c}\text { Coefficient of } \\
\text { variation }\end{array}$ \\
\hline Hydrophobic bases & 0.3 & 1 & 3.33 \\
Hydrophob1c ac1ds & 36.0 & 5 & .13 \\
Hydrophobic neut rals & 7.0 & 5 & .71 \\
Hydrophi1ic bases & 7.0 & 9 & 1.28 \\
Hydroph 11 1c acids & 35.7 & 16 & .44 \\
Hydrophilic neutrals & 14.0 & 11 & .78 \\
\hline
\end{tabular}

reducing as evidenced by hydrogen sulfide, are more homogeneous in solute chemistry, and their DOC concentration is much less (table 15). The wells listed in table 15 for the leased tracts in Colorado withdraw ground water that resides in the richest kerogen zones of Green River oil shale, and details of their construction are given in the report edited by Slawson (1980). Approximately onefifth of the DOC of the Colorado ground waters resides in the base fractions, which is an unusual aspect of these samples. The significant organic-nitrogen concentration of kerogen in the Green River Formation may be reflected in the large organic-base solute concentration in these ground waters. The larger DOC and organic-acid concen- trations in the Rock Springs ground waters most likely are related to oxidative weathering of kerogen of shallow oil shale, which cannot occur in the deeper oil-shale strata being developed at the leased tracts in Colorado.

\section{ISOLATION AND FRACTIONATION OF NATURAL ORGANIC SOLUTES FROM WATER}

To obtain more specific structural information than analytical DOC-fractionation data about natural organic solutes in water, the preparative DOC-fractionation procedure (Leenheer, 1981) was scaled up and modified to produce gram quantities of natural organic-solute fractions from processing a few hundred liters of water (Leenheer and Noyes, 1985). These large organic-solute fractions then were characterized by elemental analysis, functional-group analysis, infrared spectroscopy, and proton nuclear magnetic resonance spectroscopy to obtain organic structural information.

A modular filtration and column-adsorbent system was constructed for onsite concentration and fractionation of organic solutes from large volumes of water. This system was housed in a mobile laboratory, and flow of water to and from the mobile laboratory is shown in figure 29. Flow of water through the filtration and columnadsorbent system within the mobile laboratory is shown in figure 30 . An average of 1 to $2 \mathrm{~L} / \mathrm{min}$ of water was processed through this system, and a fortyfold to fiftyfold 
concentration factor of organic solutes in water was attained at the field sampling site. Additional concentration by vacuum rotary evaporation, desalting, and freezedrying was done in the laboratory after sampling. Specific details on the operation of the filtration and column adsorbent system and on the final processing of the organicsolute fractions is given by Leenheer and Noyes (1985).

\section{ORGANIC-SOLUTE CHARACTERIZATION OF GROUND WATER AT THE RIO BLANCO SITE, PICEANCE CREEK BASIN, COLORADO}

A preliminary run of well D-8 ground water through the preparative DOC-fractionation procedure revealed that large quantities of sulfur were being isolated with the hydrophobic-acid fraction as evidenced by sulfur fouling of the XAD- 8 resin. Subsequent tests on this sulfur revealed that most of this sulfur was speciated as polysulfide anion. Polysulfide imparted a yellowish-green color to well D-8 ground water, and it slowly decomposed to elemental sulfur and hydrogen sulfide when the water samples, columns, and fraction concentrations were acidified. Because the elemental sulfur that was produced fouled the adsorbent resin columns, a method was sought to eliminate polysulfide and hydrogen sulfide from the water before it was processed. The addition of $40 \mathrm{mg} / \mathrm{L}$ of zinc as zinc sulfate was found to quantitatively remove polysulfide and sulfide from solution after 1 hour of precipitate formation. Gravimetric determination of the precipitate found $24.5 \mathrm{mg} / \mathrm{L}$ sulfur as sulfide. About 10 percent of the dissolved organic carbon coprecipitated with the zinc sulfide, and no satisfactory method was found to recover this carbon from the precipitate.

On December 2, 1981, $304 \mathrm{~L}$ of well D-8 water was processed through the filtration and column-adsorbent system after zinc-sulfide precipitation. A total of $786 \mathrm{mg}$ of organic carbon was recovered (89-percent recovery of DOC), which was fractionated as follows: $13 \mathrm{mg} \mathrm{C}$ (carbon) as hydrophobic bases, $12 \mathrm{mg} \mathrm{C}$ as weak hydrophobic acids, $19 \mathrm{mg} \mathrm{C}$ as hydrophilic bases, and $742 \mathrm{mg} \mathrm{C}$ as strong hydrophobic and hydrophilic acids. The strong hydrophobic- and hydrophilic-acid fractions were not separated because the column capacity-factor $\left(k^{\prime}\right)$ cutoff was kept as low as 2 during the laboratory desalting of this fraction on a column of XAD-8 resin.

The hydrophobic- and hydrophilic-base fractions were assayed for pyridines, quinolines, and hydroxypyridines by liquid-chromatographic procedures used for the analyses of oil-shale retort wastewaters (Leenheer and others, 1982). No aromatic amines were found. Only broad, undefined peaks characteristic of natural organic polymeric material were obtained.
Elemental analyses of certain organic-solute fractions from well D-8 ground water are shown in table 17 . A complete elemental analysis was possible only on the strong hydrophobic- and hydrophilic-acids fraction, because insufficient material was obtained in the other fractions isolated. The hydrophilic-base fraction had a significant nitrogen concentration, and its minimal carbon concentration indicated that much of the material isolated in this fraction was inorganic in nature. The combined acids fraction also contained a relatively large nitrogen concentration (2.6 percent) compared to most aquatic organic acids whose nitrogen concentration is near 1 percent (E. M. Thurman and R. L. Malcolm, U.S. Geological Survey, written commun., 1982). The large nitrogen concentration in these fractions is reflective of kerogen in the Green River Formation. The nitrogen concentration of kerogen averages 2.2 percent (Saxby, 1959).

The acids fraction had a much greater oxygen concentration ( 33 percent versus 6.0 percent) and smaller hydrogen ( 5.4 percent versus 10.3 percent) and carbon ( 49.7 percent versus 80.5 percent) concentrations than kerogen in the Green River Formation. The large oxygen and nitrogen concentrations and smaller carbon and hydrogen concentrations in organic solutes in ground water in the Green River Formation compared to kerogen in the Green River Formation, probably represent water-solubility partitioning of polar oxygen- and nitrogen-containing constituents of kerogen into ground water. Apparently, a very small percentage of kerogen is soluble in ground water at well $\mathrm{D}-8$ because the DOC concentration is only $2.3 \mathrm{mg} / \mathrm{L}$.

Carbon and sulfur analysis of the zinc-sulfide precipitate indicated that the precipitate was not pure zinc sulfide. Dissolution of the precipitate in nitric acid followed by plasma atomic-emission spectroscopic analysis found certain heavy metals $(\mathrm{Cr}, \mathrm{Co}$, and $\mathrm{Mo}$ ) that are characteristic of, and may be derived from, stainless steel corrosion products in the well-pump system at well $\mathrm{D}-8$. The carbon concentration in the precipitate is indicative of coprecipitated organic solutes discussed previously.

The fraction characterized in greatest detail was the strong hydrophobic- and hydrophilic-acids fraction that comprised 94 percent of the isolated material. These acids were almost pure white in color after freeze-drying. An aqueous titration of this acid fraction with sodium hydroxide found $5.5 \mathrm{meq} / \mathrm{g}$ of acid that was taken as a measure of free carboxyl groups. The remaining characterizations were made by combining chemical derivatizations with infrared and nuclear magnetic resonance spectroscopic characterizations.

The infrared spectrum of the underivatized acid fraction of well D-8 is shown in figure 31 . This spectrum is distinguished by two features: (1) The strong carboxyland carbonyl-group absorbance at $1,720 \mathrm{~cm}^{-1}$ (reciprocal centimeters), which is indicative of its acid concentration; 


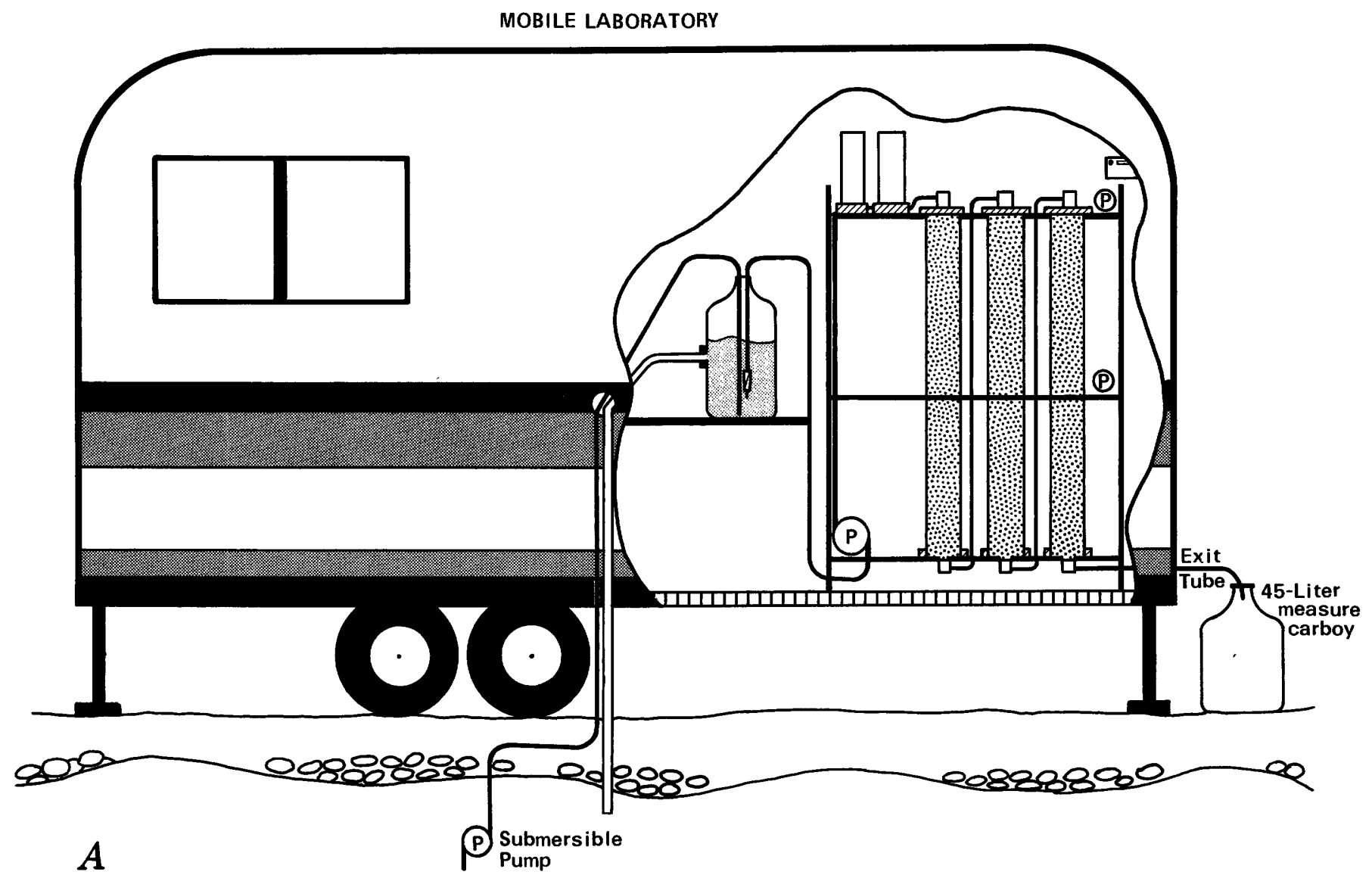

FigurE 29. - Flow of water through mobile laboratory (from Leenheer and Noyes, 1985).

and (2) the silica bands at $1,080,950$, and $800 \mathrm{~cm}^{-1}$. This silica most likely is silicic acid esterified to organic acids and alcohols and probably is the major component of the 5.86-percent ash concentration shown by data in table 17 . There was no indication of any aromatic character of these organic acids.

Proton nuclear magnetic resonance (NMR) spectra of the well D-8 acids were run in deuterium oxide and deuterated dimethylsulfoxide solvents. A trace amount of trifluoroacetic acid was added to the dimethylsulfoxide to shift the adsorbed water peak from the spectral region of interest. The two NMR spectra were combined, the solvent peaks were subtracted, and the composite NMR spectrum is shown in figure 32 . Integration of the proton NMR spectrum results in the quantitative assignment of hydrogen to the following structures: aliphatic-methyl and methylene hydrogen $(0$ to $1.75 \mathrm{ppm})=61.5$ percent of total integral; aliphatic hydrogen on carbons alpha to carboxyl and carbonyl groups ( 1.75 to $3.0 \mathrm{ppm})=29.7$ percent; aliphatic hydrogens on carbons attached to ester, ether, and hydroxyl oxygens $(3.0$ to $5.0 \mathrm{ppm})=$ 7.1 percent; and aromatic hydrogens $(7.0$ to $8.5 \mathrm{ppm})=$ 1.7 percent.
TABLE 17.-Elemental analyses of organic-solute fractions from Rio Blanco well D-8, tract C-a, Piceance Creek Basin, Colorado

\begin{tabular}{|c|c|c|c|}
\hline Elements & $\begin{array}{l}\text { Hydrophilic } \\
\text { bases } \\
\text { (percent) }\end{array}$ & $\begin{array}{l}\text { Strong hydrophobic } \\
\text { and hydrophilic acids } \\
\text { (percent) }\end{array}$ & $\begin{array}{c}\text { Zinc sulfide } \\
\text { and polysulfide } \\
\text { precipitate } \\
\text { (percent) }\end{array}$ \\
\hline Carbon & 18.22 & 49.67 & 0.89 \\
\hline Hydrogen & 5.21 & 5.4 & $\cdots$ \\
\hline Oxygen & --- & 33.0 & $-\cdots$ \\
\hline Nitrogen & 13.44 & 2.43 & $\cdots$ \\
\hline Sulfur & -.- & 1.97 & 23.88 \\
\hline Ash & $\ldots$ & 5.86 & --- \\
\hline
\end{tabular}

Quantitative information on carbonyl concentration in well D-8 organic acids was obtained by synthesizing the methoxime and measuring the increase in hydrogen concentration by proton NMR as determined by the methoxy peak at 3.5 to $3.8 \mathrm{ppm}$. The methoxime was synthesized by heating the sample in $0.1 N$ (normal) methoxime acetate at $85^{\circ} \mathrm{C}$ for 1 hour, passing the sam- 


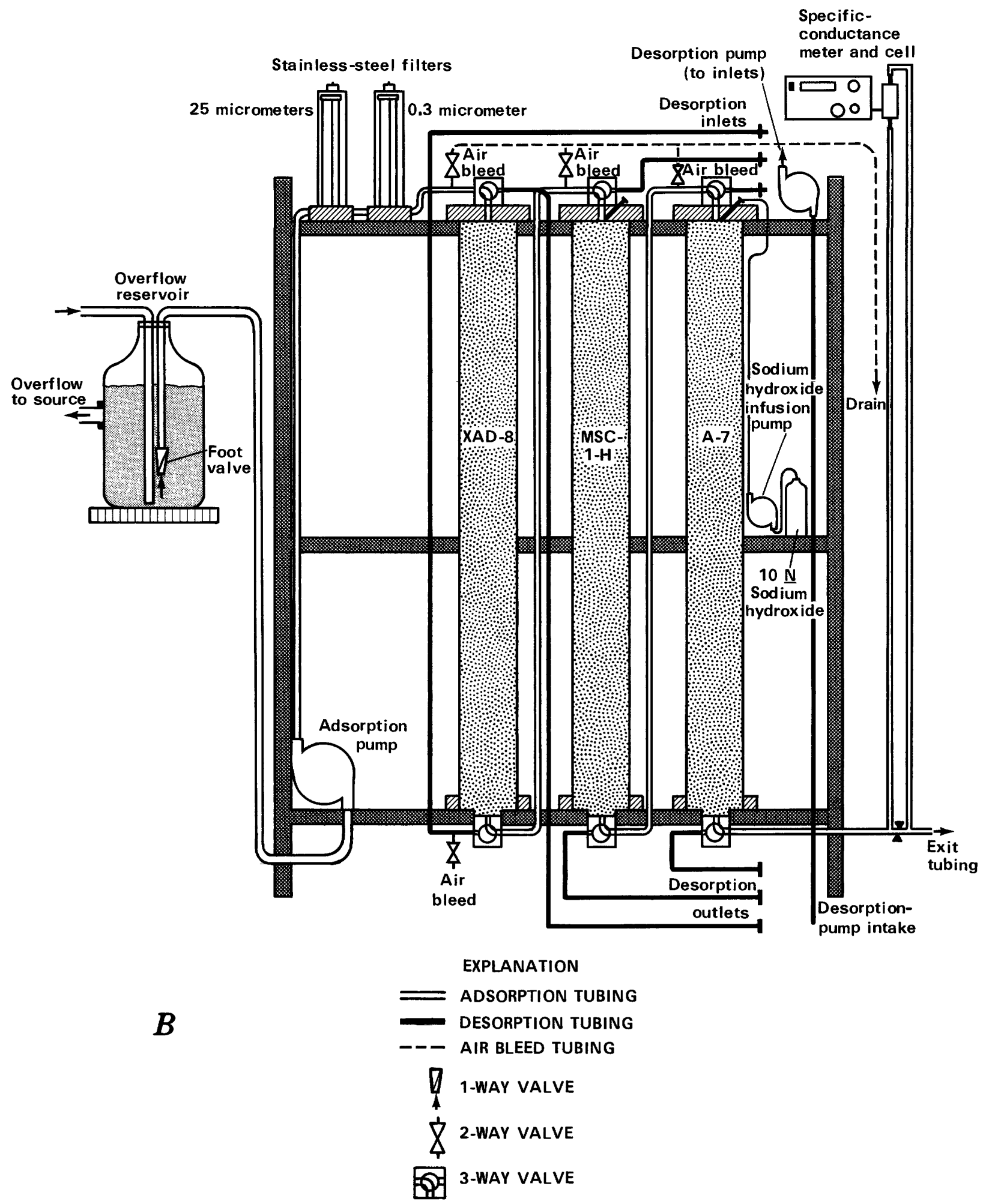

FiguRE 30.-Flow of water through filtration and column-adsorbent system (from Leenheer and Noyes, 1985).

ple through a hydrogen-saturated cation-exchange resin to remove unreacted methoxime cations and freeze-drying the sample to remove water and acetic acid.
Lastly, aliphatic-hydroxyl groups were determined by forming the trifluoroethyl ethers by reacting the sample suspended in methylene chloride with trifluorodiazoethane 


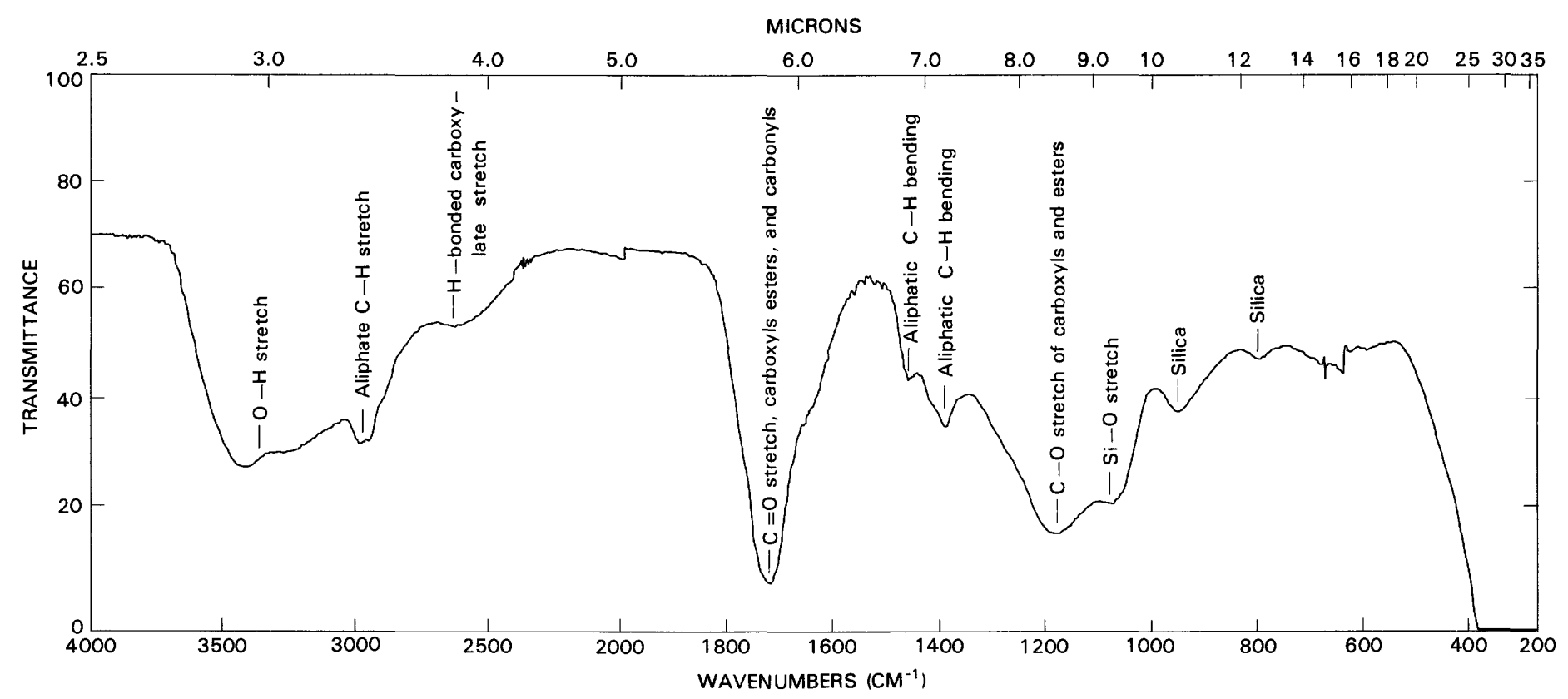

FIGURE 31. - Infrared spectrum of organic acids of ground water in well D-8.

(Koller and Dorn, 1982). Aliphatic-alcohol ether derivatives can be resolved from carboxylic-acid ester derivatives by F-19 (fluorine-19) NMR. When the F-19 NMR spectrum was run on the derivatized well D-8 organic acids, only trifluoroethyl ester derivatives were detected, and therefore, aliphatic-hydroxyl concentration, if present, must be minimal.

A summary of all qualitative organic structural and functional-group information is given in table 18 . The following conclusions can be reached about well D-8 organic acids, which closely conform to the Yen-YoungShih structure model of kerogen in the Green River Formation (Yen, 1976):

1. Aromatic-carbon systems are present only in minute quantities; however, this does not rule out the presence of isolated double bonds such as those present in substituted hydroaromatic or heterocyclic systems.

2 . The bulk of the carbon skeleton consists of aliphatic-naphthenic rings. Five- and six-membered rings predominate.

3. Free-end and flexible long-chain linear polymethylene structures are absent, as evidenced by the absence of terminal methyl groups in the proton NMR spectrum.

4. Aliphatic-naphthenic ring clusters most likely are predominately linked with ether bridges and to a lesser extent, linked with ester bridges. Significant quantities of oxyen are not associated with hydrocarbon structures; therefore, these bridges are at Tertiary or Quaternary carbon sites.

The major difference between the well D-8 organic acids and the Yen-Young-Shih model of kerogen is the significant carboxyl concentration in well D-8 acids. The water solubility of these acids undoubtedly is due to its polar carboxylate concentration. There is slightly more than one carboxyl group on each naphthenic ring.

The close correspondence of well D-8 organic acids to the structure of kerogen in the Green River Formation provides a valuable indicator to distinguish these solutes from organic contaminants and organic solutes of natural origin in surface waters. The proton NMR spectrum, in particular, is the best tool for assaying the unique characteristics of organic solutes derived from oil shale of the Green River Formation.

\section{ORGANIC-SOLUTE ASSESSMENT OF THE WHITE RIVER}

In addition to the analytical DOC-fractionation data discussed previously in connection with table 13, two large-volume samples from the White River were processed through the preparative DOC-fractionation procedure to obtain sufficient material for extensive chemical characterization (Leenheer and Noyes, 1985). The sampling site was $25.4 \mathrm{~km}$ east of Rangely, Colorado, on State Highway 64 at a Rio Blanco County road bridge that crosses the White River. The first sampling was during a low-flow period from September 21 to 25, 1981. The second sampling was during the peak of the spring runoff from June 7 to 11,1982 . The sampling site was downstream from all surface-water inputs to the White River from the Piceance Creek Basin and upstream from the city of Rangely. The volume of water processed and 


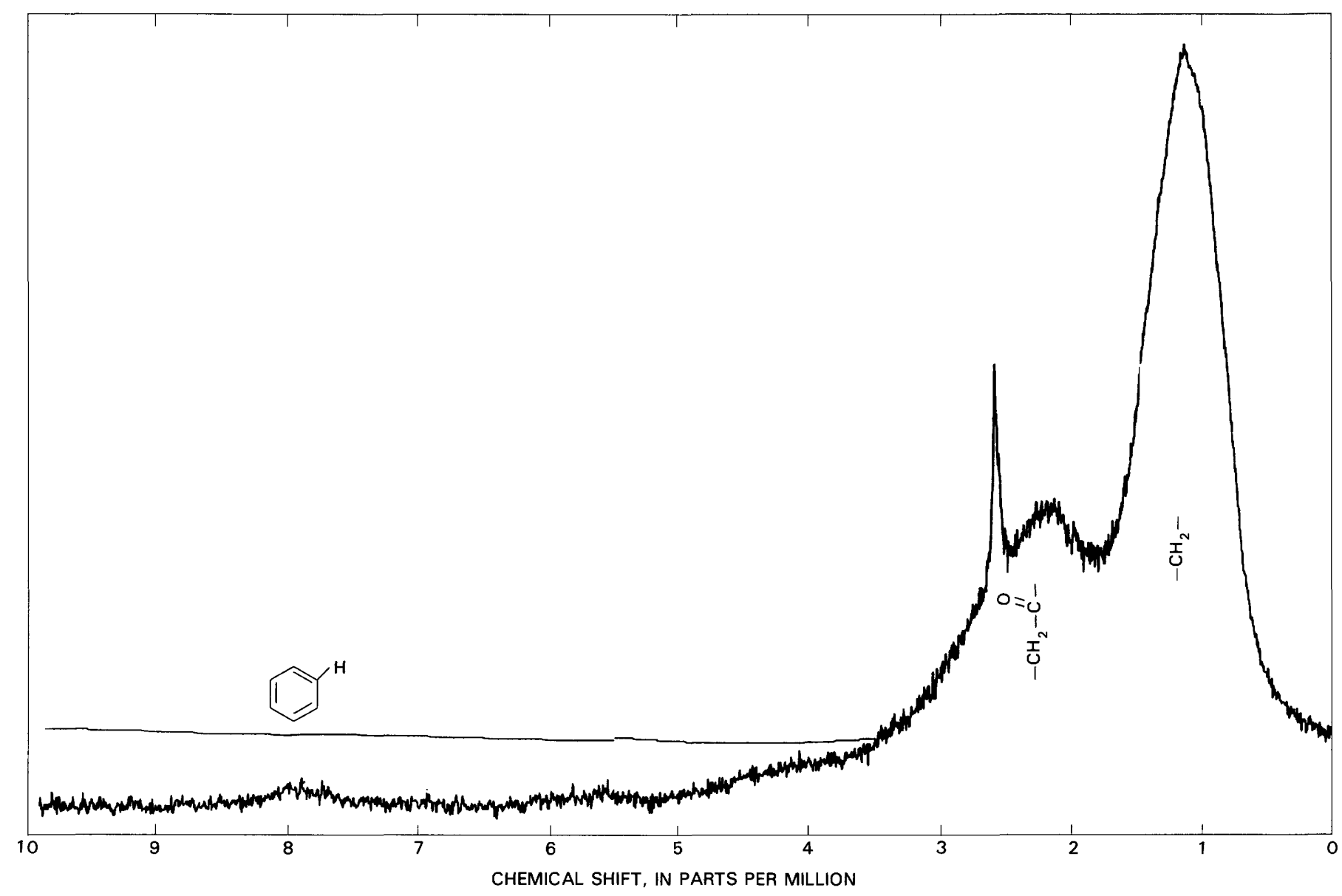

FIGURE 32.- Proton nuclear magnetic resonance (NMR) spectrum of organic acids of ground water in well D-8.

quantity of organic solutes recovered in the various fractions are summarized in table 19.

Organic-carbon recoveries are underestimated in table 19 because hydrophobic- and hydrophilic-neutral fractions (estimated to be about 30 percent of the carbon from the White River, based on data from table 15) were not recovered in the preparative fractionation. Therefore, the September 1981 sample gave about the correct recovery (64 percent) for the remaining four fractions, but the June 1972 sample gave an overestimated recovery (154 percent). Variations in DOC concentration with time are the most probable reasons for the significant carbon recovery of the June sample, because only one sample for DOC determination was taken during the 4-day sampling period.

The September 1981 sample was subjected to one of the first organic structural studies ever undertaken of both humic and non-humic substances of natural origin in a surface water. Therefore, much of this sampling was devoted to developing and applying characterization methods for these organic-solute fractions.

About 94 percent of the recovered carbon resided in the strong hydrophobic- and hydrophilic-acid fractions in the September 1981 sample. To obtain more specific information on the various acid groups within this mixture, this acid fraction was subdivided further by the following procedures. The entire solute fraction was concentrated about tenfold by vacuum rotary evaporation. A precipitate formed that was designated humic-acid no. 1 . After separating this percipitate by centrifugation, the concentrate was acidified to $\mathrm{pH} 2$, and a second precipitate formed that was designated humic-acid no. 2 . The acidified concentrate was passed through a XAD- 8 column so that all acids with capacity factors $\left(k^{\prime}\right)$ greater than ten were retained. After desorption, this acid fraction was designated strong hydrophobic acids. The column effluent containing hydrophilic acids was passed through two successive XAD- 8 columns to isolate a hydrophilic-acid no. 1 fraction whose $k^{\prime}$ for XAD-8 ranged from 2 to 10 and a hydrophilic-acid no.2 fraction whose $k^{\prime}$ for XAD-8 ranged from 0.3 to 2.0. Acids whose $k^{\prime}$ for XAD-8 was less than 0.3 were called ultrahydrophilic acids, and they were isolated from inorganic salts by a series of recrystallation, precipitation, and evaporation 
TABLE 18.-Quantitative organic structural- and functional-group information on well D-8 organic acids

[NMR, nuclear magnetic resonance]

\begin{tabular}{|c|c|c|c|}
\hline $\begin{array}{l}\text { Structurd - ar } \\
\text { functiond }- \\
\text { group unit }\end{array}$ & $\begin{array}{l}\text { Quantitative } \\
\text { result }\end{array}$ & $\begin{array}{c}\text { Data } \\
\text { source }\end{array}$ & Assumptions \\
\hline Empirical formula. & $\mathrm{C}_{67} \mathrm{H}_{88} \mathrm{O}_{34} \mathrm{~N}_{3} \mathrm{~S}$ & Elemental dnalysis. & None. \\
\hline \multicolumn{4}{|l|}{ Hydrogen (H) distribution } \\
\hline Acidic-carboxyl hydrogen. & $8-\mathrm{H}$ & Titration data. & $\begin{array}{l}\text { All acidic } \mathrm{H} \text { are } \\
\text { carboxyl } \mathrm{H} \text {. }\end{array}$ \\
\hline $\begin{array}{l}\text { Isolated alıphatic-hydrocarbon } \\
\text { hydrogen. }\end{array}$ & 49-H & Proton NMR. & $\begin{array}{l}\text { No other hydrogen } \\
\text { types in assigned } \\
\text { NMR peak. }\end{array}$ \\
\hline $\begin{array}{l}\text { Al 1phatic hydrogen on carbons } \\
\text { alpha to carbonyl, carboxyl, } \\
\text { and ester groups. }\end{array}$ & $24-\mathrm{H}$ & Proton NMR. & Do. \\
\hline $\begin{array}{l}\text { Alıphat } 1 \mathrm{c} \text { hydrogen on carbons } \\
\text { attached to hydroxyl ester and } \\
\text { ether oxygens. }\end{array}$ & $6-\mathrm{H}$ & Proton NMR. & Do. \\
\hline Aromatıc hydrogen. & $1-\mathrm{H}$ & Proton NMR. & Do. \\
\hline \multicolumn{4}{|l|}{ oxygen (0) distribution } \\
\hline Carboxyl oxygen. & $17-0$ & Titration data. & $\begin{array}{l}\text { All acidic } \mathrm{H} \text { are } \\
\text { carboxyl } \mathrm{H} \text {. }\end{array}$ \\
\hline \multicolumn{4}{|l|}{ oxygen (o) distribution } \\
\hline Carbonyl oxygen. & $3-0$ & $\begin{array}{l}\text { Methoxıme derıvative, } \\
\text { proton NMR. }\end{array}$ & $\begin{array}{l}\text { Quantitative } \\
\text { derivatization. }\end{array}$ \\
\hline Ester oxygen. & $3-0$ & Proton NMR. & $\begin{array}{l}\text { One-half of } 6-\mathrm{H} \\
\text { associated with } \\
\text { esters and ethers } \\
\text { are esters, and } \\
\text { hydrogens are } \\
\text { methylene- } \mathrm{H} \text {. }\end{array}$ \\
\hline Silica oxygen. & 4-0 & $\begin{array}{l}\text { Infrared spectrum, } \\
\text { ash concentration. }\end{array}$ & $\begin{array}{l}\text { Ash is } 100 \text { percent } \\
\text { silica. }\end{array}$ \\
\hline Aliphatic-hydroxyl oxygen. & Not detected. & $\begin{array}{l}\text { Derivatization, } \\
\text { fluorine NMR. }\end{array}$ & $\begin{array}{l}\text { Quantıtative } \\
\text { derıvatization. }\end{array}$ \\
\hline Ether oxygen. & 7-0 & $\begin{array}{l}\text { Difference from total } \\
\text { oxygen. }\end{array}$ & $\begin{array}{l}\text { Ali residual oxygens } \\
\text { are ether oxygen. }\end{array}$ \\
\hline N1trogen concentration. & $\begin{array}{l}\text { 3-nonbasic } \\
\text { nitrogen. }\end{array}$ & Elemental analysis. & $\begin{array}{l}\text { Basic nitrogen would } \\
\text { not be present in } \\
\text { acids. }\end{array}$ \\
\hline Sulfur concentration. & $1-S$ & Elemental analysis. & None. \\
\hline Number of rings or double bonds & 24 & $\begin{array}{l}\text { Calculated from } \mathrm{C}: \mathrm{H} \\
\text { ratio of empirical } \\
\text { formula. }\end{array}$ & None. \\
\hline Carboxyi oxygen double bonds. & 8 & Titration data. & $\begin{array}{c}\text { All acidic hydrogen } \\
\text { are carboxyl } \mathrm{H} \text {. }\end{array}$ \\
\hline Carbonyl oxygen double bonds. & 3 & $\begin{array}{l}\text { Methoxime derivative, } \\
\text { proton, NMR. }\end{array}$ & $\begin{array}{l}\text { Quantitative } \\
\text { derivative } \\
\text { formation. }\end{array}$ \\
\hline Ester oxygen double bonds. & 2 & Proton NMR. & Same as ester oxygen. \\
\hline $\begin{array}{c}\text { Aromatic rings and double bonds } \\
\text { associated with aromatic } H \text {. }\end{array}$ & 3 & Proton NMR. & $\begin{array}{l}33 \text { percent of rings } \\
\text { are substituted with } \\
\text { aromatic hydrogen. }\end{array}$ \\
\hline Unaccounted rings and double bonds. & 7 & $\begin{array}{l}\text { Difference from total } \\
\text { rings and double } \\
\text { bonds. }\end{array}$ & All of above. \\
\hline $\begin{array}{l}\text { Ratio of unaccounted rings and } \\
\text { doubie bonds with structural } \\
\text { carbon (excluding carboxyl carbon) }\end{array}$ & $\begin{array}{l}1 \text { ring or } \\
\text { double bond } \\
\text { per } 9.7 \text { carb }\end{array}$ & $\begin{array}{l}\text { All of above. } \\
\text { ons. }\end{array}$ & Do. \\
\hline
\end{tabular}


TABLE 19. - Organic-carbon recoveries from the White River using filtration and column-adsorbent system [mg/L, milligrams per liter: L, liters; mg C, milligrams of carbon]

\begin{tabular}{|c|c|c|}
\hline \multirow{2}{*}{ Sample } & \multicolumn{2}{|c|}{ Date of sample } \\
\hline & September $21-25,1981$ & June $7-11,1982$ \\
\hline Dissolved organic carbon (mg/L) & 2.3 & 2.7 \\
\hline Water volume processed (L) & 1,091 & 725 \\
\hline Hydrophobic bases (nig C) & 1.5 & -- \\
\hline Hydroph ${ }_{11} 1 \mathrm{c}$ bases (mg C) & 46 & 258 \\
\hline Weak hydrophobic acids (mg C) & 51 & 188 \\
\hline $\begin{array}{l}\text { Strong hydrophobic and hydrophilic } \\
\text { acids (mg C) }\end{array}$ & 1,498 & 2,563 \\
\hline $\begin{array}{l}\text { Est } 1 \text { mated organic-carbon recovery } \\
\text { (percent) }\end{array}$ & 64 & 154 \\
\hline
\end{tabular}

steps (Leenheer and Noyes, 1985). The material balance for these subfractionation steps of the acid fractions is shown in table 20.

The two humic-acid fractions were treated with a mixture of hydrochloric and hydrofluoric acids (HCL-HF) to remove silica (Leenheer and Moe, 1969), which was a major component of these fractions. Fifty-eight percent of humic-acid no. 1 and 50 percent of humic-acid no. 2 were converted into fulvic acid by the HCL-HF treatment indicating that silica is instrumental in converting fulvic acid to humic acid.

The distribution of acids as $k^{\prime}$ for XAD-8 increased was bimodal in nature, with the majority of material found at $k^{\prime}>10$ and $k^{\prime}<0.3$. This may indicate two sources
TABLE 20.-Subfractionation of strong hydrophobic- and hydrophilic-acid fractions from the White River, sampled September 1981

\begin{tabular}{|c|c|c|}
\hline Fraction & $\begin{array}{l}\text { Milligrams } \\
\text { of carbon }\end{array}$ & $\begin{array}{l}\text { Percent } \\
\text { of total }\end{array}$ \\
\hline Strong hydrophobic and hydrophilic acıds & 1,498 & 100 \\
\hline Humic-acid no. 1 & 122 & 8.1 \\
\hline Humic-acid no. 2 & 115 & 7.7 \\
\hline Strong hydrophobic acids $\left(k^{\prime}>10\right)$ & 621 & 41.5 \\
\hline Hydrophulic-aceds no. $1\left(k^{-1}=2-10\right)$ & 240 & 16.0 \\
\hline Hydrophatic-atids no. $2\left(k^{\prime}=0.3-2\right)$ & 78 & 5.2 \\
\hline Ulerahydrophllic at $1 \mathrm{ds}\left(k^{\prime}, 0.3\right)$ & 272 & 18.2 \\
\hline Carbon losses during fractionation & 49 & 3.3 \\
\hline
\end{tabular}

and (or) processes that lead to this bimodal distribution of material.

Various wet-chemical tests were performed on the fractions to better elucidate components in these mixtures. The acids were titrated with standard sodium hydroxide. The titer of the acids up to $\mathrm{pH} 8$ was strong acids and the titer from $(\mathrm{pH} 8-10 \times 2)$ was defined as weak acids (E. M. Thurman and R. L. Malcolm, U.S. Geological Survey, written commun., 1982). Total polysaccharides were determined by the colorimetric phenol-sulfuric acid test (Kedeti and Lederer, 1974) and uronic acids were determined by the colorimetric carbazole test (Kedeti and Lederer, 1974). Results for these analysis are shown in table 21 .

Two end-member types of organic solutes are indicated by the data in table 19 . The first type represents a humified solute probably resulting from a decay sequence

TABLE 21.-Chemical analyses of organic-solute fractions from the White River, sampled September 1981

\begin{tabular}{|c|c|c|c|c|}
\hline $\begin{array}{r}\text { Str } \\
\text { (mill } \\
\text { per }\end{array}$ & $\begin{array}{l}\text { long acids } \\
\text { iequivalents } \\
\text { gram carbon) }\end{array}$ & $\begin{array}{l}\text { weak acıds } \\
\text { (milliequivalents } \\
\text { per gram carbon) }\end{array}$ & $\begin{array}{l}\text { Polysaccharides } \\
\text { (percent of } \\
\text { fractıon carbon) }\end{array}$ & $\begin{array}{l}\text { Uronic acids } \\
\text { (percent of } \\
\text { fraction carbon) }\end{array}$ \\
\hline Humic-acid no. $1^{1}$ & 9.48 & 2.72 & 2.9 & 1.0 \\
\hline Humic-acid no. $2^{1}$ & 5.55 & 2.22 & 18.1 & 3.6 \\
\hline Strong hydrophobic acids $\left(k^{\prime}>10\right)$ & 12.70 & 1.38 & 1.9 & .3 \\
\hline Hydrophilic-acids no. $1\left(k^{\prime}=2-10\right)$ & 15.63 & 1.78 & 4.5 & .5 \\
\hline Hydroph1lic-acids no. $2\left(k^{\prime}=0.3-2\right)$ & 6.24 & 1.10 & 7.1 & .3 \\
\hline Ultrahydroph $11 \mathrm{c}$ acids $\left(k^{\prime}<0.3\right)$ & $\cdots$ & $\cdots$ & 26.9 & 2.4 \\
\hline Hydrophilic bases & --- & +- & 16.0 & .9 \\
\hline
\end{tabular}

\footnotetext{
${ }^{1} \mathrm{~S}$ lica removed by $\mathrm{HCl}-\mathrm{HF}$.
} 
TABLE 22. - Elemental analyses of organic-solute fractions isolated from the White River, sampled September 1981

\begin{tabular}{|c|c|c|c|c|c|}
\hline $\begin{array}{r}\text { Humıc- } \\
(\mathrm{p}\end{array}$ & $\begin{array}{l}\text { c-acid no. } 1^{1} \\
\text { (percent) }\end{array}$ & $\begin{array}{l}\text { Humic-acid no. } 2^{2} \\
\text { (percent) }\end{array}$ & $\begin{array}{c}\text { Strong hydrophobic acıds } \\
\qquad k^{\prime}>10 \\
\text { (percent) }\end{array}$ & $\begin{array}{l}\text { Hydrophilic acids } \\
\qquad k^{\prime}=2-10 \\
\text { (percent) }\end{array}$ & $\begin{array}{l}\text { Hydrophilic } \\
\text { bases } \\
\text { (percent) }\end{array}$ \\
\hline Carbon & 45.09 & 40.68 & 50.35 & 42.85 & 29.65 \\
\hline Hydrogen & 4.26 & 5.15 & 5.08 & 4.41 & 4.85 \\
\hline Oxygen & 26.7 & 22.44 & 41.36 & 40.2 & 26.0 \\
\hline N1trogen & 4.06 & 5.31 & 1.73 & 2.78 & 7.85 \\
\hline Sulfur & --- & -- & 1.08 & 1.54 & 2.83 \\
\hline Ash & 9.95 & 16.71 & 1.37 & 6.52 & 28.53 \\
\hline Empirical formula & $\mathrm{C}_{13} \mathrm{H}_{15} \mathrm{O}_{6} \mathrm{~N}$ & $\mathrm{C}_{9} \mathrm{H}_{14} \mathrm{O}_{4} \mathrm{~N}$ & $\mathrm{C}_{125} \mathrm{H}_{151} \mathrm{O}_{77} \mathrm{~N}_{4} \mathrm{~S}_{1}$ & $\mathrm{C}_{74} \mathrm{H}_{92} \mathrm{O}_{52} \mathrm{~N}_{4} \mathrm{~S}_{1}$ & $\mathrm{C}_{28} \mathrm{H}_{55} \mathrm{O}_{18} \mathrm{~N}_{6} \mathrm{~S}$ \\
\hline $\begin{array}{l}\text { Index of hydrogen deficiency/ } \\
\text { number carbons. }\end{array}$ & 0.50 & 0.33 & 0.40 & 0.39 & 0.16 \\
\hline $\begin{array}{l}\text { Index of hydrogen deficiency per } \\
\text { number of carbons after sub- } \\
\text { tracting carboxyl-group (stron } \\
\text { acidity) double bonds. }\end{array}$ & er .39 & .27 & .25 & .20 & -.- \\
\hline
\end{tabular}

that is high in strong-acid acidity and low in carbohydrate and uronic-acid concentrations. These humified materials are represented by the strong hydrophobicacid and hydrophilic-acid no. 1 fractions. The second type of material probably represents undecomposed or partly decomposed material of biological origin, which is low in acidity and high in polysaccharide and uronic-acid concentration. This material is represented by hydrophilicacid no. 2, ultrahydrophilic acids, hydrophilic bases, and humic-acid no. 2. The ultra hydrophilic-acid fraction has the largest polysaccharide concentration ( 26.9 percent of fraction carbon), which undoubtedly results in the very hydrophilic character of this fraction. The humic-acid no. 2 fraction has the greatest uronic-acid concentration, because plant hemicelluloses high in uronic acids partition into this fraction (Robinson, 1980).

Elemental analyses of organic-solute fractions isolated from the White River in the September 1981 sample are shown in table 22 . The most significant information derived from data in table 22 is the ratio of the index of hydrogen deficiency (number of rings and double bonds) to the number of carbons in the empirical formula. This ratio gives an estimate of the degree of unsaturation of the mixture of molecules in each fraction. The hydrophilicbase fraction is saturated almost completely with hydrogen. The strong hydrophobic- and hydrophilic-acid fractions are moderately unsaturated, but approximately one-half of this unsaturation can be accounted for by carboxylate concentration as estimated by the strong-acid acidity shown in the data in table 22 . The humic-acid no. 2 fraction gives about the same degree of unsaturation as the strong hydrophobic- and hydrophilic-acid fractions after factoring in the carboxylate concentration, but the humic-acid no. 2 fraction has a much greater degree of unsaturation than the remaining fractions. Part of this unsaturation is due to conjugated rings and double bonds that produce color, and this solute fraction has a much darker color than the remaining fractions. The elemental data in table 22 also show that nitrogen, sulfur, and ash concentrations tend to increase as the fractions become more hydrophilic. The nitrogen and sulfur heteroatoms and the ash representing inorganic constituents all may be integral organic structural components of these fractions. The isolation procedures were developed and tested to discriminate against inorganic solutes (Leenheer and Noyes, 1985).

Qualitative information that substantiated the chemical analytical data was provided by infrared spectroscopy. Infrared spectra of the two humic-acid fractions are shown in figure 33 , and the spectra of the strong hydrophobicand hydrophilic-acid fractions are shown in figure 34 . The aromatic character of humic-acid no. 1 is shown by bands at 1,630 and $1,500 \mathrm{~cm}^{-1}$, whereas the hydroxylic character resulting from polysaccharide components of 


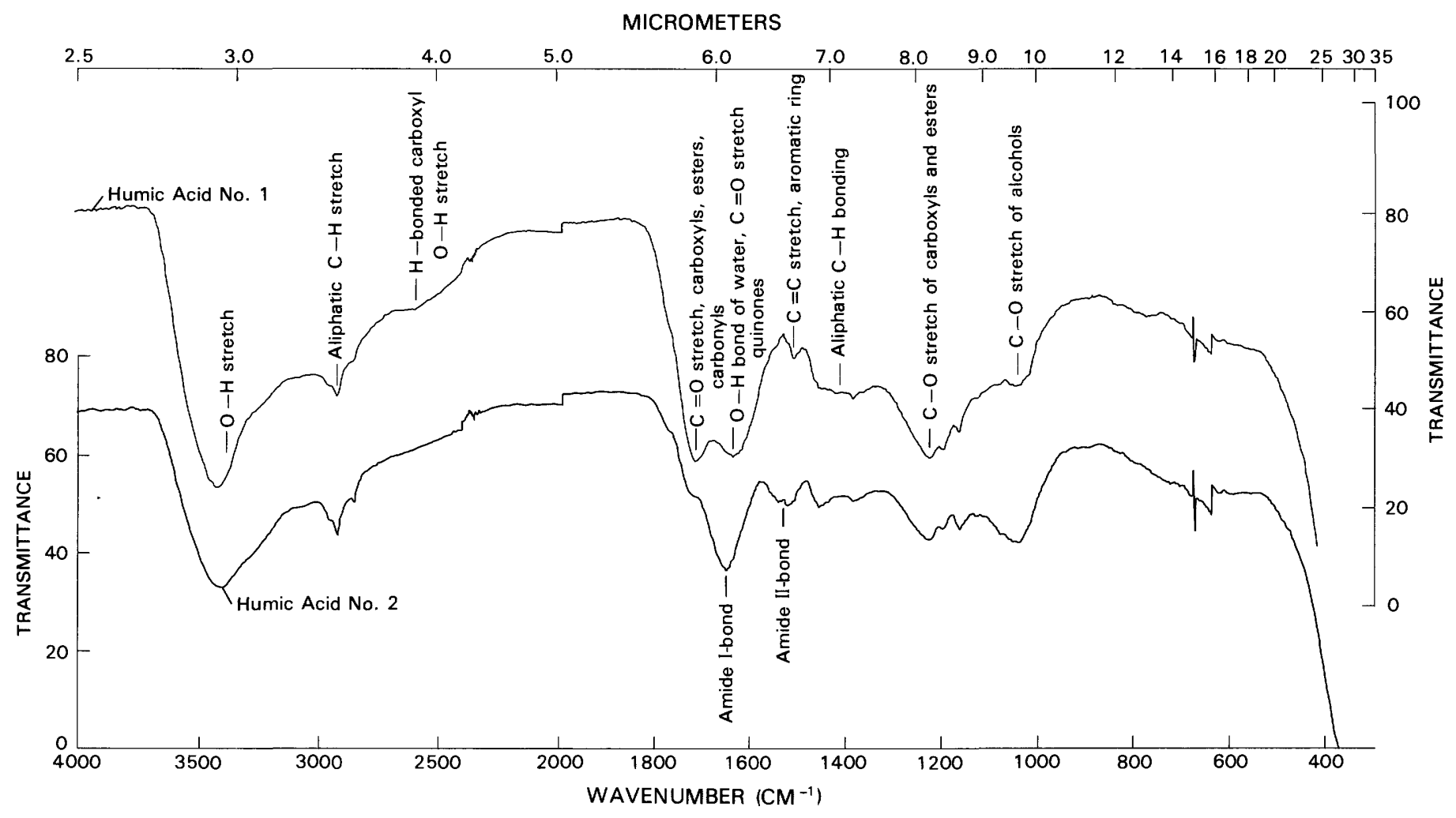

FIGURE 33.-Infrared spectra of humic acids of the White River; river sampled September 1981.

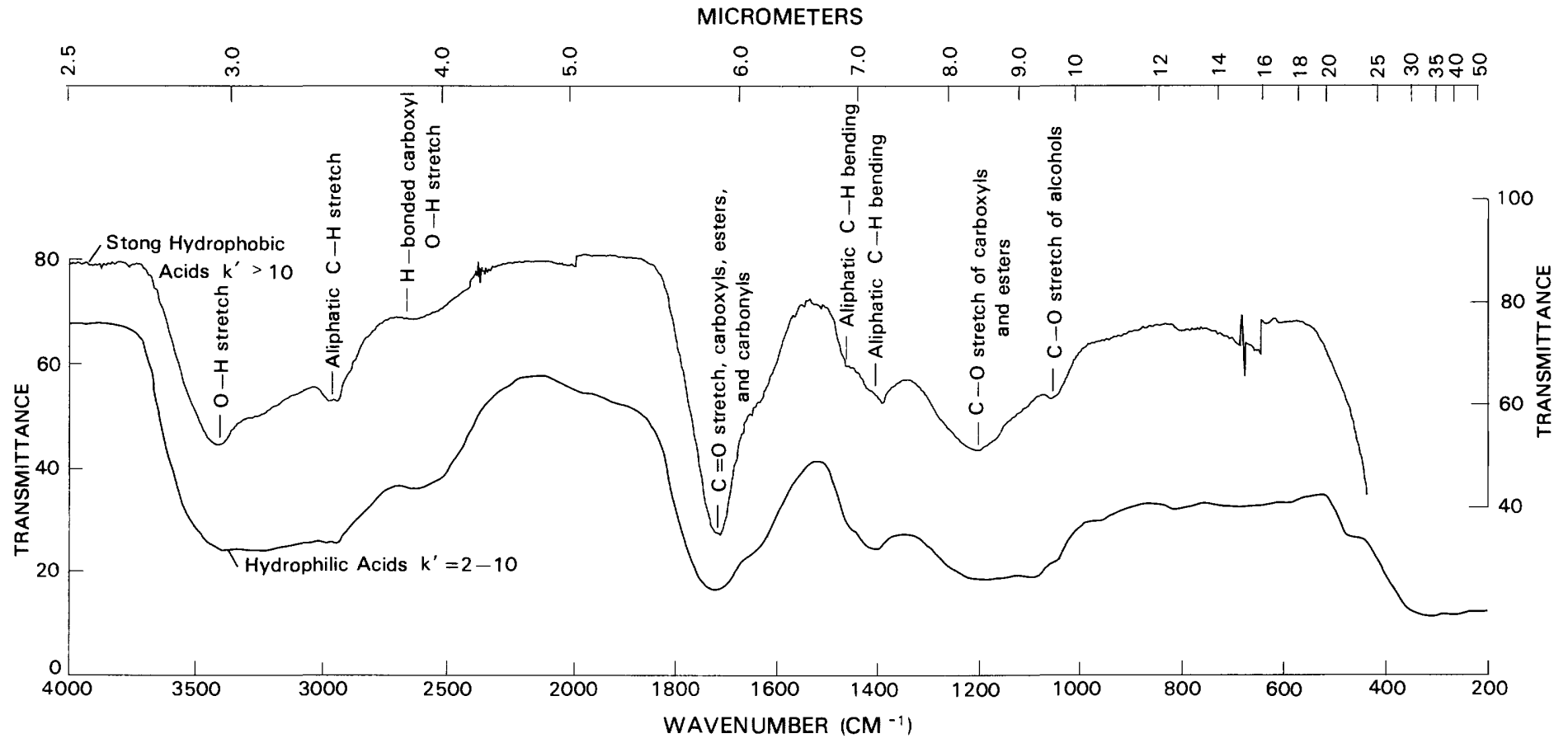

FIGURE 34.- Infrared spectra of strong hydrophobic- and hydrophilic-acid no. 1 fractions of the White River; river sampled September 1981.

humic-acid no. 2 is evidenced by the $\mathrm{C}-\mathrm{O}$ alcohol band at $\mid$ which is substantiated by the large nitrogen concentra$1,040 \mathrm{~cm}^{-1}$. The amide I and II bands in humic-acid no. 2 tion (5.31 percent) in this fraction. In figure 34 , the are indicative of the proteinaceous character of this fraction, hydrophilic-acid fraction differs from the hydrophobic- 
acid fraction in the greater intensity of the broad $\mathrm{OH}$ band from 3,700 to $2,300 \mathrm{~cm}$ and greater band broadening due to hydrogen bonding. Both of these differences result from the greater hydrophilic or hydroxylic character of the hydrophilic-acid fraction.

Comparison of the infrared spectrum of the strong hydrophobic-acid fraction from the White River (fig. 34) with the infrared spectrum of the well D-8 organic acids (fig. 31) shows no differences between these two samples except for the silica bands in the well D-8 sample. However, the other chemical and proton NMR data indicate major differences, which demonstrate that infrared spectroscopy can be nondefinitive in certain instances. Much of the September 1981 sample was used to develop more definitive methods based on functional-group derivatization and proton NMR spectroscopy. This newly developed method then was applied to the well D-8 sample discussed previously, and the June 1982 sample from the White River to be discussed in the following paragraphs.

The strong hydrophobic- and hydrophilic-acid fractions of the June 1982 sample were concentrated and acidified to generate two humic-acid samples similar to the September 1981 sample. However, no humic acid formed during the concentration step and a humic-acid precipitate comprising only $55 \mathrm{mg}$ of carbon formed during the acidification step. Only 1.8 percent of the total isolated carbon in the June 1982 sample was humic acid, whereas humic acid in the September 1981 sample comprised 14.8 percent of the isolated carbon.

In the September 1981 sample, the acids fractionated according to their column capacity-factor $\left(k^{\prime}\right)$ affinities for XAD-8 resin showed a bimodal distribution with $k^{\prime}$ with the valley between the two distributions occurring near $k^{\prime}=2$. Each distribution has distinctive chemical properties. Therefore, to sample these two distributions for the June 1982 sample, the combined strong hydrophobic- and hydrophilic-acid fraction was subdivided by column chromatography on XAD-8 resin so that the strong hydrophobic acids were defined for $k^{\prime} / 2.6$ and the hydrophilic acids were defined as $k^{\prime}(2.6$. Chemical data characterizing the various fractions of the June 1982 sample are shown in table 23. The humic-acid fraction was not characterized chemically because of lack of sufficient material, and the hydrophilic-base fraction was found to be almost identical to the weak hydrophobicacid fraction by chromatography on ion-exchange cellulose; therefore, it was not chemically characterized as a unique fraction.

Most of the material isolated in the June 1982 sample resides in the hydrophobic-acid fraction (table 23), which is in contrast to the September 1981 sample that had a much greater percentage of hydrophilic acids (table 22). The hydrophilic-acid fraction of the June 1982 sample is characterized by its very large acid concentration. Assum-

TABLE 23. - Chemical and elemental analyses of organic-solute
fractions isolated from the White River, sampled June 1982
[Data in percent except as indicated: mg C, milligrams of carbon;
meq/g C, milliequivalents per gram carbon]

${ }^{1}$ Isolated as sodium salts.

ing that carboxyl-group concentration is equivalent to the strong-acid titration data for the hydrophilic-acid fractions, 40.2 percent of the carbons are carboxyl carbons and 52.6 percent of the oxygens are carboxyl oxygens. The strong hydrophobic-acid and weak hydrophobicacid fractions have progressively less acid and oxygen concentrations and greater hydrogen concentrations. The index of hydrogen deficiency per carbon after correction for carboxyl-acid concentration shows a tendency for increasing unsaturation when going from hydrophilic acids to strong hydrophobic acids to weak hydrophobic acids.

The infrared spectra of the four acid fractions from the June 1982 sample are shown in figure 35; the proton NMR spectra are shown in figure 36 . Structural- and functional-group assignments are noted on the spectra in figures 35 and 36 . The proton NMR spectra in figure 36 give more definitive quantitative information than the infrared spectra in figure 35 , but the infrared spectra give qualitative information on silica and certain functional groups that is not obtainable by proton NMR. By using the proton NMR spectral data in figure 36 and the chemical and elemental analyses in table 23 , quantitative structural- and functional-group information for three of the organic-acid fractions from the June 1982 sampling of the White River is shown in table 24. Methods of data acquisition and interpretation were the same as 


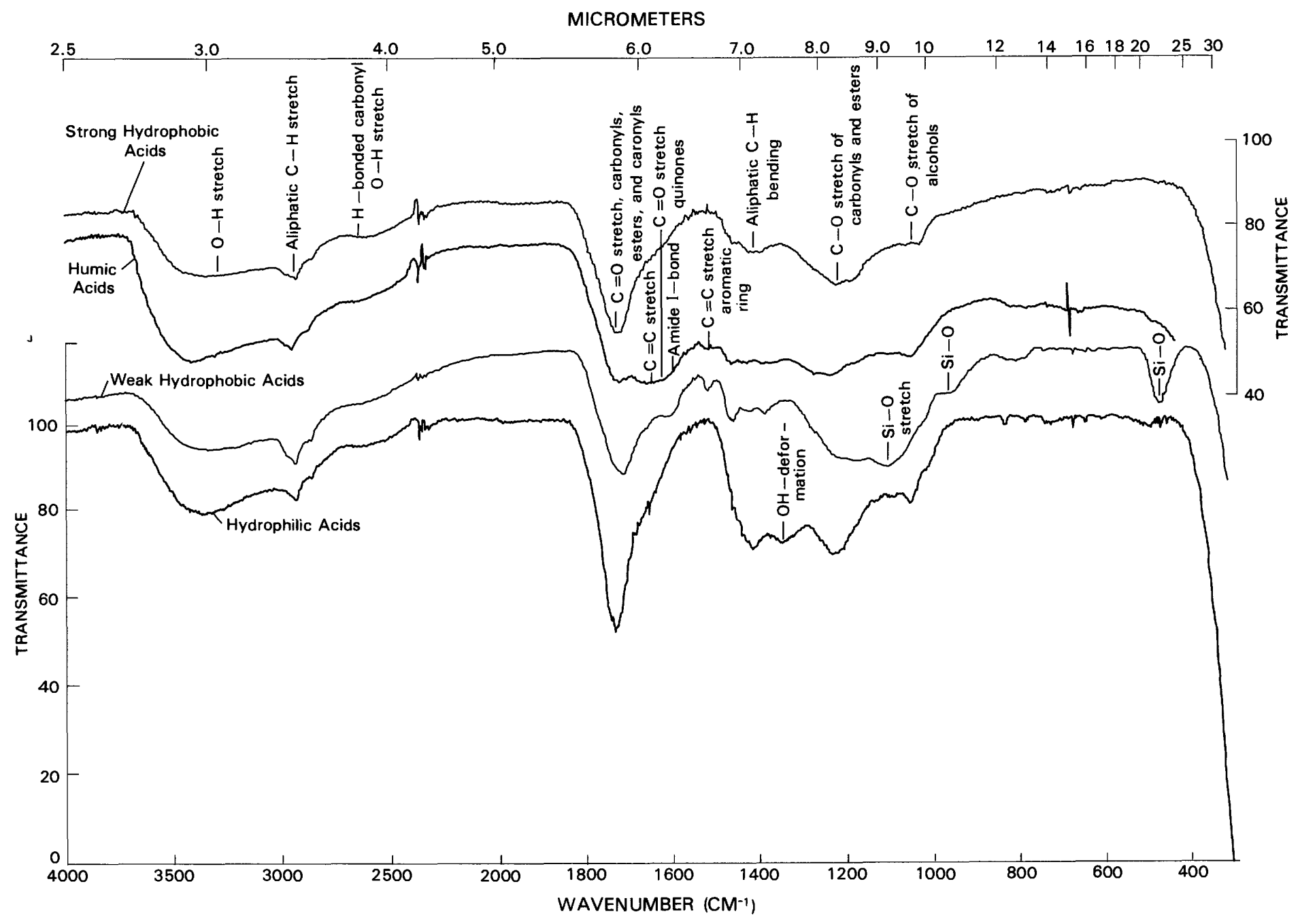

FIGURE 35.-Infrared spectra of acid fractions of the White River; river sampled June 1982.

described previously for the well D-8 organic acids shown in table 17.

Each of the organic-solute fractions isolated from the White River during the June 1982 sample have unique chemical and physical characteristics. The model for the strong hydrophobic-acid fraction, which constitutes the largest solute fraction ( 85 percent of carbon isolated), only can be described generally as an aquatic fulvic acid. Specific structures for any soil or aquatic fulvic acids have not been clarified yet. The White River fulvic acid is characterized by having a typical carboxyl-group concentration, typical aliphatic- to aromatic-hydrocarbon ratio, significant ester and ether concentration, and a minimal hydroxyl-group concentration. Most of the original free hydroxyl groups of precursors of this fulvic acid must have been converted to ester and ether groups through humification processes.

The weak hydrophobic-acid fraction can be regarded as the natural detergent fraction in the White River. Its significant isolated aliphatic-hydrocarbon concentration, as shown in the proton NMR, produces surface activity that causes foaming in the water. This fraction also has a minimal carboxylic-acid concentration, a moderate aromatic concentration, and a large silica concentration. The silica conjugated to this fraction is responsible for its weak-acid characteristics, which enable its separation from the strong hydrophobic acids.

The hydrophilic acids have very significant carboxylgroup acidity and a moderate hydroxyl-group concentration as evidenced by bands at 1,350 and $1,050 \mathrm{~cm}^{-1}$ in the infrared spectra. This fraction is almost entirely aliphatic in nature, and almost every carbon is attached to an oxygen substituent. The significant nitrogen concentration in this fraction is unusual, and the infrared spectra do not show evidence of amide bands indicative of proteins. Nitrogen in this fraction may reside as Shiff base linkages resulting from sugar-amine condensation reactions. The sugar-amine condensation, also called the browning 


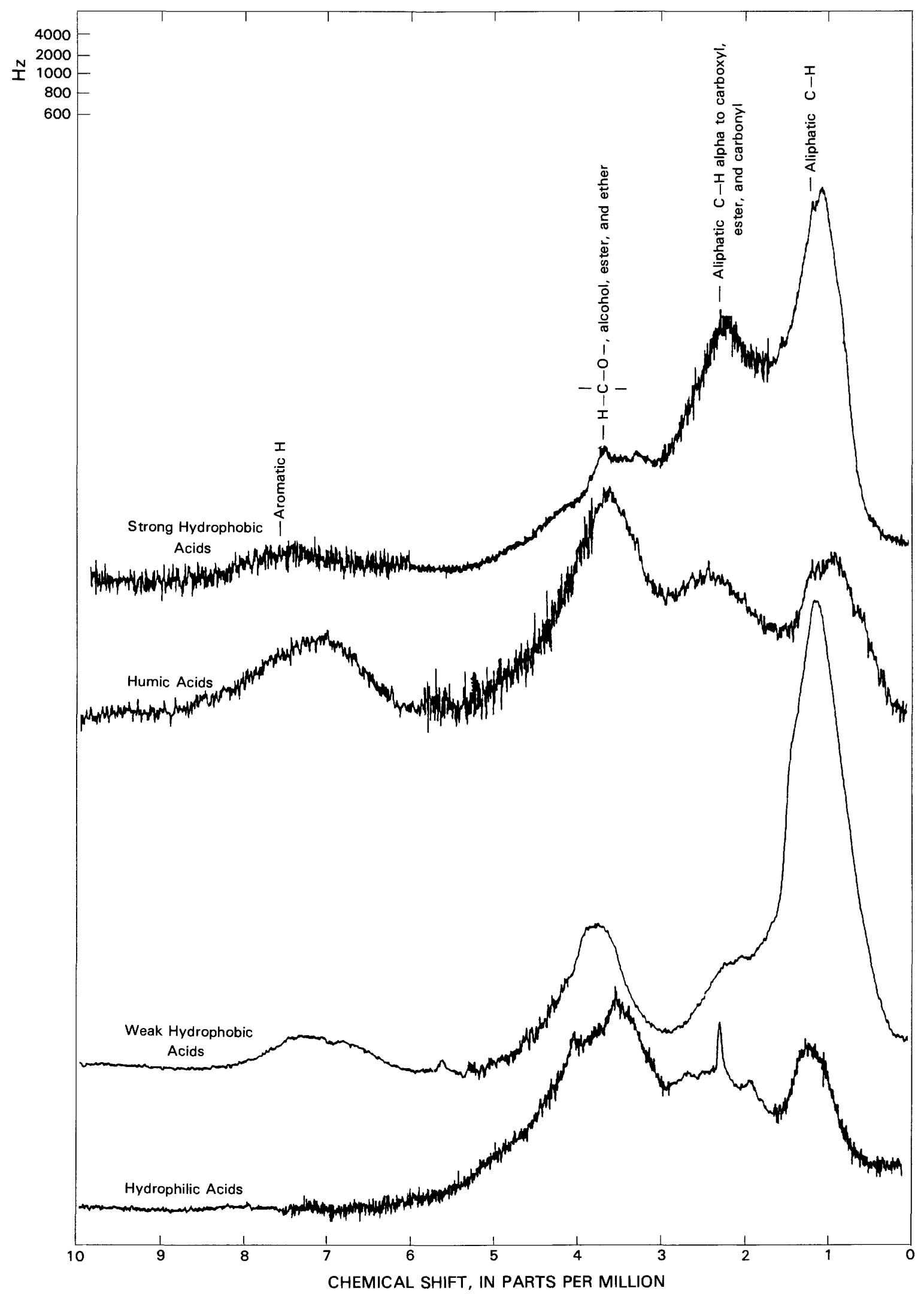

FIGURE 36. - Proton nuclear magnetic resonance (NMR) spectra of acid fractions of the White River; river sampled June 1982. 
TABLE 24.-Quantitative organic structural- and functionalgroup information on organic-acid fractions from the White River, sampled June 1978

$$
\text { [H, hydrogen: O. oxygen] }
$$

\begin{tabular}{|c|c|c|c|}
\hline $\begin{array}{l}\text { Structural- or } \\
\text { functional-group } \\
\text { unit }\end{array}$ & $\begin{array}{c}\text { Strung } \\
\text { hydrophobic } \\
\text { acids }\end{array}$ & $\begin{array}{c}\text { Weak } \\
\text { hydrophobic } \\
\text { acids }\end{array}$ & $\begin{array}{l}\text { Hydiophilic } \\
\text { acids }\end{array}$ \\
\hline
\end{tabular}

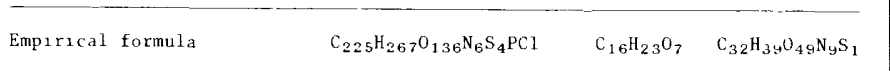

Hydrogen distribution

Strong-acid (carboxyl)

hydrogen .

Weak-acid (phenolic,

enolic, silicic acid)

hydrogen.

Isolated aliphatic-

hydrocarbon hydrogen.

Aliphatic hydrogen on carbons

dipha to carbonyl, carboxyl,

and ester groups.

Aliphatıc hydrogen on carbons

attached to hydroxyl, ester,

and ether oxygen.

Aromatic hydrogen.

oxygen distribution

Carboxyl oxygen.

Carbony1 oxygen.

Hydroxyl oxygen.

Ester oxygen.

Ether oxygen.

Number of rings or double bonds

Carboxyl oxygen double bonds.

Carbonyl oxygen double bonds.

Ester oxygen double bonds.

Aromatic rings and double bonds

associated with aromatic

hydrogen.

Unaccounted rings and double

bonds.

Ratio of unaccounted rings and

double bonds with structural

carbon (excluding carboxyl

carbon). responsible for the precipitation of this fraction on acidification.

\section{CONCLUSIONS}

Natural organic solutes characterized by this study were very different from organic contaminants produced by the oil-shale retorting process. Organic contaminants from oil-shale processing listed in table 3 are all low molecular-weight monomeric compounds, whereas natural organic solutes are complex heterogeneous polymers of biological origin. Assays for aromatic amines of natural origin in surface and ground waters by the identical method used for oil-shale retort wastewaters failed to find any simple aromatic amines at concentrations near $1 \mu \mathrm{g} / \mathrm{L}$. Concentrations of DOC in natural waters are two to four orders of magnitude less than DOC in retort wastewaters. It is unlikely that many of the monomeric organic solutes in retort wastewaters will persist for a decade if discharged into the White River; they will be degraded through biological, chemical, and photolytic processes, and the residual fragments will be incorporated into humic-type substances. The aromatic-amine fraction, which is the most resistant to biological degradation, will predominantly partition onto and be transported by sediment.

Natural organic solutes in ground water of the Rio Blanco well D-8 can be distinguished from natural organic solutes in the White River by the absence of the peak at $3.8 \mathrm{ppm}$ in the proton NMR spectrum of well D-8 organic acids. This peak is indicative of alcohols, esters, and ethers, which for unknown reasons are not present in the ground-water sample. The ground-water organic acids also have a smaller aromatic concentration than the surface-water organic acids.

Seasonal and flow variations in composition of White River organic solutes were distinguished mainly by the greater humic-acid and hydrophilic-acid concentrations during the fall sample at low flow. These two fractions had the greatest hydroxyl and carbohydrate concentrations, and their abundance in the fall is believed to be related to the primary productivity from phytoplankton in the river at low flow when suspended sediment concentrations are minimal and allothonous inputs of organic constitutents are minimized. In the spring during high flow, organic inputs to the river are of allocthonous origin, and these organic constituents are already partly decayed, which decreases their hydroxyl and resulting humic-acid and hydrophilic-acid percentages. The hydrophilic-acid fraction probably is degraded rapidly in the river, and its percentage may be more related to competing rates of input and decay than to total mass of material input in this fraction. ppm in the proton NMR spectra. Molecular interactions between these hydrogen-bonding groups probably are reaction, is one of the major theories of humic-substance formation as summarized by Stevenson (1982). Thu hydrophilic acids can be described as a mixtu amide nitrogen concentration.

The humic-acid fraction, which only constituted a trace of the June 1982 sample, was characterized by its significant aromatic-hydrogen concentration as shown by the proton NMR (fig. 36). It also contained many hydrogenbonding groups as evidenced by the major peak at 3.8

(1) 


\section{SUMMARY}

Onsite processing of oil shale in the Green River Formation generates liquid, solid, and gaseous wastes, which may impact the quantity and quality of local water resources. Liquid and gaseous wastes from oil-shale retorting are similar to coal-conversion and petroleumrefining wastes, but are different in the significantly greater levels of nitrogenous waste constituents produced. Solid spend-shale wastes also are different compared to coal-conversion processes and petroleum-refining operations in the vast quantities produced and their chemical and physical properties that are dependent both on the properties of the parent oil shale and the nature of the retorting process. The characteristics of water and sediment derived from the Green River Formation are different compared to most other hydrologies and geologies associated with fossil-fuel productions because of the unique assemblage of minerals in the alkaline lacustrine deposit of the Green River Formation.

Hydrophobic organic-waste constituents (table 3 ) have a much greater tendency to be sorbed on aquifer solids or sediments in surface waters than hydrophilic constituents that are likely to be transported as solutes. Soils developed from sediments of the Green River and overlying Uinta Formations have a relatively large capacity to immobilize hydrophobic organic-waste constitutents by sorptive processes, and the majority of the hydrophilic-waste constituents are fatty acids that are readily biodegradable. Application of concentrated retort wastewater on soil adversely affects soil structure and extracts soil organic matter into solution. Immobilization of wastewaters by codisposal with low-temperature retorted spent shale is especially attractive because of its excellent sorbent tendencies for organic constituents. Organic-waste compounds that are not readily sorbed or biodegraded include thiocyanate, acetonitrile, and oxygenated nitrogen heterocycles; however, these compounds are not known to be especially toxic or mutagenic. Thiocyanate was found to be useful as a conservative organic-solute tracer for retort-wastewater presence in ground waters.

Organic constituents in wastewaters, consisting mostly of small molecular-weight monomeric solutes, are readily distinguished by chemical analyses from large molecular-weight polymeric organic constituents found in native surface and ground waters. Natural organicsolute concentrations in surface and ground waters (in this study), with the exception of very alkaline trona waters, generally are less than the concentrations of organic constituents found in sediments of the Green River Formation.

Retorting wastes can be treated and disposed of in surface-retorting processes much more readily than with in-situ retorting processes because of the lack of accessibility for waste treatment with in-situ processes. True in-situ retorting processes have the greatest potential for ground-water contamination, but these processes are unlikely to become viable technologies in the near future because of fundamental limitations in the fracturing process prior to retorting. Modified in-situ retorting processes have succeeded in managing waste emissions and preventing ground-water contamination during retorting, but there is a significant potential for groundwater contamination after retort abandonment.

Waste-treatment technologies, previously developed by petroleum-refining and coal-conversion technologies, should be adaptable to treatment of liquid and gaseous oil-shale retorting wastes. Two of the most hazardous waste constituents, ammonia and sulfides, have the potential to be recovered by treatment processes and sold as ammonium salts and elemental sulfur. Disposal, compaction, and revegetation of spent shale is the largest waste problem facing the shale-oil industry, but spent shale also has been proposed and tested as a source of alumina, as cement, and as a sorbent for acid-retort gases and wastewaters.

Aromatic amines are the organic-compound group most likely to cause problems in retorting wastes. Aesthetic problems resulting from their noxious odors probably will outweigh their toxicological and mildly mutagenic properties. It is unlikely that aromatic amines will persist as solutes in water because of their tendency for sorption, but their volatilization from sediments and spent shale may cause long-term odor problems. Thiocyanate and phenols in retort wastes will need to be considered when designing treatment processes. Chlorination should not be used when these compounds are present because toxic cyanogen chloride and chlorinated phenols will be produced with chlorine treatment.

The research in this report concerned wastes produced by experimental and pilot plant oil-shale retorting processes and the results may be limited in their predictive capabilities by the experimental nature, long-term storage of samples before analysis, and small scale of the retorting process. Ground-water hydraulic studies need to go hand in hand with water-quality studies. As the oil-shale industry scales up its operations to commercial level production of shale oil, there needs to be continued studies of water-quality effects associated with shale-oil production to refine predictive capabilities for better water-resource planning. The retention and degradation of waste organic constituents on surface sediments needs the most attention at this point in time. However, enough presently is known about retorting processes, and the nature, behavior, and environmental effects of retort wastes and waste-treatment processes to select those technologies that result in a self-sustaining shale-oil industry with minimal long-term environmental effects. 


\section{REFERENCES}

American Society for Testing and Materials, 1982, Annual book of ASTM standards, part 31: "Water" Philadelphia, Pa.. D-3987.

Barry, H.J., 1981, A review of the State policies and concerns about rapid, federally assisted oil shale industrialization: Oil Shale Symposium, 14th, Golden, Colo., 1981, Proceedings, p. 301-320.

Bradley, W.H., 1930, The varves and climate of the Green River epoch: U.S. Geological Survey Professional Paper 158-E, p. $87-110$.

Caine, J.M., 1982, Sources of dissolved humic substances of a subalpine bog in the Boulder watershed, Colorado: Boulder, Colo., University of Colorado, unpublished M.S. thesis, 85 p.

Cowling, S.W., 1979, Evaluation of processed oil shale and sediments as sorbents for waste organic solutes, produced by in situ oil shale retorting: Golden, Colo., Colorado School of Mines, unpublished M.S. thesis, $125 \mathrm{p}$.

Crawford, K.W., Prien, C.H., Baboolal, L.B., Shih, C.C., and Lee, A.A., 1977, A preliminary assessment of the environmental impacts from oil shale developments: Environmental Protection Agency Interagency Energy-Environment Research and Development Report no. 600/7-77-069, 174 p.

Dinneen. G.U., 1976, Retorting technology of oil shale, in Yen, T.F., and Chilingarian, G.V., eds., Oil shale series no. 5 in developments in petroleum science: Amsterdam, Elsevier Scientific Publishing Company, p. 181-197.

Donnell, J.R., and Blair, R.W., Jr., 1970, Resource appraisal of three rich oil-shale zones in the Green River Formation, Piceance Creek Basin, Colorado: Quarterly of the Colorado School of Mines, v. 65 , no. 4 , p. 73-87.

Duncan, D.C., and Swanson, V.E., 1965, Organic-rich shale of the United States and world land areas: U.S. Geological Survey Circular 523, 30 p.

El-Nahel, M.A., and Wittig, L.D., 1973, Cation exchange behavior of a zeolitic sodic soil: Soil Science Society of America Proceedings, v. 37, p. 956-958.

Farrier, D.S., Poulson, R.E., Skinner, Q.D., Adams, J.C., and Bower, J.P., 1977, Acquisition, processing, and storage for environmental research of aqueous effluents from in situ oil shale processing: Pacific Chemical Engineering Congress, 2nd, Denver, Colo., 1977, Proceedings, v. 2, p. 1031-1035.

Felix, W.D., Farrier, D.S., and Poulson, R.E., 1977, High performance liquid chromatographic characterization of oil shale retort waters: Pacific Chemical Engineering Congress, 2nd, Denver, Colo., 1977, Proceedings, v. 1, p. 480-485.

Fox, J.P., 1978, The partitioning of major and minor elements during simulated in situ oil shale retorting: Berkeley, Calif., University of California, Ph. D. dissertation, $441 \mathrm{p}$.

Fox, J.P., Farrier, D.S., and Poulson, R.E., 1978, Chemical characterization and analytical considerations for an in situ oil shale process water: Laramie, Wyo., Laramie Energy Technology Center Report of Investigations 78/7, $47 \mathrm{p}$.

Fox, J.P., Jackson, D.E., and Sakaji, R.H., 1980, Potential uses of spent shale in the treatment of oil shale retort waters: Oil Shale Symposium, 13th, Golden, Colo., 1980, Proceedings, p. $311-320$.

Gauger, W.K., 1981, Dissolved organic carbon degradation in oil shale retort waters by indigenous bacteria: Laramie, Wyo., University of Wyoming, unpublished $\mathrm{Ph}$. D. dissertation, $103 \mathrm{p}$.

Hendrickson, T.A., compiler, 1975, Synthetic fuels data handbook: Denver, Colo., Cameron Engineers, Inc., 308 p.

Huggins, C.W., and Green, T.E., 1973, Thermal decomposition of Dawsonite: American Mineralogist, v. 58, p. 548-550.

Jackson, L.P., and Jackson, K.F., 1983, The codisposal of retorted shale and process waters - Effect on shale leachate composition: Oil Shale Symposium, 15th, Golden, Colo., 1983, Proceedings, p. 505-515.

Jackson, L.P., Poulson, R.E., Spedding, T.J., Phillips, T.E., and Jensen, H.B., 1975, Characteristics and possible roles of various waters significant to in situ oil shale processing: Quarterly of the Colorado School of Mines, v. 70, p. 105-134.

Jones, B.M., Sakaji, R.H., and Daughton, C.G., 1983, Physiochemical treatment methods for oil shale wastewater-Evaluation as aids to biooxidation: Oil Shale Symposium, 15th, Golden, Colo., 1983, Proceedings, p. 581-597.

Kedeti, G., and Lederer, W.H., 1974, Handbook of micro-methods for the biological sciences: New York, Van Nostrand and Reinhold, p. 51, 96-97.

Koller, K.L., and Dorn, H.C., 1982, Acid-catalyzed reactions of 2, $2,2,-$ trifluorodiazoethane for analysis of functional groups by $F-19$ nuclear magnetic resonance spectrometry: Analytical Chemistry, v. 54, p. 529-533.

Krause, J.B., and McLean, W.J., 1980, Mineralogy-groundwater quality-A study of in situ retorted oil shale: Ada, Okla, Robert S. Kerr Environmental Research Laboratory, Environmental Protection Agency Research Grant no. R-804162 Final Report, 85 p.

Leenheer, J.A., 1980, Study of sorption of complex organic solute mixtures on sediment by dissolved organic carbon fractionation analysis, in Baker, R.A., ed., Contaminants and sediments: Ann Arbor, Mich., Ann Arbor Science, v. 2, p. 267-278.

1981, Comprehensive approach to preparative isolation and fractionation of dissolved organic carbon from natural waters and wastewaters: Environmental Science and Technology, v. 15, p. $578-587$.

Leenheer, J.A., and Huffman, E.W.D., Jr., 1976, Classification of organic solutes in water by using macroreticular resins: U.S. Geological Survey Journal of Research, v. 4, no. 6, p. 737-751.

1979 (1982), Analytical method for dissolved organic-carbon fractionation: U.S. Geological Survey Water-Resources Investigations $79-4,20 \mathrm{p}$.

Leenheer, J.A., and Moe, P.G., 1969, Separation and functional group analysis of soil organic matter: Soil Science Society of America Proceedings, v. 33, p. 267-269.

Leenheer, J.A., and Noyes, T.I., 1985, A filtration and column adsorption system for onsite concentration and fractionation of organic substances from large volumes of water: U.S. Geological Survey Water-Supply Paper 2230, 16 p.

Leenheer, J.A., Noyes, T.I., and Stuber, H.A., 1982, Determination of polar organic solutes in oil-shale retort water: Environmental Science and Technology, v. 16, p. 714-722.

Leenheer, J.A., and Stuber, H.A., 1981, Migration through soil of organic solutes in an oil shale process water: Environmental Science and Technology, v. 15, p. 1467-1475.

Leenheer, J.A., Stuber, H.A., and Noyes, T.I., 1981, Chemical and physical interactions of an in situ oil shale retorting experiment: Oil Shale Symposium, 14th, Golden, Colo., 1981, Proceedings, p. 357-375.

Long, A., Jr., Merriam, N.W., and Mones, C.J., 1977, Evaluation of Rock Springs site 9 in situ oil shale retorting experiment: Oil Shale Symposium, 10th, Golden, Colo., 1977, Proceedings, p. 120-135.

Pitter, P., 1975, Determination of biological degradability of organic substances: Water-Resources Research, v. 10, p. 231-235.

Probstein, R.F., and Gold, H., 1978, Water in synthetic fuel production - The technology and alternatives: Cambridge, Mass., Massachusetts Institute of Technology Press, $296 \mathrm{p}$. 
Raphaelian, L.A., and Harrison, W., 1981, Organic constituents in process water from the in situ retorting of oil shale kerogen: Argonne, Ill., Occidental Oil Shale, Inc., Logan Wash No. 6 Retort Experiment, Argonne National Laboratory Report AN4-PAG-5, $36 \mathrm{p}$.

Rickert. D.A., Ulman, W.J., and Hampton, E.R., eds., 1979, Synthetic fuels development-Earth-science considerations: U.S. Geological Survey special publication, 45 p. [Available from U.S. Government Printing Office, Washington, D.C.]

Riley, R.G., Garland, T.R., Shiosaki, K., Mann, D.C., and Wilding, R., 1981, Alkylpyridines in surface waters, ground waters, and subsoils of a drainage located adjacent to an oil shale facility: Environmental Science and Technology, v. 15, p. 697-701.

Robinson, T., 1980, The organic constituents of higher plants (4th ed.): North Amherst, Mass., Cordus Press, p. 31.

Robinson. W.E., 1969, Isolation procedures for kerogens and associated soluble organic materials, in Eglinton, G., and Murphy, M.T.J., eds., Organic geochemistry-Methods and results: New York, Springer-Verlag, p. 181-195.

Robson, S.G., and Saulnier, G.J., Jr., 1980, Hydrogeochemistry and simulated solute transport, Piceance Basin, northwestern Colorado: U.S. Geological Survey Open-File Report 80-72, $95 \mathrm{p}$.

Saxby, J.D., 1976, Chemical separation and characterization of kerogen from oil shale, in Yen, T.F., and Chilingarian, G.V., eds., Oil shale series no. 5 in developments in petroleum science: Amsterdam, Elsevier Scientific Publishing Company, p. 103-122.

Sladex, T.A.. Poulton, P.L., Davis, W.E., and Robinson, P.A., 1980, A technology assessment of oil shale development: Oil Shale Symposium. 13th, Golden, Colo., 1980, Proceedings, p. 1-25.

Slawson, G.C., Jr., ed., 1980, Monitoring groundwater quality The impact of oil shale retorting: U.S. Environmental Protection Agency Interagency Energy-Environmental Research and Development Report no. 500/7-80-132, 279 p.

Stanwood, R.M., Wallace, W.A., and Gaudette, J.J., 1980, The impact of RCRA (PL94-580) on oil shale development: Oil Shale Symposium, 13th, Golden. Colo., 1980, Proceedings, p. 221-225.

Stevenson, F.J., 1982, Humus chemistry: New York, Wiley-
Interscience, p. 216-218.

Stuber, H.A., and Leenheer, J.., 1978a, Fractionation of organic solutes in oil shale retort waters for sorption studies on processed shale: American Chemical Society Division of Fuel Chemistry Meeting, Anaheim, Calif., 1978, Reprints of papers, v. 23, p. 165-174.

1978 b, Assessment of a resin based fractionation procedure for monitoring organic solutes from oil shale retorting wastes, in Everett, L.G., and Schmidt, K.D., eds., Establishment of water quality monitoring programs: American Water Resources Association Symposium, San Francisco, 1978, Proceedings, p. 266-272.

Stuber, H.A., Leenheer, J.A., and Farrier, D.S., 1978, Inorganic sulfur species in waste waters from in situ oil shale processing: Journal of Environmental Science and Health, V-A13, p. $663-675$.

Thurman, E.M., and Malcolm, R.L., 1983, Structural study of humic substances - New approaches and method, chap. 1, in Christman, R.F., and Gjessing, E.T., eds., Terrestrial and aquatic humic substances: Ann Arbor, Mich., Ann Arbor Science, p. 1-35.

Torpy, M.F., Luthy, R.G., and Raphaelian, L.A., 1982, Activated sludge treatment and organic characterization of oil shale retort water: Oil Shale Symposium, 15th, Golden, Colo., 1982, Proceedings, p. 487-493.

U.S. Environmental Protection Agency, 1980, Hazardous waste management system - Identification and listing of hazardous wastes: Federal Register, v. 45, p. 33122-33130.

Wallace, J.R., Culbertson, W.J., Habenicht. C.H., and Shaffron, M., 1981. A transportable steam stripper for the pilot scale treatment of oil shale wastewaters-Design, field testing, and chemical analysis: Oil Shale Symposium, 14th, Golden, Colo., 1981, Proceedings, p. 330-336.

Weeks, J.B., Leavesley, G.H., Welder, F.A., and Saulnier, G.J., Jr., 1974, Simulated effects of oil-shale development on the hydrology of Piceance Basin, Colorado: U.S. Geological Survey Professional Paper 908, 84 p.

Woodward-Clyde Consultants, 1978, Soil survey including soil analysis and maps, near Rock Springs, Wyoming: Denver, Colo., 36 p.

Yen, T.F., ed., 1976, Science and technology of oil shale: Ann Arbor, Mich., Ann Arbor Science, p. 193-203. 